

$$
-8
$$
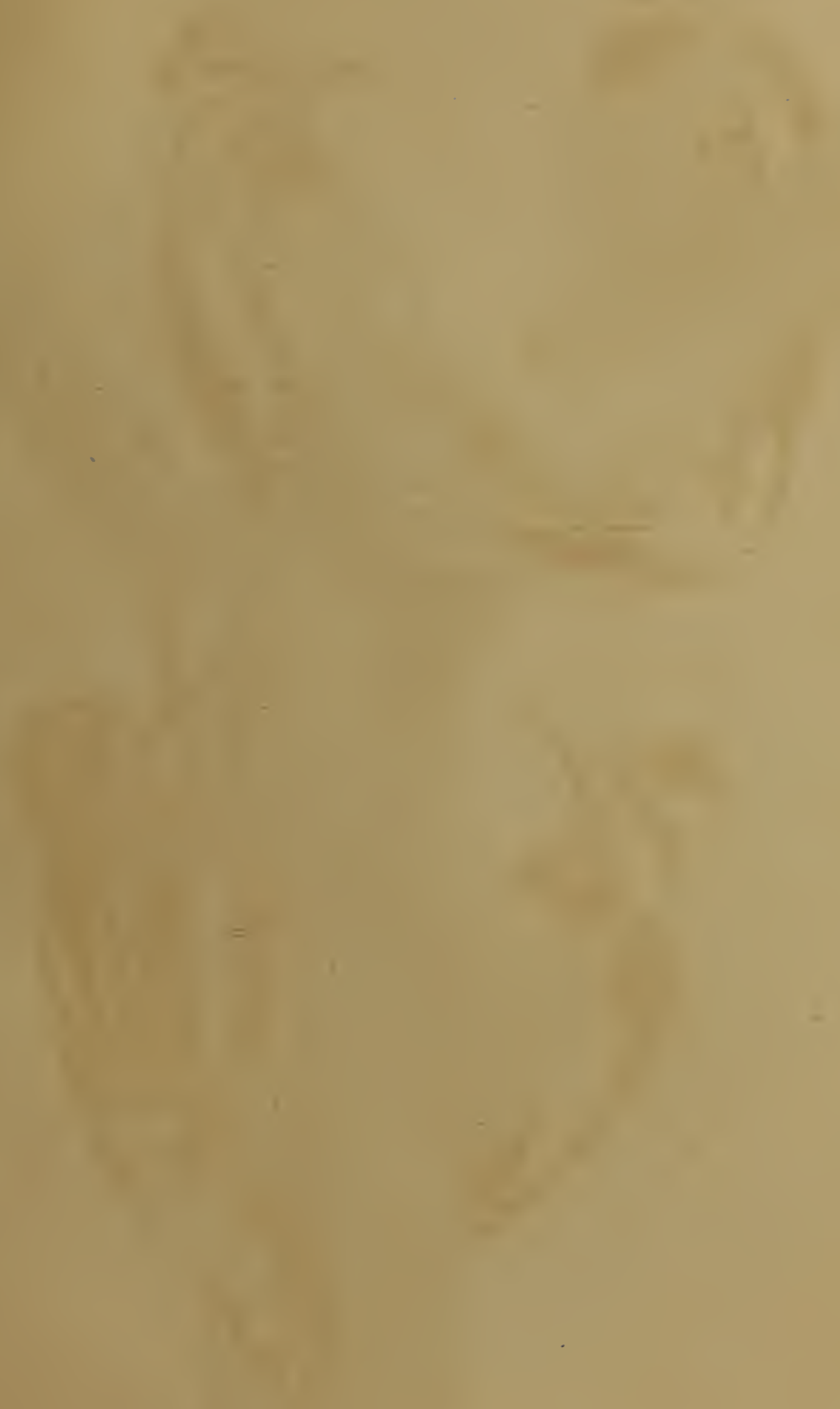


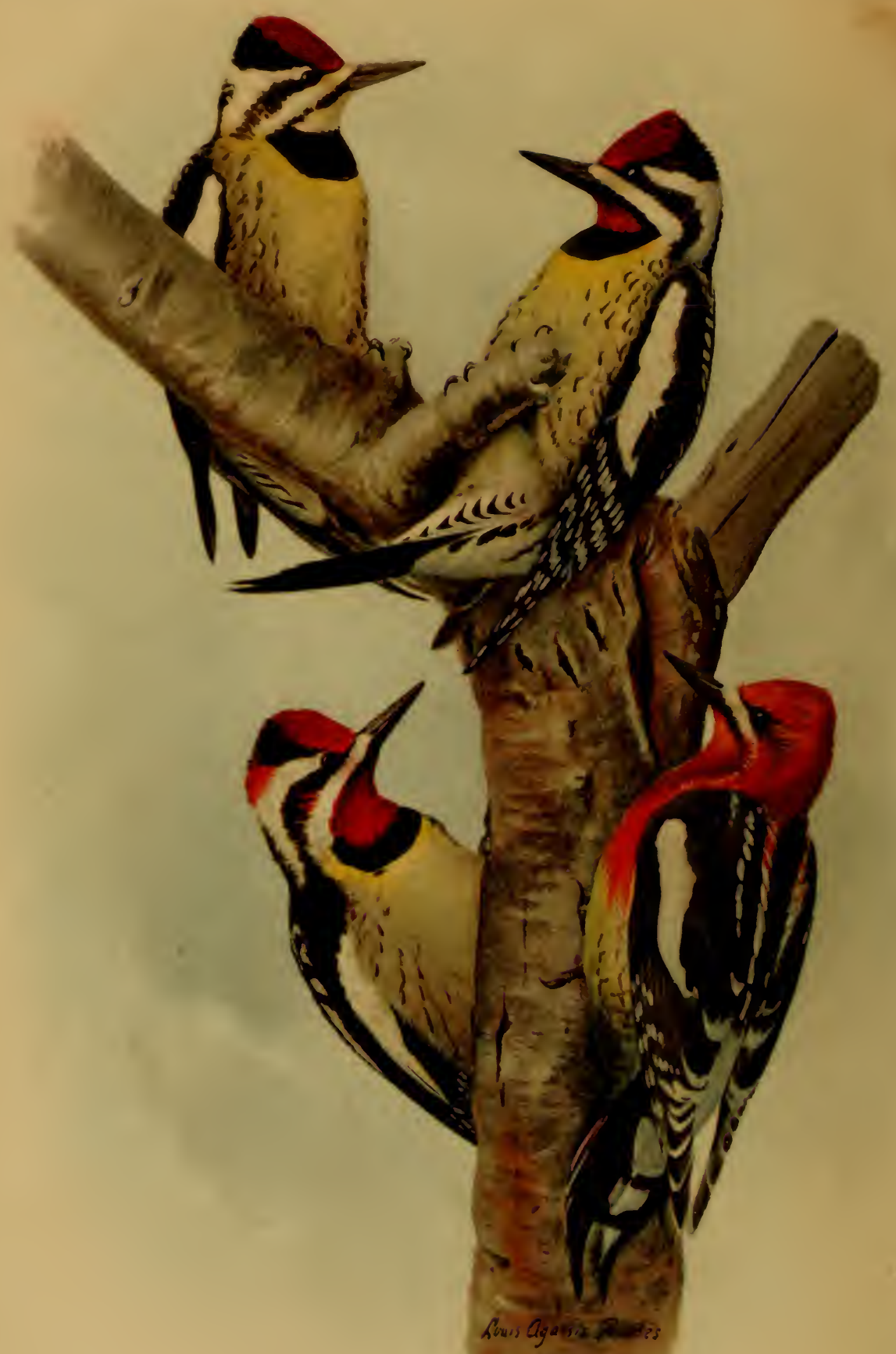

YELLOW-BELLIED, RED-NAPED, AND RED-BREASTED SAPSUCKERS.

[ 1 pher figures, yellow-bellied sapsuckers; lower left, red-naped sapsucker; lower right, red-breasted sapsucker.] 
U. S. DEPARTIENT OF AGRICULTURE BIOLOGICAL SURVEY-BULLETIN NO. 39

HENRY W. HENSHAW, Chief

\title{
WOODPECKERS IN RELATION TO TREES AND WOOD PRODUCTS
}

\author{
BY \\ W. L. McATEE \\ Assistant Biologist, Biological Survey
}

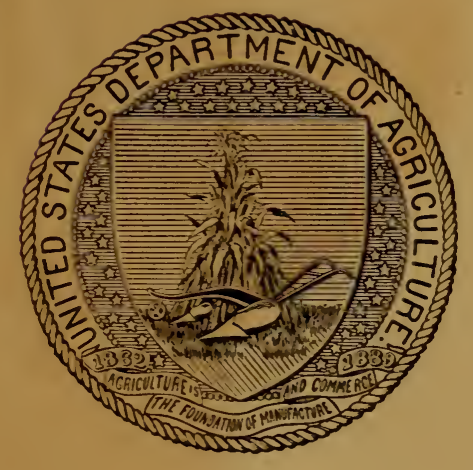

WASHINGTON

GOVERNMENT PRINTTNG OFFICE 



\section{LETTER OF TRANSMITTAL.}

\section{U. S. Departient of Agriculture,}

Bureat of Biological Surver,

Washington, D. C., May 24, 1911.

SIR: I have the honor to transmit herewith, for publication as Bulletin No. 39 of the Biological Surrey, a report on Woodpeckers in Relation to Trees and Wood Products, by W. L. McAtee, assistant, Biological Surrey. Woodpeckers as a family take high rank among our insectivorous birds, and being specially equipped to dig into wood for hidden larræ inaccessible to other birds aid materially in the conservation of our forests. Three members of the group, however, the only ones properly known as sapsuckers, are injurious, since their chief purpose in digging into trees is to secure the cambium and the sap for food. The holes they make also permit entrance of moisture, bacteria, and fungi which injure and sometimes destroy the tree. They also cause staining of the wood, seriously impairing its market value when converted into lumber. Altogether the damage done by sapsuckers in the United States amounts yearly to not less than $\$ 1,200,000$. This bulletin treats of the more strictly economic aspects of woodpecker work, and points out wherein the birds are beneficial and wherein injurious, and in the latter case suggests remedies.

Respectfully,

Hon. James WiLsox, Secretary of Agriculture.
Henry W. Hexshaw, Chief, Biological Survey. 



\section{CONTENTS}

Introduction

Damage by woodpeckers in general.............................

Damage to trees........................................... 7

Holes made in digging out insects....................... s 8

Excavation of nest and shelter cavities..................... 8

Attacks of tree enemies aided by woodpeckers................ 9

Compensation for injuries due to food and nest excavations........... 9

Damage to wocden posts and structures........................ $\quad 10$

Damage to telephone and telegraph poles.................. 10

Damage to fences and buildings......................... 13

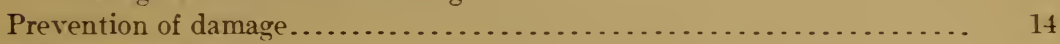

Damage by sapsuckers....................................... 16

Distribution and habits of sapsuckers........................ 16

Effects of sapsucker work on the external appearance of trees......... 18

Effects of sapsucker work on the health of trees.................. 20

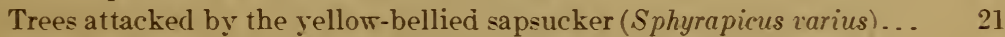

Trees attacked by the red-breasted sapsucker (Sphyrapicus ruber).... 50

Trees attacked by the Williamson sapsucker (Sphyrapicus thyroideus). . 53

Summary of injuries jeopardizing the vigor or life of trees........ 53

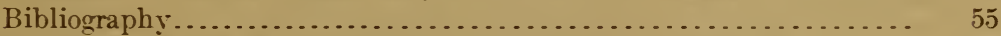

Effects of sapsucker work on lumber and finished wood products....... $\quad 56$

Introduction.............................................. 56

Woods in which blemishes or ornamental effects are known to result from sapsucker work................................ 62

Summary of blemishes and ornamental effects in lumber resulting from sapsucker work.............................. 89

Do other species of woodpeckers share the sapsuckers' habits?........ 91

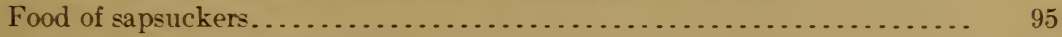

How to recognize sapsuckers.................................. 96

Defensive measures against sapsuckers........................ 96

General conclusions........................................... 98

\section{LL USTRATIONS.}

PLATES.

Plate I. Yellow-bellied, red-naped, and red-breasted sapsuckers..... Frontispiece

II. Williamson sapsucker ............................... 16

III. Work of pileated woodpecker; bleached walnut wood .......... 16

IV. Work of California woodpecker; swollen sapsucker girdles ......... 16

V. Work of flicker and sapsuckers ...................... 16

VI. Work of sapsucker on willow ....................... 28 
Plate VII. Work of sapsucker on white elm

VIII. Work of sapsucker on white elm and western hemlock

IX. Work of sapsucker on hickory, maple, basswood, and chestnut;

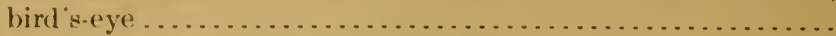

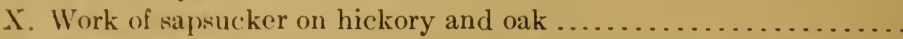

$\begin{array}{ll}\text { XI. Work of sapsucker on hickory, pitch pine, red cedar, and sassafras. . } & 72\end{array}$

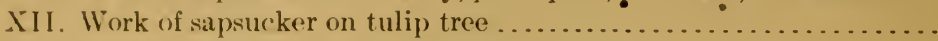

\section{TEXT FIGURES.}

Fia. 1. Homemade nest box for woodpeckers..................... 15

2. Longitudinal section of nest box shown in fig. $1 \ldots \ldots \ldots \ldots \ldots \ldots \ldots .15$

3. Spiny tongue of downy woodpecker..................... 17

4. Brushy tongue of sapsucker............................. 17

5. Sapsucker work on honey locust........................ 19

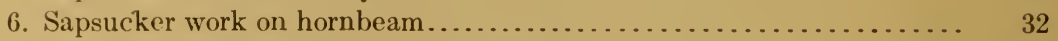

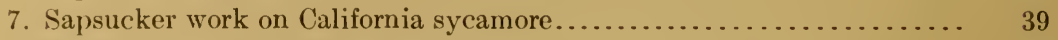

8. Sapsucker work on bitter cherry ....................... 43

9. Effects of sapsucker work on wood of sugar maple............. $\quad 59$

10. Effects of sapsucker work on wood of sugar maple.............. 60

11. Effects of sapsucker work on wood of long-leaf pine............... 63

12. Effects of sapsucker work on wood of bald cypress............. 64

13. Effects of sapsucker work on wood of bald cypress ............ 65

14. Effects of sapsucker work on wood of red cedar................. 66

15. Effects of sapsucker work on wood of red fir.................. $\quad 66$

16. Effects of sapsucker work on wood of black cottonwood........... 67

17. Effects of sapsucker work on wood of Carolina poplar.............. 68

18. Effects of sapsucker work on wood of black walnut............... 68

19. Effects of sapsucker work on wood of pecan.................. 71

20. Effects of sapsucker work on wood of big shellbark........... 72

21. Effects of sapsucker work on wood of hornbeam.............. 72

22. Effects of sapsucker work on wood of chestnut............... 73

23. Effects of sapsucker work on wood of black oak............... 74

24. Effects of sapsucker work on wood of cow oak................ $\quad 75$

25. Effects of sapsucker work on wood of white live oak........... 75

26. Effects of sapsucker work on wood of live oak................ $\quad 76$

27. Effects of sapsucker work on wood of shin oak............... 77

28. Effects of sapsucker work on wood of slippery elm.............. 78

29. Effects of sapsucker work on wood of hackberry.............. 78

30. Effects of sapsucker work on wood of red bay.................. $\quad 79$

31. Effects of sapsucker work on wood of California holly............. 81

32. Effects of sapsucker work on wood of honey locust............. 82

33. Effects of sapsucker work on wood of honey locust............. 83

34. Effects of sapsucker work on wood of holly ................ 84

35. Effects of sapsucker work on wood of basswood............... 85

36. Effects of sapsucker work on wood of flowering dogwood.......... 86

37. Effects of sapsucker work on wood of the tree huckleberry.......... 87

38. Yellow-bellied sapsucker.................................... 92

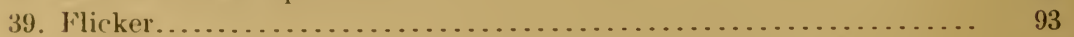

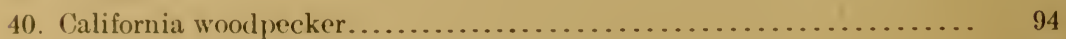

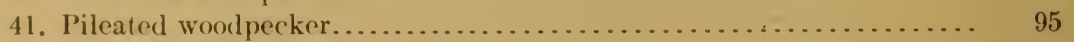

42. Hairy woodpecker................................ 96

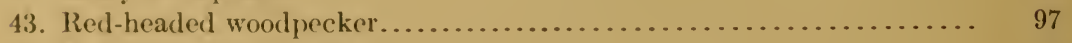

44. Red-bellied woolpecker.............................. 98 


\section{WOODPECKERS IN RELATION TO TREES AND WOOD PRODUCTS.}

\section{INTRODUCTION.}

Woodpeckers are peculiarly dependent upon trees, which furnish them food, shelter, and cradles for their young. No birds are more highly specialized nor more perfectly adapted to a particular mode of life than are most woodpeckers to arboreal existence. Moreover, as trees are important to woodpeckers, so are these birds important to trees. Woodpeckers benefit trees by consuming many of the most destructive forest pests, insects largely inaccessible to other birds. In securing these insects, howerer, which constitute the bulk of their food, and in making nests and shelter cavities, woodpeckers have another significant economic relation to trees, for they remove bark and wood from both dead and living trees. In the case of dead trees little or no harm is done. When, however, they make excavations in living trees, the birds destroy more or less of the cambium layer, from which proceeds the growth of both wood and bark. Slight injuries to the cambium result in distorted growth, but the destruction of large areas may cause death. Since trees are exceedingly valuable to man, the habits of birds whose relations to trees are so vital are of much economic importance.

It is the purpose of this bulletin to examine the evidence for and against woodpeckers and to determine their status according to the effect of their habits upon trees and wood products. Injuries by woodpeckers are treated under two heads: (1) Damage by woodpeckers in general; (2) injuries due almost exclusively to the three species properly known as sapsuckers.

\section{DAMAGE BY WOODPECKERS IN GENERAL.}

This topic may be divided into two sections:-Damage to trees, and damage to wooden.posts and structures.

\section{DAMAGE TO TREES.}

Primarily the work of woodpeckers on the living parts of trees is injurious. The important cambium layer is injured every time a nest is excavated or an insect dug out. To what extent the various 
injuries are offset by beneficial activities of the birds will be discussed later.

\section{HOLES MADE IN DIGGING OUT INSECTS.}

As a rule the holes male by woodpeckers when ligging out insects are not large, and there is every reason to believe that most of them heal quickly without noticeably disfiguring the exterior of the trees. They cause distortion and staining of the wood, however, as do all injuries to the cambium. These lefects of ten resemble those which result from sapsucker work, but they generally occur in otherwise unsound trees and are much less numerous and important. However, wounds made by woodpeckers when digging out borers deeply buried in the wood, by reason of their larger size, often result in bleaching the wood (see Pl. III, fig. 6), a feature rarely observed in connection with the smaller sapsucker pecks.

Our two largest species of woodpeckers, the pileated and the ivory-billed, dig great pits or furrows in living trees or split off large chips. Plate III, figures 1 to 5 , illustrates large wounds made by pileated woodpeckers. F. M. Chapman says: "I have seen an opening made by a pileated woodpecker in a white-pine tree 12 inches long, 4 inches wide, and 8 inches deep, through perfectly sound wood to reach the larræ at work in the heart of the tree." ${ }_{1}$ These large woodpeckers occasionally riddle trees which show no signs of insect attack, but this is so unusual as not to warrant hostility toward these fine birds, which are disappearing only too rapidly as man encroaches upon their domain.

All woodpeckers chip off considerable wood from dead trees and branches to secure the insects therein. In spite of the good done by destroying these insects, in some countries woodpeckers are held in disrepute because they reduce the quantity of firewood, a view not likely to be adopted in the United States.

Indeed, the offices of woodpeckers in capturing the various woodboring insects may be likened to those of the surgeon who removes diseased parts from the human body. Not only do we deem the surgeon's achievement praiseworthy, but we pay him well for doing it. We should maintain the same attitude toward the woodpeckers, surgeons to our trees. Practically all the compensation they demand is the privilege of excavating nests and sleeping shelters in trees.

\section{EXCAVATION OF NEST AND SHELTER CAVITIES.}

There are 24 species (and several subspecies) of woodpeckers in the United States, and although most of them usually select dead stubs or limbs or partly decayed trees in which to make their nests, 
nearly all of them at times choose living trees. Some use living trees almost exclusively and dig a new hole each year; others occupy the same nest year after year. The Williamson sapsucker is one of the species which habitually nest in liring trees. Joseph Grinnell relates that in the San Bernardino Mountains tamarack or lodgepole pines (Pinus murrayana) are selected by that species as nest trees, usually old ones with the core dead and rotten but with a live shell. In one tree he noted a series of 47 holes which penetrated the trunk on all sides up to about 35 feet. Besides these there were many smaller drillings. When once selected by these sapsuckers a tree is doomed, but probably not more than 1 tree in 500 is appropriated by the birds. ${ }^{1}$

\section{ATTACKS OF TREE ENEMIES AIDED BY WOODPECKERS.}

Unlike the surgeons of the human body, woodpeckers neither close the wounds they make nor apply antiseptic treatment, but leave the cuts open to infection. Hence an opportunity is given for a host of enemies, such as bacteria, fungi, and insects, to enter the wound and further injure the tree. While the birds are at fault in so far as they create conditions allowing the inception of damage by these formidable tree enemies, it is evident that blame for all the ensuing injury can not be placed upon them, and it must be admitted that insects, fungi, and bacteria do immense damage with which woodpeckers are in no way connected. It should not be overlooked, however, that old woodpecker holes are of use also to many friends of trees, as they furnish nesting sites for bluebirds, titmice, chickadees, and other insectivorous birds.

\section{COMPENSATION FOR INJURIES DUE TO FOOD AND NEST EXCA- VATIONS.}

After all, however, the question to be decided in regard to the injuries incident to insect hunting and nest excarating by woodpeckers is: Do the services the birds render in destroying the enemies of trees outweigh the damage they inflict? In Bulletin 37 of the Biological Surrey it is shown that most woodpeckers destroy vast numbers of the worst pests of trees, many of which are inaccessible to other birds.

This service by no means exonerates those species properly called sapsuckers, nor does it free from blame woodpeckers which attack structures valuable to man. It does mean, however, that in general we can safely ignore the minor injuries committed by woodpeckers in pursuance of their natural mode of life, and that in practically all cases (with the exceptions noted) woodpeckers living in forests, groves, or orchards do a great deal more good than harm. 


\section{DAMAGE TO WOODEN POSTS AND STRUCTURES.}

However, when woodpeckers depart from their normal activities and inflict injuries in no wise essential to securing sufficient food or proper shelter, we are not bound to pass over the offenses so lightly as those above discussed. Probably the most serious damage resulting from a change of habits is the hollowing out of telephone poles for nest or shelter cavities, so weakening them that they snap off' in high winds.

\section{D.MAGE TO TEIEPHONE AND TELEGRAPH POLES.}

The red-headed woodpecker (Melanerpes erythrocephalus) in some sections commonly chooses telephone poles as nesting sites. The Pennsylvania Telephone Co., of Harrisburg, reports that some years ago many costly poles were destroyed by this species, and Mr. Howard F. Weiss, of the Forest Service, states that 110 out of 268 white cedar poles along a southern railway were bored by this bird. The bird once became a nuisance to the Kansas City (Mo.) Electric Car Co. by drilling the poles carrying the feed cables. A man employed to kill them destroyed 19 in one day. ${ }^{1}$

A related species, the golden-fronted woodpecker (Centurus aurifrons), does similar injury in Texas. Mr. H. P. Attwater says: "Here their favorite nesting sites are in telegraph poles, and there are few that are without woodpecker holes, as they appear to make new ones every year. . . . A line running out of San Antonio to a ranch 9 miles distant was almost destroyed by these birds. They came from all sides, from far and near, and made fresh holes every year, sometimes as many as five or six in a single pole. ${ }^{2}$

Sennett made similar observations on the same bird in the Rio Grande Valley. He says: "The square Government telegraph poles are its favorite nesting place. There is hardly a pole free from their holes, and in one I counted ten; probably some were made by their only relative of that section, Picus scalaris, Texas woodpecker." 3

Farther west a woodpecker, probably the Gila woodpecker ( $C e n$ turus uropygialis), has been a source of trouble and expense to the Southern Pacific Co. for several years, especially along the 200 miles of road between Benson, Ariz., and Guaymas, Mexico. Mr. C. T. Day, assistant superintendent of telegraph on the Sonora division of this railway, says that between Nogales and Guaymas, Sonora, a great many poles have been lost on account of woodpeckers. "We are

I I3ryant, J. A., Osprey, I., 147, Iug., 1897.

2 (2uoted by Bendire, C., Life Histories of N. A. Birds, II, 125, 1895.

3. Sennctt, fien. 13., Notes on the Ornithology of the Lower Rio Grande of Texas. Bull. U. S. Geol. and Geog. Survey Terr., IV, 39, 1878. 
now changing some 300 poles on this account," lie writes. The poles injured "are round cedar, square redwood, and also round creosoted poles; the latter were only placed within the line within the last two or three years. The square poles seem to suffer the most: in many cases we find five or six holes of 3 or 4 inches in diameter in one pole. It seems to be the object of the woodpeckers to dig into the pole for insect life, which the pole may contain, although we find places where they have made nests. The hum of the wires, I think, has something to do with attracting the birds to the poles, which sound they take to be insect life in the pole." (Aug. 17, 1910.)

Besides the species already mentioned, the following are known to injure telephone poles to a greater or less degree: Texan woodpecker (Dryobates s. bairdi), St. Lucas woodpecker (Dryobates s. lucasanus),- California woodpecker (Melanerpes $f$. bairdi), red-bellied woodpecker (Centurus carolinus), yellow-shafted flicker (Colaptes auratus), and red-shafted flicker (Colaptes $c$. collaris). The California woodpecker, besides making nest cavities, perforates the entire surface of poles with small holes in which to store nuts. (See PI. IV, fig. 1.) Howerer, "decay is the great cause of destruction of poles. It is estimated that approximately 95 per cent are destroyed by this cause and only 5 per cent by breakage or mechanical abrasion." 1 How much of the breakage is due to the weakening of posts by woodpeckers is unknown, but the damage is nowhere near as great as commonly supposed. Mr. Howard F. Weiss, of the Forest Service, discusses the effects of woodpecker attack on poles, in the Engineering News of February 23, 1911 (vol. 65, No. 8, p. 220), from which we quote at length:

The number of holes in each pole may vary from one to a dozen or more, although these larger numbers are not common. The size of the hole varies from about $\frac{1}{2}$ to 3 inches diameter. When used for nesting sites the birds may hollow out a pocket 6 to 10 inches in diameter and a foot or more in depth.

The question of interest to telephone engineers is to just what extent such poles are weakened. The following example may be of interest. It has been found from measurements on two hundred and fifty 30 -foot northern white-cedar poles that their average taper is approximately as follows:

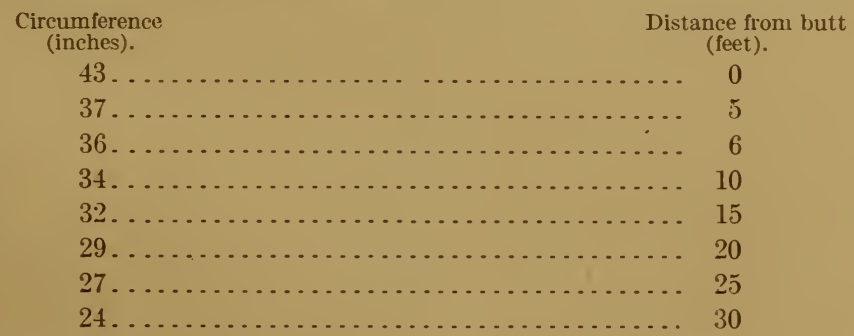

1 Bureau of Census, Forest Products, No. 10, p. 106, 1909. 
Assuming the pole as a cantilever, loaded at one end, it is found that it may be hollowed to the extent shown in the figure without decreasing its strength. The length of ordinate between shaded area and right-hand edge of the diagram represents the thickness of outer shell which must he sound. For example, at 10 feet from the ground if only 2 inches of the outer shell are left, the pole will be approximately as strong as though it were solid. This grants the bird permission to build a house

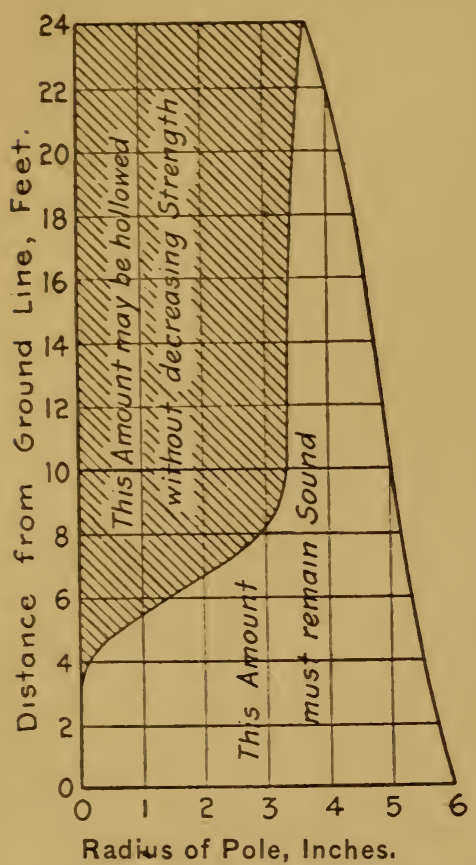

Diagram showing the extent to which a pole can be hollowed by birds, without appreciably decreasing its strength. about 6 inches in diameter. The higher up the pole it goes the larger can be its nest without injury. If, however, the attack is less than 4 feet from the ground the pole will be appreciably weakened.

This illustration neglects the damage done by the entrance into the pole, or the subsequent decay which may follow, and assunies that the bird builds its nest exactly in the center-a condition not always found in fact. On the other hand, it assumes that the pole has a uniform moisture per cent throughout its length and that the outer fibers at the ground line are perfectly sound. These conditions seldom, if ever, exist in practice, as the pole, particularly if it has been set for a year or more, always contains more moisture near the ground than at any point above it, and the sapwood at the ground is invariably more or less decayed. Hence, the birds could peck even larger holes than those shown in the sketch without increasing their danıage.

The engineering department of the American Telephone \& Telegraph Co. made a few tests in 1908 near Zanesville, Ohio, to determine the effect of woodpecker attacks upon the strength of poles. These tests were made by fastening a rope around the top of the pole and pulling with a block and tackle to which a dynamometer was attached. In 9 cases out of 12 the poles broke at the ground line and not at the points attacked by the birds. The examples in the accompanying table are typical.

Typical results of tests of damaged poles; American Telephone \& Telegraph Co., Zanesville, Ohio.

\begin{tabular}{|c|c|c|c|}
\hline & Pole No. 6390. & Pole No. 6325. & Pole No. 6372. \\
\hline 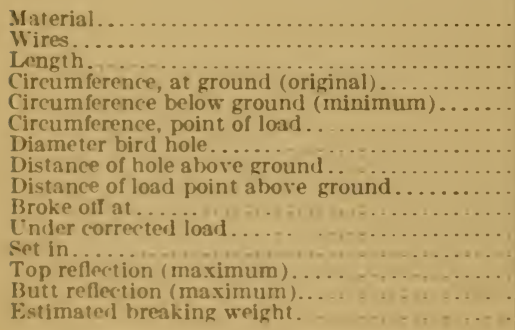 & 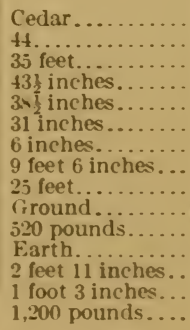 & 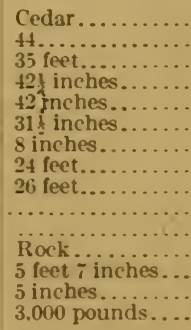 & $\begin{array}{l}\text { Cedar. } \\
44 . \\
35 \text { feet. } \\
401 \text { inches. } \\
35 \text { inches. } \\
27 \text { inches. } \\
\text { (See note.) } \\
\text { Ground. } \\
1.100 \text { pounds. } \\
\text { Earth. } \\
2,000 \text { pounds. }\end{array}$ \\
\hline
\end{tabular}


After pole No. 6390 broke as above shown it was reset and tested as a 30 -ioot pole, and it broke at the new ground line ( $40 \frac{1}{2}$ inches circumference) under 1,000 pounds corrected load. It had a $2 \frac{1}{2}$-inch shell at break. Estimated breaking weight as a 30-foot pole, 2.500 pounds.

Pole No. 632.5 was sound at the ground and set in wet rork hole, with about 10 inches of clay on top. At 3.000 pounds, actual reading, the dynamometer slipped. The load was applied for 300 pounds more, when the rope broke and test was abandoned.

Pole No. 6:3:-2, at 1.100 pounds. corrected load, gave way at ground. but did not quite break off. There were 10 woodpecker holes between 15 and 20 feet above ground, as follows:

13 ieet above ground.................. 3 by 3 inches, 4 inches deep.

17 feet above ground.................. 3 by 3 inches, 5 inches deep.

18 ieet above ground................. 3 by 3 inches. 3 inches deep.

19 feet above ground.................. 3 by 3 inches. 5 inches deep.

At fith gain, 30 -inch circumierence. 6 smaller holes.

It appears, thereiore, that the attack of poles by these birds is not as serious as one would be prone to believe, and. taking into account the great good that they do in eating insects, the destruction of our ieathered iriends can by no means be justified by the injury they do to pole-line construction.

\section{DAMAGE TO FEXCES AND BLILDINGS.}

The downy, hairy, Texas, California, and red-headed woodpeckers and both the rellow-shafted and the red-shafted flicker are known to excarate holes in fence and gate posts, but the loss is much less than in case of telephone poles. Indeed, it is probable that in most cases where woodpeckers nest in fence posts about yards and farms the owner is glad to hare them there because of the number of insects ther destror. To sar the least, it would be an adrantage to hare them nest in fence posts rather than orchard trees. for instance, and they would still risit the trees to glean insects.

As woodpeckers excavate poles and fence posts, it is not surprising that they attack other wooden structures. The usual trpe of injury of this class is drilling holes into cornices or under eaves of houses or piercing the walls of barns and sheds.

Buildings that are unoccupied most of the time, as schoolhouses and churches, are frequently defaced, church towers or steeples being farorite points of attack. The red-headed woodpecker is an old offender in this respect, and a case is recorded ${ }^{1}$ where in one season 22 of these birds were killed one after another while attempting to make a nest in a church steeple. During the caretaker's absence a pair finally completed a nest and reared their young. The red-bellied woodpecker also sometimes makes holes in houses. but the flickersthe yellow-shafted in the East and the red-shafted in the West-are the woodpeckers that show the strongest predilection for boring into buildings. Often many holes are made in the same wall. (Pl.Y,fig. 1.) Apparently the birds learn little by experience, but keep on drilling 
openings into large cavities unsuited for either nests or shelter. When occupied houses are attacked, the loud calls and racket made by the birds, especially in the early morning, are very annoying to the immates.

The ('alifornia woodpecker (Melanerpes $f$. bairdi), besides making holes in houses for nests or sleeping quarters, also pecks in cornices a multitule of small holes, wherein acorns are wedged. The bird usually stores the mast in dead limbs of trees, but when acorns abound near buildings it naturally takes advantage of the large exposed surface of dead wood as exactly suited to its purposes. This hoarding instinct undoubtedly has for its basis the provision of food for future use, but the woodpeckers store up immense quantities of acorns which they never eat, most of which fall to the lot of the squirrels and jays.

H. W. Henshaw found the California woodpecker making much use of buildings for storage purposes near Ukiah, Mendocino County, Cal. He was informed that one schoolhouse (Pl. IV, fig. 2) was so much injured in a season or two that it was replaced by a new building in preference to making the necessary repairs.

\section{PREVENTION OF DAMAGE BY WOODPECKERS.}

The prevention of damage by woodpeckers (except sapsuckers) rarely necessitates destruction of the birds. Moreover, woolpeckers are so valuable as conservators of trees that the public should not be deprived of their services.

It has been claimed that creosote insures telegraph poles against the attacks of woodpeckers, but Mr. Weiss presents evidence to the contrary in the paper previously quoted from (pp. 11-13), and Mr. ('. T. Day says concerning results in Sonora:

Some of the creosoted poles about 9 or 10 inches in diameter have been picked, leaving an outside shell. In two or three instances the linesmen have found the inside of poles entirely eaten away . . . and found birds' nests inside. It is a common expression with the linesmen that the woodpeckers get fat on creosote. We tried spraying with earbolic acid in places where their holes were just begun, but so far we have been unable to notice any difference. We are now substituting a Texas pine polk, burnetized, with a creosoted butt, which is claimed to be so much harder than creosote that birds will have considerable difliculty in getting into it. We have some 200 poles up, but as yet they do not show any marks.

The results of experiments of this kind will he awaited with interest. It will be fortunate, indeed, if some one or other of the preservative treatments which are applied to nearly all poles now being set is found to protect them from woodpeckers. As telegraph poles are usually perforated by woodpeckers for the purpose of securing nesting sites, the providing of nest boxes may prove a comparatively cheap and easy solution of the difficulty. If nest boxes be supplied and 
utilized by the birds, the poles should be reasonably exempt from attack. Those suitable for woodpeckers (similar to that illustrated by figs. 1 and 2) cost 25 cents each in lots of 20 or more. They may be used to protect trees, fence posts, and buildings, as well as telegraph and telephone poles.

Among native species flickers and the golden-fronted and redheaded woodpeckers have been known to use nest boxes, but few trials of them have been made in the United States. However, such

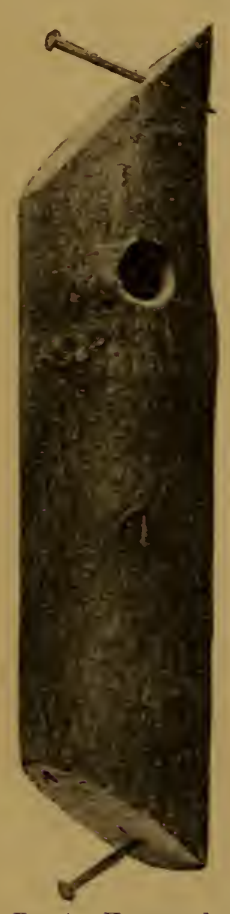

Fig. 1.-Homemade nest box for woodpeckers.

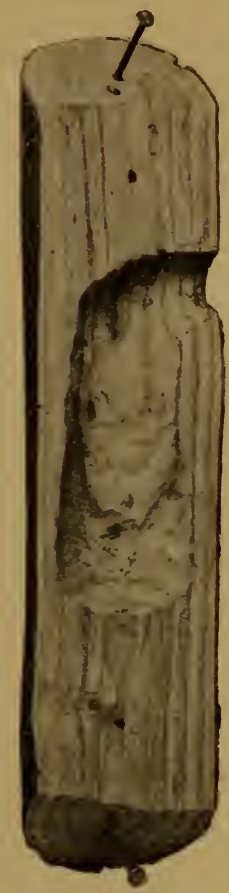

FIG. 2.-Longitudinal section of nest box shown in figure 1 .

experiments have proved very successful in Europe, as the following account of their utility in Germany, where they have been employed extensively, shows:

Wherever these nesting boxes have been hung up, great success has been the result. All the breeders in holes ... have inhabited them. ... Ninety per cent of the 2,000 boxes in the wood at Kammerforst . . . and nearly all of the Seebach and of the 2,100 near Cassel were occupied. . . . The Prussian board of agriculture has caused extensive experiments to be made with these boxes, with excellent results. Of the 9,300 boxes hung up by the Government in the State and communal woods of the Grand Duchy of Hesse, 70 to 80 per cent were used the first year, and all have been inhabited this year (1907). ${ }^{1}$ 
It is sometimes practicable to prevent damage by woodpeckers by covering objects with tin. This does not apply to buildings, of course, and when injury continues despite nest boxes and other protective devices more strenuous action is permissible. Do not try to kill the offenders by putting out poisoned food or water, for you will kill more friends than enemies. Some States properly permit the shooting of birds by the owners of premises that are manifestly being damaged. Shooting should be allowed only when actual damage is being done and then only under supervision of a proper authority.

\section{DAMAGE BY SAPSUCKERS.}

\section{DISTRIBUTION AND HABITS OF SAPSUCKERS.}

Many woodpeckers are commonly termed sapsuckers, but there are only three species properly so called: The yellow-bellied sapsucker (Sphyrapicus varius) (PI. I), the red-breasted sapsucker (Sphyrapicus ruber) (PI. I), and the Williamson sapsucker (Sphyrapicus thyroideus) (PI. II). The yellow-bellied sapsucker (known also as red-throated sapsucker, squealing woodpecker, and whining woodpecker) together with its western form, the red-naped sapsucker (Sphyrapicus varius nuchalis), ranges over practically the whole of North America up to $60^{\circ}$ north latitude, breeding from the northern limits of the range south to Massachusetts, Indiana, Colorado, and throughout the Rocky Mountain region, and migrating over the remainder of the continent as far as the West Indies and Central America. It sometimes winters as far north as the southern boundary of the breeding area. The red-breasted sapsucker, locally called the red-headed woodpecker, nests from northern Lower California through the Sierra and Cascade Mountain Ranges to southern Alaska, withdrawing in winter to that part of its range south of middle Califormia. The Williamson sapsucker, the male of which was long known as the black-breasted and the female as the brown-headed woodpecker, occupies in summer the higher parts of the country from the eastern slopes of the Rocky Mountains to the Pacific coast, from Arizona and New Mexico to southern British Columbia, and winters from Texas and southern California south through the greater part of Mexico.

The sapsuckers are a distinctly marked group of woodpeckers and are held by some authorities to constitute a separate subfamily. Most woodpeckers have long tongues which can be thrust far out of the beak and which are armed at the tip) with backward projecting spines (fig. 3), enabling the birds to secure their insect prey although deeply buried in wood. The sapsuckers, on the contrary, have short, practically nonextensible tongues, furnished with a fringe of stiff hairs (fig. 4), not adapted to the capture of wood-boring insects. 


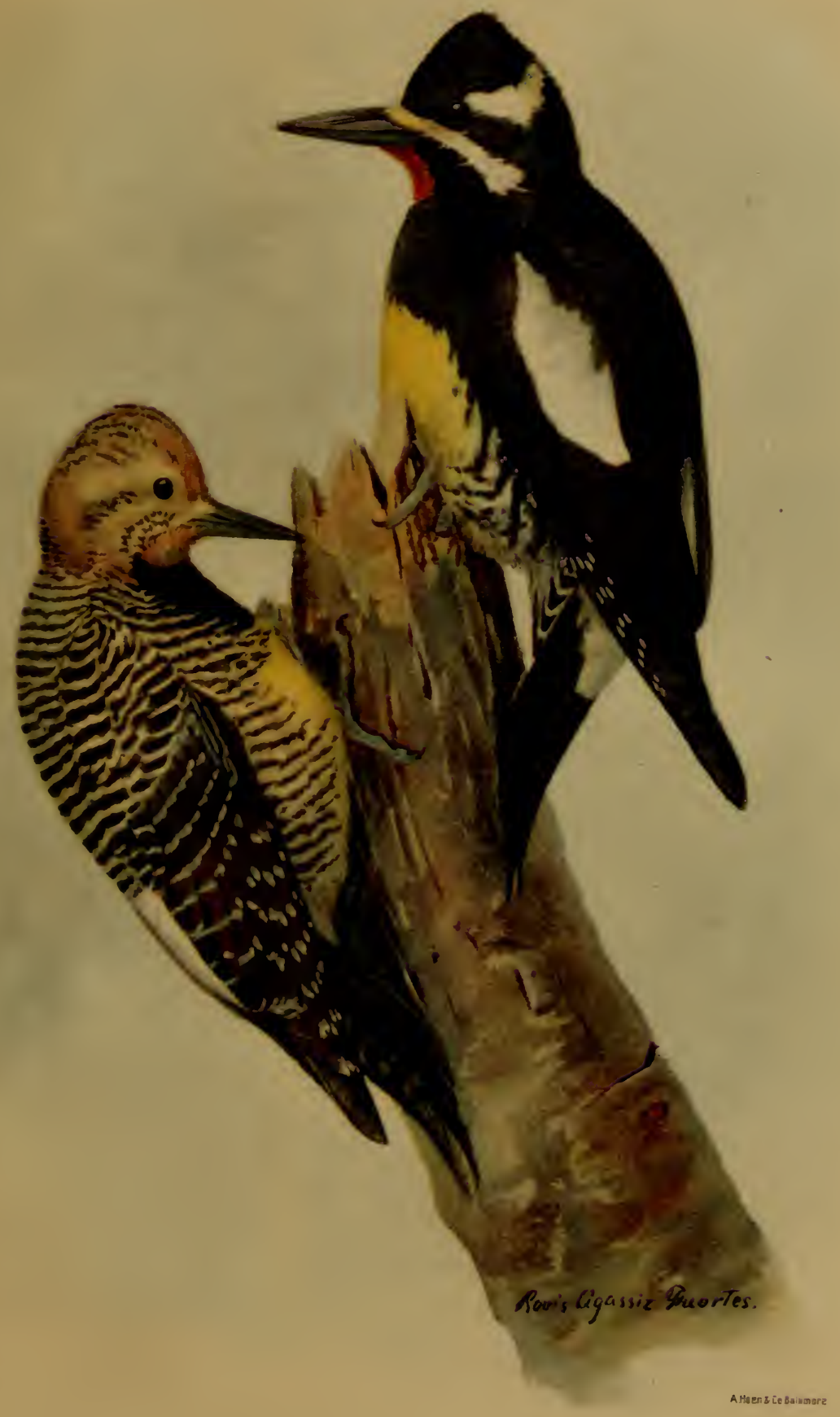

WILLIAMSON SAPSUCKER.

[Left figure, female; right, male.] 



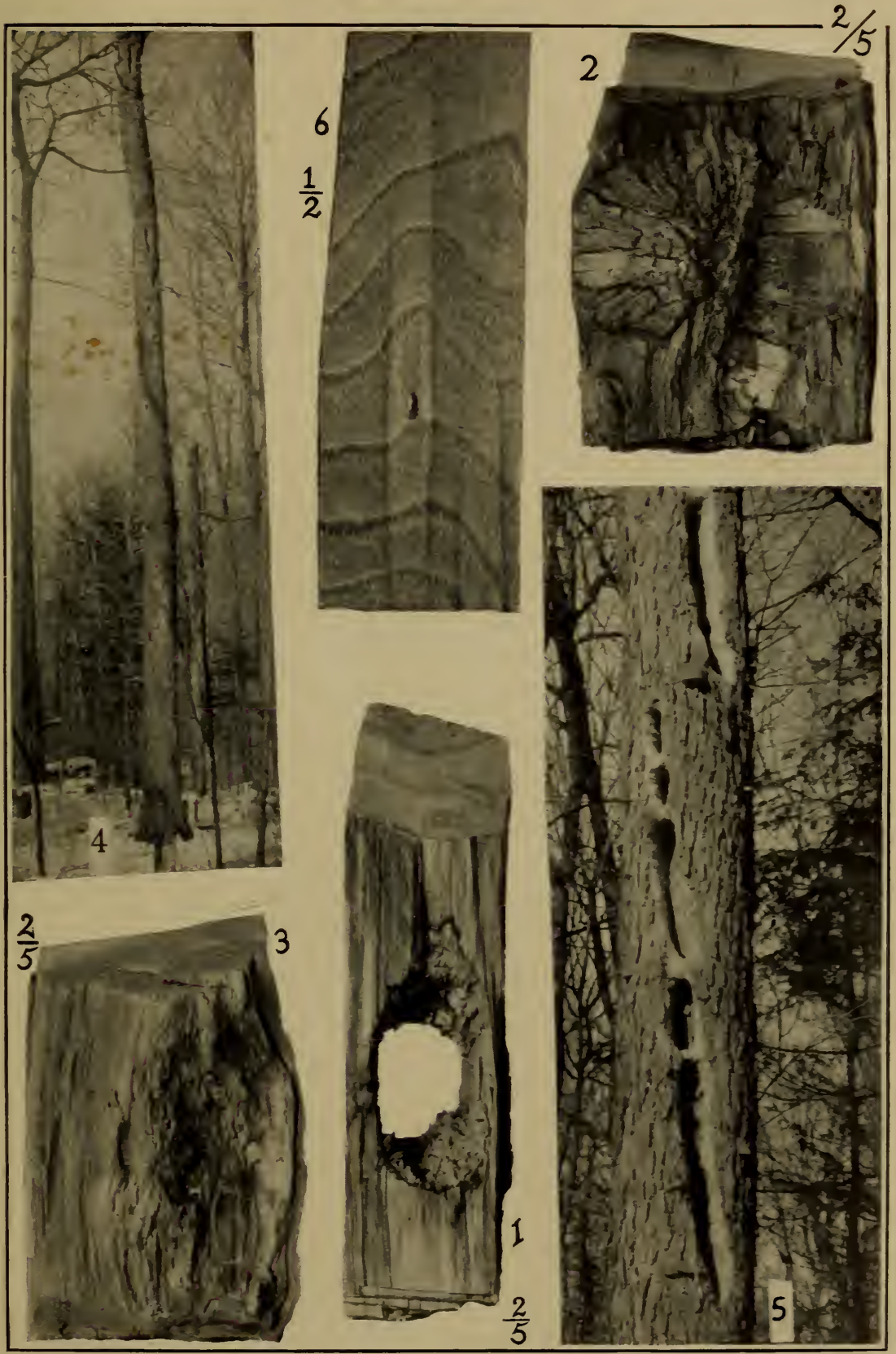

WORK of PILEATEd WOOdPECKer; Bleached WaLnUt WOOd.

[1. Hole made in canoe cedar (Thuja plicata) br pileated woodpecker in search of insects. 2, Healed excavation in same wood, outside riew. 3, same, inside view. 4 and 5 , Excarations br pileated wondpecker in dead deciduous trees, Vilas Countr, Wis. By H. S. Barber. 6, Bleached streak in black walnut, caused by woodpecker's food excaration.] 

Plate IV.

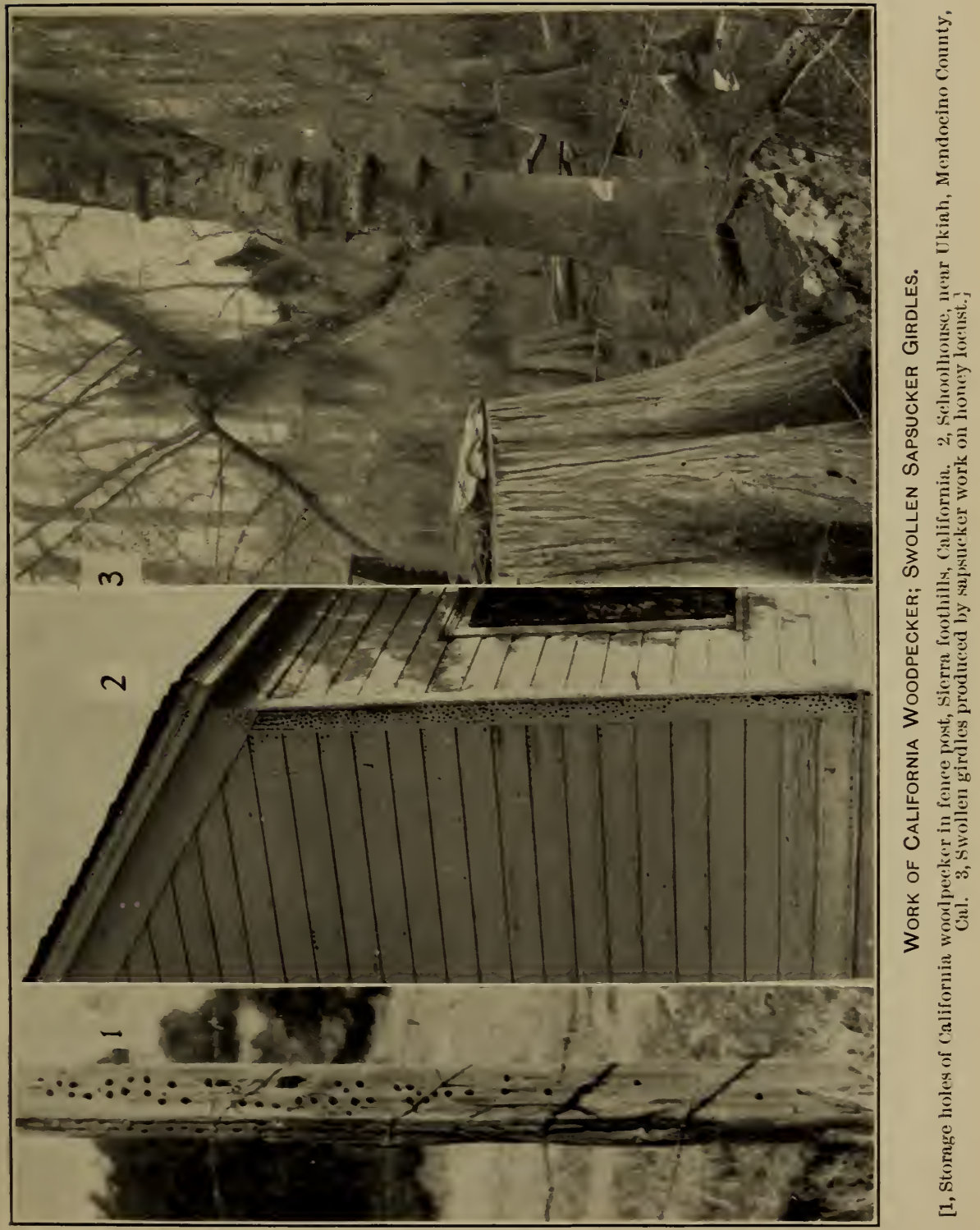





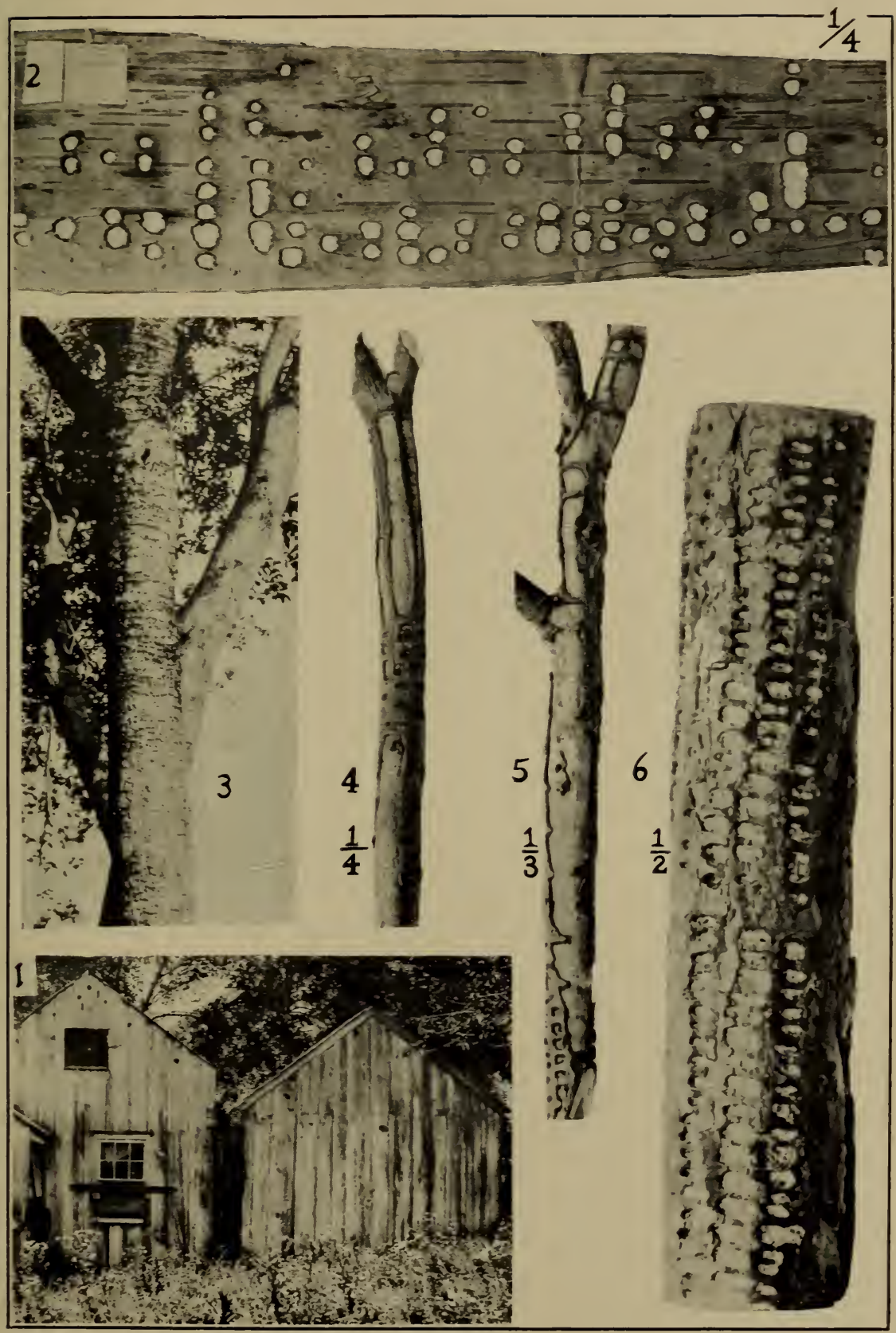

WORK OF FLICKER AND SAPSUCKERS.

[1, Holes made by flicker in ranch buildings near Haywards, Cal. 2, Type of sapsucker work on white birch: 3, on apple; 4 , on willow (salix cordata), holes enlarged rertically by continued excaration at upper end; 5 , on willow, almost complete barking; 6 , on pitch pine, tree killed.] 

In keeping with their peculiarities of structure, these brushtongued woodpeckers have peculiar food habits. They are the true sapsucking and cambium-eating species. They girdle and kill many trees, either by destroying extensive areas of the cambium or more commonly by removing many small pieces in such a way as to sever most if not all the channels carrying the elaborated sap from which both wood and bark are formed.

The three species are probably equally to blame. While it has been asserted that the red-breasted and Williamson sapsuckers harm trees less than the yellow-bellied, these statements are probably founded on insufficient information. There is a dearth of data respecting the habits of

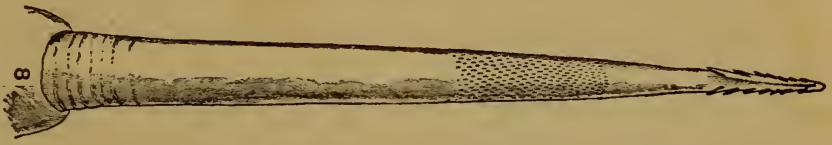

FIG. 3.-Spiny tongue of downy woodpecker (Dryobates pubescens). (From Lucas, Rept. U. S. Nat. Mus., 1895.)

these two woodpeckers, but similarity of structure and the evidence of stomach examinations indicate that the three species of sapsuckers are much alike in their cambium-eating habits and hence all three are injurious to trees. The Williamson sapsucker, however, is strictly an inhabitant of pine forests and aspen groves at considerable elevations, and therefore under present conditions is not likely to injure trees of great value to man.

Stomach examinations show that the red-breasted sapsucker consumes enough cambium and bast to average 12.16 per cent of its food. The same food constitutes 12.55 per cent of the stomach con-

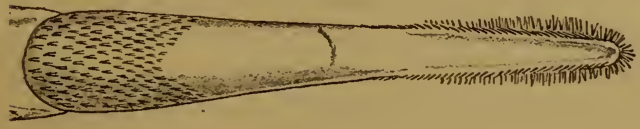

FIG. 4.-Brushy tongue of sapsucker (Sphyrapicus varius). (From Lucas, Rept. U. S. Nat. Mus., 1895. tents of the Williamson sapsuckers examined and 16.71 per cent of the yellow-bellied woodpecker's diet, an average amount for the three of 13.8 per cent. It must be noted also that cambium is a very delicate, perishable material, at certain times no more than a jelly, and thus never receives a percentage valuation in examinations of long-preserved stomachs corresponding to its bulk when first swallowed. Neither do we get any record of the sap consumed by these birds, and they are inordinate tipplers. ${ }^{1}$ Hence the value of the percentages cited lies not so much in their accuracy as to the quantity of cambium eaten as in the fact that they indicate a steady consumption of this important substance. There

1 A yellow-bellied sapsucker has been observed to remain within a yard of some of its holes in a maple tree, drinking the sap at frequent intervals, from $10 \mathrm{a}$. m. to $5 \mathrm{p} . \mathrm{m}$.

99068 - Bull. 39-11-2 
is no doubt that cambium, bast, and sap are depended upon by sapsuckers as staple diet.

The results of sapsucker attacks on trees are so uniform and characteristic as to be distinguished easily from the work of other woodpeckers. Sapsucker holes are drilled clear through the bark and cambium and often into the wood. They vary in outline from circular to squarish elliptical, in the latter case usually having the longer diameter across the limb or trunk. Generally they are arranged in rings or partial rings around the trunk, but they of ten fall into rertical series. Deeply-cut holes arranged with such regularity are made only by sapsuckers.

After the original pattern of holes is completed, the sapsuckers often continue their work, taking out the bark between holes until sometimes large areas are cleanly removed. This often occurs on small limbs or trunks, where long strips of bark up and down the tree are removed, leaving narrow strings between. This effect is also produced by continually enlarging single punctures by excavating at the upper end (Pl. V, fig. 4), which is done to secure fresh inner bark and a constant supply of sap. Occasionally, after a tree has been checkered or grooved after the above-described systematic methods, it may be barked indiscriminately, leaving only ragged patches of bark. (Pl. V, fig. 5.) Even in such cases, however, traces of the regularly arranged punctures are likely to remain, and there is no difficulty in recognizing the work as that of sapsuckers, for no other woodpecker makes anything like it on sound, living trees.

All holes, grooves, or irregular openings made by sapsuckers penetrate at least to the outermost layer of sapwood or nongrowing part of the tree. This results in the removal of the exterior rough bark, the delicate inner bark or bast, and the cambium. Since the elaborated sap (upon which the growth of trees depends) is conveyed and stored in these layers, it is evident that sapsuckers attack the trees in a vital part. Each ring of punctures severs at its particular level part of the sap-carrying vessels, another ring made above destroys others, and so the process continues until in extreme cases circulation of elaborated sap stops and the tree dies. When the injury to the vital tissues is not carried so far, only a limb here and there may die, or the tree may only have its vitality lowered for a few years. If the attacks cease, it may completely recover.

\section{EFFECTS OF SAPSUCKER WORK ON THE EXTERNAL APPEAR- ANCE OF TREES.}

Recovery, however, does not mean that the tree has escaped permanent injury. Patches of cambium of varying size may be killed. Growth ceases at these points and the dead and discolored areas are 
finally covered by wood and bark. Until this process is completed, the tree is disfigured by pits with dead bark and wood at the bottom, and eren when completely healed, the spot remains a source of weakness. In fact, all sapsucker pecking is followed by more or less rotting and consequent weakening of the wood, and renders trees more liable to be broken by the wind or other causes.

Sapsucker injuries usually stimulate growth of the wood layers at the points attacked, so that they become much thicker than usual. This results in a slight swelling of the bark, and when the birds reopen the old wounds year after year, as they habitually do, succeeding wood layers make excess growth and in time shelflike girdles develop. On trees having thin, flexible, rapidly growing bark, the swollen girdles are smoothly corered and rounded (fig. 5; Pl. IV, fig. 3 ), but on trees having thick, brittle, or stiff bark, the bark breaks and a gaping furrow is formed at the summit of the swelling (Pl. VII, figs. 2 and 3 ; Pl. VIII, fig. 1; Pl. IX, fig. 2; Pl. X, fig. 1). Some trees are remarkably deformed by such protruding girdles (fig. 5.)

Buds are apt to start from the edges of holes drilled by sapsuckers and form twigs or small branches. Such shoots hare been noted on honey locusts and sycamores, and in some trees, such as willows and elms, which are prone to produce adrentitious buds, they arise from sapsucker injuries in such numbers as to materially disfigure the trees.

The bark may be otherwise disfigured, as by exudations of gum or by pitch streams, or sapsucker injury may be followed by fungus attack, as in certain

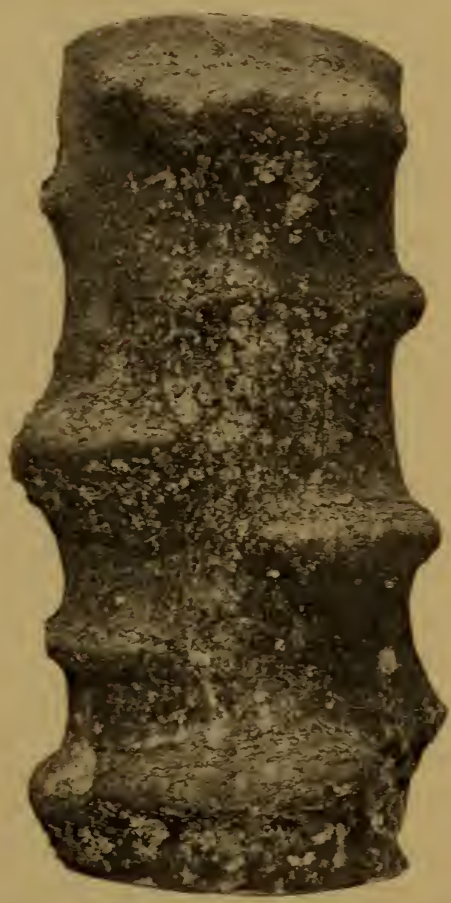

FIG. 5.-Sapsucker work on honey locust (Gleditsia triacanthos). Protruding girdles. Specimen is 18 inches in diameter. pines. Spores of Peridermium cerebrum sometimes reach the wood through sapsucker punctures and cause knotty gall-like outgrowths which greatly disfigure the trees.

The wood also is often distorted and discolored in such a way as to destroy its commercial value. This phase of damage by sapsuckers is exceedingly important and will be made the subject of a separate section of the bulletin. 


\section{EFFECTS OF SAPSUCKER WORK ON THE HEALTH OF TREES.}

\section{Bendire says: "In certain localities, as where apple orchards are} abundant, it [the yellow-bellied sapsucker] becomes a nuisance, and materially injures and eventually kills many such trees." 1 In the State of Washington whole orchards of young apple trees have been destroyed by sapsuckers, either by the western form of the yellowbellied woodpecker or by the red-breasted sapsucker. The latter species injures other trees also, as related by Ellwooc' Cooper, of Santa Barbara, Cal. He says:

There were no trees killed outright at the time the sapsuckers were so bad, but many of them ceased to be useful as fruit bearers. Some apple trees died back at the top and did not thrive, so that I cut them down as useless, also a few English walnut trees. The orange trees had iny special attention. I used the knife, cutting out the injured place, covered the wood with grafting wax, and liad the bark heal over. The trees are living now and thriving. I have a few blue gums (Eucalyptus globulus) that show injury at this time. I consider the birds a pest. There were many other trees injured. I hired a boy to shoot the red-headed woodpeckers [i. e., the red-breasted sapsuckers] and intend to do so the coming spring. (Jan. 22 and Feb. 8, 1909.)

B. Horsford, of Springfield, Mass., writes as follows concerning the yellow-bellied sapsucker:

I have seen the white birch cut off, or rather broken off, 20 feet from the ground in more cases than I can number - all his work. I have seen the yellow birch destroyed in the same manner-branches of the tree cut off, shriveled branches struggling for life, but dying. I have seen a tree girdled with spots 20 feet from the ground, then again a few feet lower, then below that, repeating the process to the roots, leaving a dead and dry section above each belt. I have seen the white pine destroyed in the same way. . . . I have seen an elm tree 18 inches in diameter, whose trunk of 12 feet was spotted with "gimlet holes" . . . where for 10 summers past I have shot the pest and thereby saved the tree. . . . Where the bird breeds, whole orchards are severely injured, if not destroyed. . . . The leaves fade and the fruit withers on the stem or falls to the ground. Perhaps not half the apple trees attacked are killed outright, but the birch tree invariably dies. ${ }^{2}$

Even forest trees are not immune from injury by sapsuckers. Prof. W. W. Cooke, of the Biological Survey, states that near Lake Itasca, in northern Minnesota, where the birds breed, the yellowbellied is the most common woodpecker. It does much mischief among forest trees, killing many great poplars by its girdles.

Mr. A. W. Butler says:

It knows when sugar making begins. . . . I have found their borings, from which sap was flowing, February 19, 1896. Through March and $A$ pril they continue their work. . . . In fall when they come to us they resume their work of piercing the bark of maple, apple, and other trees. . . . I have found their fresh work on young apple trees, never before pierced, as late as November 19, 1595. Pine trees are also girdled, chiefly, however, through the winter, for among them the sapsucker spends his winter, and about lawns where pines and maples grow together they are most commonly found at that season. By spring they have removed most of the bark scales 
from the pine, and it then appears quite clean. The resin flows from the wounds the bird has made and forms milky streaks and gummy excrescences later in the season, which look unsightly. . . . The pines are weakened, their tops girdled until they become bent and even blown off by the wind. Apple trees and choice maples are seriously damaged. . . . I have counted six of these birds at one time on a dozen sugar maples in front of one lot in my own town, and have seen the sap flow in a stream. ${ }^{1}$

Dr. P. R. Hoy gives evidence of damage by yellow-bellied sapsuckers. In 1865 he wrote as follows:

They . . . energetically attack the maple, mountain ash, pine, spruce, pear, apple, plum, cherry, peach, and silver poplar, . . . ironwood, wild cherry, and basswood. ... It is during the autumnal visit that they do the greatest damage; for in spring, when the vital forces of vegetation are unusually active, the tree recovers more certainly from the wounds inflicted, while in the fall, vegetable life being less active, the septa between the punctures are more likely to dry, leaving the tree dead or crippled for life. The sapsuckers attack the most thrifty trees, but after they have suffered a siege from these sapsuckers, they are thrifty no more. If not killed, they are so stunted that they fall an easy prey to the bark lice, . . . for when an orchard tree is enfeebled from any cause, bark lice are sure to finish the work. . . . The damage done by these birds to orchards and ornamental grounds is considerable, second only to that of the bark louse. There is not a garden or orchard of anysize in the vicinity of Racine [Wis.] that has not lost trees killed by the sapsucker. ${ }^{2}$

The instances above cited are sufficient to show that sapsuckers materially injure or even kill many trees of a wide variety of species. Subjoined are lists of the trees attacked by the three species of sapsuckers as complete as present information permits.

\section{TREES ATTACKED BY THE YELLOW-BELLIED SAPSUCKER.}

(Sphyrapicus varius.)

In these lists field notes on damage to certain trees are given, with locality and name of observer. The writer is responsible for citations with localities only (most of which are vouched for by specimens in the Biological Surrey), for unsigned field notes, and for records of specimens in museums. The following abbreviations are used: A. A., Arnold Arboretum; A. M., American Museum of Natural History; F., Field Museum of Natural History; H., Hopkins collection. These symbols are accompanied by the numbers of the specimens in these wood collections. Notes from published sources are followed by the name of the author, and the bibliography following the lists supplies the complete references. The exception is a paper read by Dr. A. D. Hopkins before the Biological Society of Washington, which, although unpublished, is inserted in the bibliography. We are under the greatest obligations to Dr. Hopkins, who has furnished a vast amount of valuable data on sapsucker work. The scientific names of the trees agree in the main with those of Britton's North American Trees. ${ }^{3}$ 
Names of families and the statisties as to the number of species in them are from the same book.

Included in this list are the names of many trees attacked by sapsuckers, but by which of the three species is not known. In view of the immense range of the yellow-bellied sapsucker, probably all these trees are at some time or other punctured by this species. Many of them are undoubtedly attacked by one of the other species, especially in the West by the red-breasted sapsucker.

The information concerning sapsucker attack on trees of various families is summarized for each family before presenting the evidence relating to the individual species. Following the family summaries are lists of all the species attacked, with detailed accounts of the species notably injured.

The yellow-bellied sapsucker, in addition to attacking trees, also works upon several vines. Sometimes a vine is riddled while the tree which supports it is untouched. The vines upon which punctures have been noted are:

Dutchman's pipe (Aristolochia macrophylla).-West Virginia (F.), Abbeville, La.

Poison IVY (Rhus toxicodendron).-This vine is abundantly punctured by sapsuckers and sometimes partly or entirely killed, as at Longbridge, La.

Rattan vine (Berchemia volubilis).-Abbeville, La.

Frost Grape (Vitis vulpina).-Longbridge and Abbeville, La.

Virginia creeper (Psedera quinquefotia).-Plummers Island, Md.

Trumpet creeper (Tecoma radicans).-Cottonport and Abbeville, La.

These 6 species of vines belong to 5 families, 2 of which are not otherwise represented in the list.

\section{THE MAIDENHAIR TREES (GINKGOACEA).}

This family contains only a single species, a native of Japan, which is commonly cultivated for ornament in the United States. It is vigorously attacked by sapsuckers, but so far as known it is not materially defaced.

Maidenhair tree (Ginkgo biloba).-Along the central avenue of the Agricultural Department grounds in Washington are 76 trees of this species, of which 29, or 38 per cent, have been pecked by the yellow-bellied sapsucker. Some of the trees show numerous punctures, and in a fow cases swollen girdles have resulted. One tree which divides into ten main trunks is closely punctured all over. The trees are disfigured, but as they are not especially prized for beauty of trunk, the blemishes are not serious. 
THE YEW FAMULY (TAXACEE).

Four arborescent species of this family occur in the United States, and three of them are known to be attacked by sapsuckers. These trees are little used for ornament, and as yet we have no evidence that sapsucker attacks have weakened or killed any of them.

LIST OF TAXACE E ATTACKED.

Florida Yew (Taxus floridana),-Bristol, Fla. (A. A. and A. M. 411).

Stinking CEdaR (Tumion taxifolium),-River Junction, Fla. (A. A. and A. M. 414.)

California NutMeg (Tumion californicum),-California (A. A. and A. M. 413).

THE CONE-BEARING TREES (PINACEE).

This large and important family of trees includes many of the finest ornamental forms. Almost half of the total number of native species, as well as several introduced forms, are known to be attacked by sapsuckers. The following table shows the number of indigenous species in each genus of the family and the number subject to attack by sapsuckers. There is little doubt that all are punctured at times.

Pinaceæ attacked by sapsuckers.

\begin{tabular}{|c|c|c|c|}
\hline Genus. & $\begin{array}{l}\text { Number } \\
\text { of native } \\
\text { species. }\end{array}$ & $\begin{array}{l}\text { Number } \\
\text { of these } \\
\text { attacked. }\end{array}$ & $\begin{array}{l}\text { Introduced } \\
\text { species } \\
\text { attacked. }\end{array}$ \\
\hline \multirow[t]{2}{*}{ 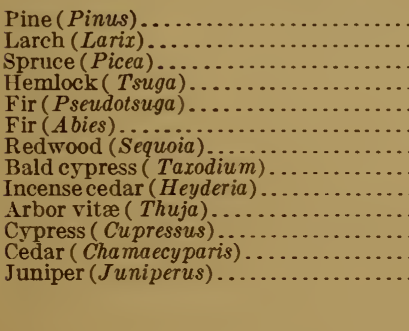 } & $\begin{array}{r}36 \\
3 \\
8 \\
4 \\
2 \\
10 \\
2 \\
2 \\
1 \\
2 \\
5 \\
3 \\
12\end{array}$ & $\begin{array}{r}16 \\
0 \\
3 \\
3 \\
1 \\
5 \\
2 \\
1 \\
1 \\
1 \\
3 \\
1 \\
5\end{array}$ & $\begin{array}{l}2 \\
1 \\
1 \\
0 \\
0 \\
0 \\
0 \\
0 \\
0 \\
0 \\
0 \\
0 \\
0\end{array}$ \\
\hline & 90 & 42 & \\
\hline
\end{tabular}

Several of the species attacked are known to have been seriously injured or killed, including 6 native and 2 introduced pines, 2 native and 1 introduced spruce, 2 native hemlocks, 2 firs, and 1 juniper.

For Butler's testimony concerning injuries to pines see pages 20-21. Steere makes a more serious charge, saying the bird "injures and oftentimes kills the pines, making so many holes that the trees bleed to death" (Annapolis, Md., Aug. 24, 1885). 
Spruces, if not killed, are weakened and rendered unsightly. Wright says:

Here, in the garden, they attacked a large spruce one autumn, and the next spring the trunk was white with the sap that leaked from the hundreds of "taps," and the tree has never since recovered its vitality.

Among the coniferous trees so badly affected are the most beautiful and valuable ornamental species, defacement or destruction of which is a serious oflense.

LIST OF PINACEA ATTACKED.

White pine (Pinus strobus).-Whe white pine is the most important tree of the eastern United States and is a valuable ornamental species. Hopkins states that young trees are injured or killed by sapsuckers; Horsford notes that he has "seen the white pine destroyed" by these birds; and Warren says: "In one garden [in Racine, Wis.] all the . . . white pine trees were entirely killed." Evidently this species suffers severely from sapsuckers, and, as it is so valuable, the loss is serious.

Llimber pine (Pinus flexitis).-Colorado (A. M. 499).

Whitebark pine (Pinus albicaulis).-Washington (A. M. 498).

One-Leaved nut PINe (Pinus monophylla).-California (A. A. and A. M. 492).

Nut Pine (Pinus edulis).-Vermejo, N. Mex., May 6, 1903, (H.).

Chindanua Pine (Pinus chihuahuana).--Southern Arizona (A. M. 491).

RED PINE (Pinus resinosa).--This species is rather infrequently used for ornamental purposes and generally goes under the name Norway pine. Butler (1890) says: "Norway pines in my yard have been girdled until they became puny, sickly trees and were cut down, and one tree was so girdled about two-thirds of its height from the ground that it was broken off during a windstorm." A red pine in the grounds of the Smithsonian Institution at Washington bears considerable sapsucker work.

Bull pine (Pinus ponderosa mayriana).- Santa Rita Mountains, Ari\%. (A. M. 489).

Lodgepole PINe (Pinus murrayana).-Uintah Mountains, Medicine Bow Range, Wyo. and Utah (H. 6175b).

Iong-Leaf PINe (Pinus palustris).-At the Santee Club, South Carolina, fully 50 per cent of the long-leaf pines bear sapsucker work, some to a disfiguring degree, as protruding girdles have resulted. At Gainesville, Fla., sapsucker pecking is also plentiful on this species, but on St. Vincent Island, Fla., only a few trees are punctured. Hopkins notes that the sapsucker injures or kills roung trees. (His specimens are from Baldwin, Fla.; Boardman, N. C.; and Buna, Tex.) Ernest Napier, of the Game Commission of New 
Jersey, states that many young trees of this species in Lee County, Fla., have been killed by sapsuckers. The long-leaf pine is attacked throughout its range.

Pitch PINE (Pinus rigida).-Many trees of this species in the vicinity of Washington, D. C., show abundant evidence of sapsucker attack. A specimen from Delslow, W. Va. (H. 6653), is from a tree which was killed by yellow-bellied sapsuckers (Pl. V, fig. 6). The sapsucker pecks are in vertical rows and are so numerous and closely placed that nearly half the bark is remored. Pitch pines in Rockfish Valley, Va., also are attacked.

Poxd PINe (Pinus serotina).--Santee Club, South Carolina.

Short-Leaf PINe (Pinus echinata).--Hopkins states that young trees are injured or killed by sapsuckers. Specimens collected near Seven Locks, Montgomery County, Md., show that sapsucker injuries are sometimes followed by an attack of the fungus Peridermium cerebrum, causing large gall-like outgrowths which greatly disfigure the trees.

Spruce PINe (Pinus glabra).-Santee River, S. C. (A. M. 472).

Scrub PINe (Pinus virginiana).-The statement regarding fungus attack in echinata applies also to this species, which we know to be punctured by sapsuckers at Morgantown, W. Va. (H.), and in the vicinity of the District of Columbia. A dead tree on Plummers Island, Md., showed a band 8 to 10 inches wide of closely set punctures, and in other parts of the tree vertical strips of the bark had been remored. Death may well have been due to the sapsucker injuries.

Table-mountaix PINe (Pinus pungens).-Fairfax County, Va.

Austrian pine (Pinus laricio austriaca).-This species is widely. used for ornamental planting in the United States. It is often disfigured or even killed by the yellow-bellied sapsucker. Widmann (see Bendire) says it is the bird's "favorite tree among our ornamental evergreens. ... The exudations of resin, the secondary result of the sapsucker's labors, mar the appearance of the trees by running down their sides or hardening into unsightly lumps." Clifford states that the sapsuckers "do great damage to the .. . Austrian pines, sometimes girdling them so as to kill them," and Purdy notes that this species is one of the sapsucker's preferred food trees. An Austrian pine in the Department of Agriculture grounds bears considerable sapsucker work. Some of the pits are exceptionally large, and many are arranged in vertical rows. Dr. A. K. Fisher says that one of 7 or 8 Austrian pines at his old home in Ossining, N. Y., was favored by sapsuckers and worked upon extensively every fall.

Scotch PINe (Pinus sylvestris).-This tree is occasionally planted for ornament and suffers from sapsuckers almost as severely as the Austrian pine. Widmann (see Bendire) says the Scotch pine is the 
birl's second choice among our ornamental evergreens. The trunks and larger limbs . . . look very badly at times." Purdy notes that the Scotch pine is a favorite with the sapsuckers, and Clifford states that the birds sometimes kill it.

European lakch (Larix decidua).-Massachusetts, Kennard.

Nonway spruce (Picea excelsa).-This tree is extensively planted for ornamental purposes. Accorling to Elliott, the sapsucker "in its fondness for cambium often removes considerable fresh bark. I have seen several fine Norway spruces ruined in this way."

RED spruce (Picea rubens).-Randolph County, W. Va. (F. $74878)$; Davis, W. Va. (II. 6626b).

Exgelmane spruce (Picea engetmanni).--Sandpoint, Idaho (H. 195a).

Wenping spruce (Picea breweriana).-Northern California (A. M. $457)$.

'Tideland spruce (Picea sitchensis).-Push, Oreg. (II. 121a).

Eastern пiemLock (Tsuga canadensis).-This graceful and stately tree, a gem among ornamental conifers, is not spared by sapsuckers. Allen says: "In Vermont where I have observed S. varius [the yellowbellied sapsucker] in abundance, no trees were so extensively perforated as the hemlock." Bendire says the sapsucker "is partial to the ... hemlock;" and Hopkins notes that the bird injures or kills young trees. (Specimens from Allegheny Mountains, W. Va.)

Southern hemlock (Tsuga caroliniana).-South Carolina (A. M. 454); Habersham County, Ga., December 18, 1909 (F.).

Westeri nemlock (Tsuga heterophylla).-Detroit, Oreg., June 2, 1899 (H.); Hoquiam, Wash. (H. 2167a) (see Pl. VIII, fig. 3).

Dodglas FIr (Pseudotsuga mucronata).-St. Helena, Oreg. (H. 116a).

WiIte FIR (Abies concolor).-Oregon (A. M. 444); San Bernardino Mountains, Cal. Grinnell.

Winte Fin (Abies grandis).-Oregon (A. M. 446); McCloud, Cal. (H. 21).

White FIR (Abies amabilis).-Oregon (A. M. 447).

REI) Fir (Abies magnifica).-California (A. M. 441).

RED FIn (Abies nobitis).-Oregon (A. M. 442).

Big tree (Sequoia washingtoniana).-Near Grant National Park, Cal. (A. A. and A. M., 438).

REDwoOd (Sequoia sempervirens).-Eureka, Cal. (H.).

BAlD CYPRess (Taxodium distichum).-Boardman, N. C., March 25 and April 3, 1904 (II.); Cottonport, La., Longbridge, La.

INCENSE CEDAR (Heyderia decurrens).-Oregon (II.).

Canoe cedar (Thuja plicata).-Washington, May 3, 1899 (II.).

Monteney cypress (Cupressus macrocarpa).-Monterey, Cal. (A. II. 432). 
Gowex cypress (Cupressus goveniana).-California (A. M., 430).

Macxab crpress (Cupressus macnabiana).-Lake County, Cal. (A. M. 429).

White CEDAR (Chamæcyparis thyoides).-Dismal Swamp, Ta. November 21, 1901 (H.); Atsion, N. J. (A. M. 428).

Desert JUNiper (Juniperus utahensis).-Utah (A. A. and A. M. 422).

Westery Juxiper (Juniperus occidentalis).-California (A. M. 420). Rock CEDAR (Juniperus mexicana).-Austin, Tex. (A. M. 418.)

NORTHERx RED CEDAR (Juniperus virginiana).-This species is commonly attacked by sapsuckers. Mr. J. M. Thompson states that it is one of the bird's principal food trees, and Mr. F. K. Steere says it is often badly hurt by the sapsucker (letter from Annapolis, Md., Aug. 24, 1855). Of 40 red cedar trees on a part of Plummers Island, IId., 19 are covered with closely set sapsucker punctures. Specimens from Florida (A. M. 417); Kanawha Station, W. Ta. September 2S, 1903 (H.); and Illinois (F. 26487) show abundant sapsucker work.

SOUTHERx RED CEDAR (Juniperus barbadensis).-Jacksonville, Fla. (A. M. 416).

THE POPLARS AND WILLOWS (SALICACEE).

There are 15 native species of poplar in the United States, 8 of which, besides 1 introduced tree, are known to be attacked by sapsuckers. The only instance of serious injury to poplars that has come to notice was communicated rerbally by Prof. Cooke of the Biological Surrey. He states that in northern Minnesota, where the yellow-bellied sapsucker is common in summer, it kills many large poplar trees in the forests.

Willows are often seriously injured. Hopkins says the sapsucker injures or kills young trees, and specimens of small willows (Pl. V, fig. 5) collected by him in the Black Hills, S. Dak., September 3, 1901, show almost complete barking. Grinnell reports that sapsuckers kill many white willows (Satix lasiolepis). Fifteen of the 26 native arborescent willows are known to be attacked.

The injury to willows and poplars by sapsuckers is unfortunate, since these trees are valuable for shade, for ornament, and for protecting the banks of water courses.

LIST OF SALICACEE ATTACKED.

Silver poplar (Populus alba).-Washington, D. C., April 26, 1903 (H.); Albany, N. Y., Hough: Racine, Wis., Hoy, 1865.

SwaMP POPLAR (Populus heterophylla).-Louisiana or Alabama, (A. A. and A. M. 378). 
Black cottonwoon (Populus trichocarpa).--Seattle, Wash. (A. A. and 1. M. 373).

Balm of Gilead (Populus candicans).-New Hampshire (A. A. and A. M. 377).

Cotronwoon (Populus acuminata).-Nebraska (A. M. 374).

'Tacmanac (Populus balsamifera).-Essex County, N. Y. (A. A. and A. M. 376); Lewis County, N. Y. (Hough).

Carolina poplar (Populus deltoides).-Texas (A. M. 372); Venice, La.

Aspex (Populus grandidentata).-Rawdon, Nova Scotia (A. M. 379). Aspex (Populus tremuloides).-Mackenzie Valley, Canada (E. A. Preble).

Buack Willow (Salix nigra).--Belle Isle, La.

Ward Whlow (Salix longipes).-St. Louis, Mo. (A. A. and A. M. $368)$.

Calfforna black willow (Salix lærigata).-California (A. A. and 1. M. 366).

Willow (Salix toumeyi).-Santa Catalina Mountains, Ariz. (A. A. and A. M. 365).

Peach-Leaved willow (Salix amygdaloides).-New Mexico (A. A. and A. M. 367).

Westers black willow (Salix lasiandra),-California (A. A. and A. M. 362 and A. M. 364).

Sandbar willow (Salix interior).-New Orleans, La. (A. M. 360). Silver-leaved willow (Salix sessitifolia).-California (A. A. and A. M. 359).

Willow (Salix missouriensis).-Furness, Nebr. (A. M. 356).

White Willow (Salix lasiolepis).-California (A. A. and A. M. 357). According to Britton, the name Satix bigelovii is a synonym of $S$. lasiolepis. Hence the following note is incorporated here (see Pl. VI) :

Near Bluff Lake [Cal.] a species of willow (Salix bigclovii) grows in good-sized clumps... and these willows seem to offer special attraction to the sapsuckers. But curiously enough the attentions of the birds are confined to a single clump in a locality. .. . The incisions in the bark were generally rectangular, the long axis lorizontal, and in vertical rows. These up-and-down rows of incisions often ran tugether, making vertical grooves, and sometimes also the rows were so close together as to obliterate the interval, so that the bark was completely gone over a considerable space The trunk above this zone of attack was always partly or entirely dead.

This single willow dump . . . was rendered conspicuous by all its upper branches and stalks, above 2 to 4 feet from the ground, being lead, with the bark weathered off and the stems left hare and shining. (Grinnell, 1908.)

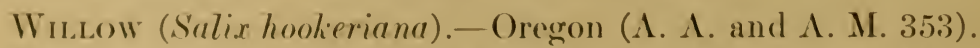

YEW-LEaven Whlow (Salix taxifolia).-Swisshelm Mountains, Ari\%. (A. A. and A. M. 35s and A. M. 361).

Satro whlow (Salix sitchensis).-California (A. A. and A. M. 352). 


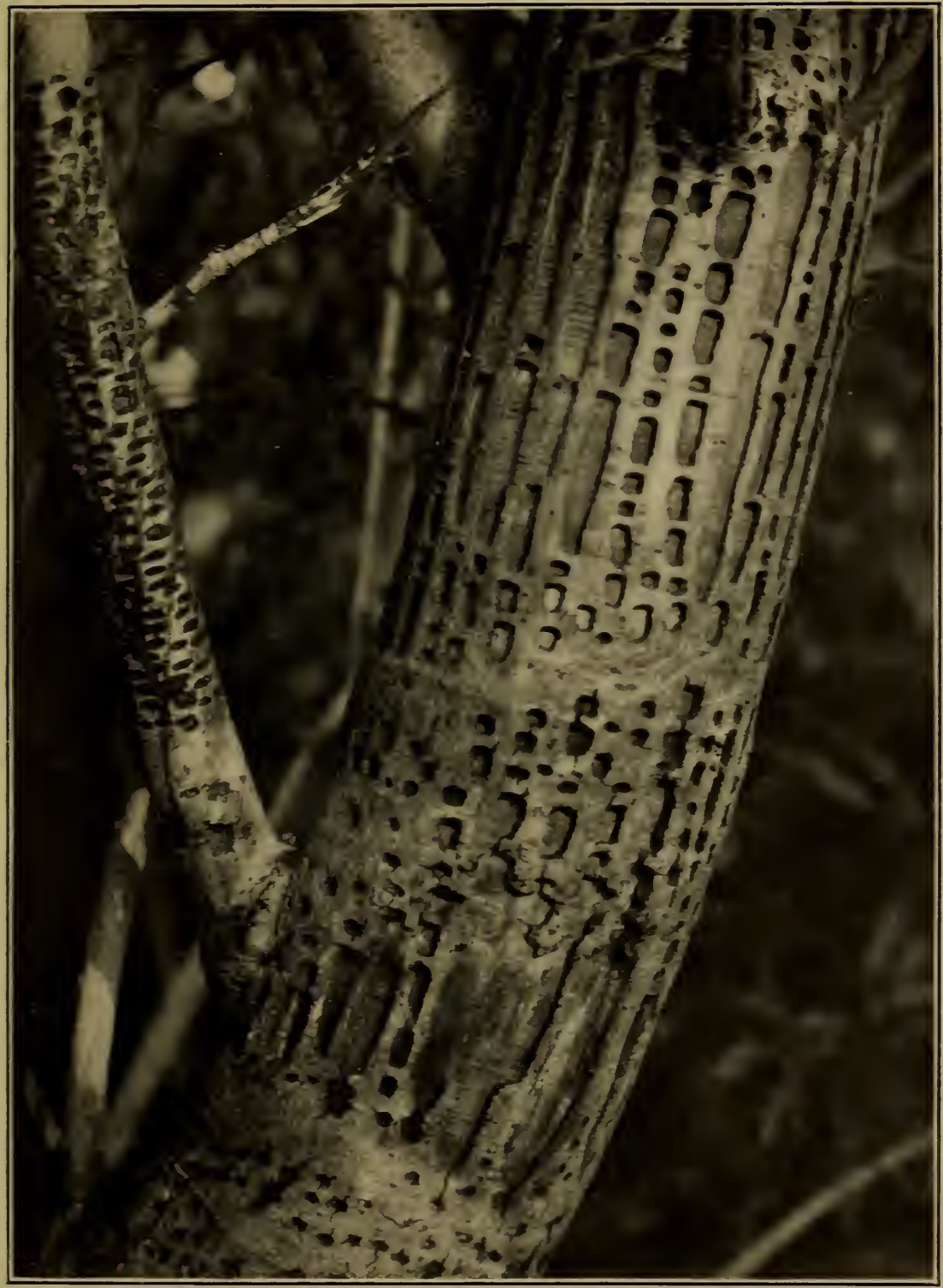

WORK OF SAPSUCKER ON WILLOW.

[Sierra sapsucker (Sphyrapicuz $r$. daggetti at Bluff Lake, California, September 3, 1905. BY J. Grinnell.] 

Glaucous willow (Salix discolor).-Vermont (A. A. and A. M. $355)$.

Willow (Salix scouleriana).-Oregon (A. A. and A. M. 354).

\section{THE BAYBERRIES (MYRICACE.E).}

There are four arborescent species ${ }^{1}$ of this family in the United States, of which three are known to be attacked by sapsuckers, one at least being sometimes in part or entirely killed. Howerer, these small trees hare slight economic ralue and are little used for ornamental planting.

LIST OF MYRICACE.E ATTACKED.

BAYBERRY (Myrica carolinensis).-Church Island, N. C.

WaX Myrtle (Myrica cerifera).-Florida (A. M. 384); Santee Club, South Carolina.

Califorta bayberry (Myrica californica),-California (A. M. $382)$.

THE WALNUTS AND HICKORIES (JUGLANDACEE).

Sapsuckers are known to attack 3 of the 5 native species of walnut besides 1 introduced species, and 11 of the 14 native hickories. Throughout their range hickory trees usually are sererely attacked by sapsuckers. We know of but one hickory being killed, but they are often disfigured by swollen girdles. Sapsuckers cause much staining and distortion in the wood of hickories.

LIST OF JUGLANDACE.E ATTACKED.

Butternet (Juglans cinerea).-Fairfax County, Va.

BLACK Walxet (Juglans nigra).-Allenton, Мo. (A. M. 399); Indianapolis, Ind. (H. 24236); Rockfish Valley, Va.; Beltsville, Md.

Texan walvet (Juglans rupestris).-Arizona (A. A. and A. M. 395).

Exglish waldet (Juglans regia). - A tree on the grounds of the Department of Agriculture in Washington bears profuse eridence of sapsucker work. One limb has been killed on one side.

NutMeg hickori (Hicoria myristicæformis).-Oakley, S. C. (A. M. $392)$.

PeCax (Hicoria pecan).-Butler County, Мo. (F. 72458); Illinois (F. 26454); Allenton, MIo. (A. A. and A. M. 395); Pantherburn, Miss.; Department of Agriculture grounds, District of Columbia.

Texax pecax (Hicoria texana).-Columbia, Tex. (A. A. 394).

1 Only 3 arborescent species are mentioned in Britton's North American Trees, but 3 fyrica carolinensis Miller (= Myrica cerifera intermedia Chapman, fide Sudworth) is typically tree-like on the shores of Currituck Sound, N. C. 
Bitter pecan (Hicoria aquatica).--Southern Arkansas (A. A. and A. M. 391); (ot tonport and Longbridge, La.

BItTer Nut (Hicoria cordiformis).-West Virginia (F. 73488); Allenton, Mo. (A. A. and A. M. 393): Seren Locks, Montgomery County, Md.; Department of Agriculture grounds, District of Columbia.

Mocker vut (Hicoria alba).-This species is very commonly attacked by sapsuckers. A tree in Fairfax County, Va., examined March 21, 1909, bore many protruding girdles (Pl. X, fig. 1) where the birds had pecked in the same place year after year, besides a great deal of less conspicuous work. Plate IX, figure 2, shows similar girdles on another tree which is fully 2 feet in diameter. At the date specified there were many fresh drills in the girdles and elsewhere, and sap was flowing freely. Evidently growth is vigorous in this species, as a plug of wood grows out through almost every hole in the bark. About all the sapsucker has to do when he visits the tree the next year is to knock out the plugs. However, he usually punctures a layer or two of sapwood to insure a good flow of sap. A dead tree of this species near the same locality was evidently killed by sapsuckers. It bore more than a hundred nearly or entirely complete girlles of holes, besides numerous less perfect ones. In fact it was riddled from bottom to top. (Pl. IX, fig. 3.) From an examination of sections of this tree it was learned that all this work has been done in five years or less. Much of it never healed. The mocker nut is severely attacked in the vicinity of Cloverdale, Ind. (letter from J. B. Burris, Dec. 9, 1901), and to some extent also in Illinois (F. $26457)$.

Big Shellbark (Iicoria laciniosa).-Morgantown, W. Va. (H.); Illinois (F. 26458); Department of Agriculture grounds, District of Columbia.

Sinellbark (Hicoria ovata).-Widmann (see Bendire) notes that this species is "occasionally punctured." A specimen from Butler County, Mo., shows many pecks (F. 72449), and a tree in the Agriculture Department grounds at Washington has on the limbs many sapsucker girdles, which cause the bark to split and peel off more than it naturally would.

Southern SHELlbark (IIicoria carolinæ-septentrionalis).-Rome, Ga. (1. M.).

Pignut (Ificoria glabra).-Weed and Dearborn state that sapsuckers "puncture the pignut hickory," and C. G. Bates says:

Bird perks are common almost everywhere that hickories are found, but perhaps nowhere is the damage so serious as on the southerly slopes of the Cumberland Mountains of Temnessee, where the hickory, mostly pignut, occurs in rather open stands with rhestnut oak, which is also frequently attacked by the sapsucker. (Dec. 15, 1908.) 
Specimens from Butler County, Mo. (F. 72438), and Abbeville, La., show profuse sapsucker work, including large swollen girdles. A tree only an inch in diameter, on Plummers Island, Md., had been attacked br sapsuckers.

Woolly pignet (Hicoria villosa).-Huntsville, Ala. (A. A. and A. M. 385).

THE HORNBEAMS, BIRCHES, AND ALDERS (BETLLACE王).

Ten of the 26 native arborescent species of this family, besides 1 introduced tree, are known to be attacked by sapsuckers. They are tabulated by genera below:

\begin{tabular}{|c|c|c|c|}
\hline Genus. & $\begin{array}{l}\text { Number } \\
\text { of native } \\
\text { species. }\end{array}$ & $\begin{array}{l}\text { Native } \\
\text { species } \\
\text { attacked. }\end{array}$ & $\begin{array}{l}\text { Introduced } \\
\text { species } \\
\text { attacked. }\end{array}$ \\
\hline \multirow[t]{2}{*}{ 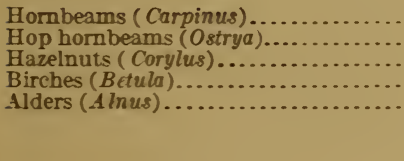 } & $\begin{array}{r}1 \\
2 \\
1 \\
14 \\
8\end{array}$ & $\begin{array}{l}1 \\
2 \\
0 \\
5 \\
2\end{array}$ & $\begin{array}{l}1 \\
0 \\
0 \\
0 \\
0\end{array}$ \\
\hline & 26 & 10 & 1 \\
\hline
\end{tabular}

Two of the hornbeams and two hop hornbeams are much disfigured by sapsuckers, and at least two species of birches are frequently killed. Trees like the hornbeams with smooth close bark, and birches, which are prized for the beauty of their silvery white trunks, lose much of their ornamental value when disfigured by abundant sapsucker puncturing. Birches in particular are among the most raluable ornamental trees, and the fact that they are often killed by sapsuckers weighs heavily against the birds.

\section{LIST OF BETULACE.E ATTACKED.}

Horvbean (Carpinus caroliniana).-This tree when attacked is generally severely blemished (fig. 6). One in the Agricultural Department grounds is disfigured by a great many girdles, some of which are considerably swollen. In the vicinity of Gainesrille, Fla., hornbeams are plentifully punctured, and at Abberille, La., most of the hornbeams in the woods bore abundant sapsucker work. Specimens examined from Illinois (F. 26482), Morgantown, W. Va. (H.), and southern Arkansas (A. A. 351) are profusely punctured.

Ecropeax horsbeam (Carpinus betula).-Department of Agriculture grounds, District of Columbia.

Hop HORxbeaM (Ostrya virginiana).-Morgantown, W. Va. (H.); Massachusetts (A. A. and A. M. 3.50).

Hop HoRxbeair (Ostrya knowltoni).-Talfrey, Ariz. (A. A. and A. M. 349). 
Gray birch (Betula populifolia).-Department of Agriculture grounds, District of Columbia.

White or CaNoe вiRch (Betula alba).-This tree is frequently and seriously injured by sapsuckers (Pl. V, fig. 2). Weed and Dearborn say that "hundreds of punctures" are "made in white birches" and Hopkins notes that the sapsucker injures or kills young trees. Bolles, in writing of a sapsucker "orchard," states that "The tree in use last year" was nearly dead. Two neighboring birches showing scars of earlier years were quite dead. . . . Orchard No. 4 . . consisted of a large number of dead and a few living trees. ... The part of the orchard in use was a birch, from whose roots rose 4 major trunks quickly subdividing into 15 minor stems each ris-

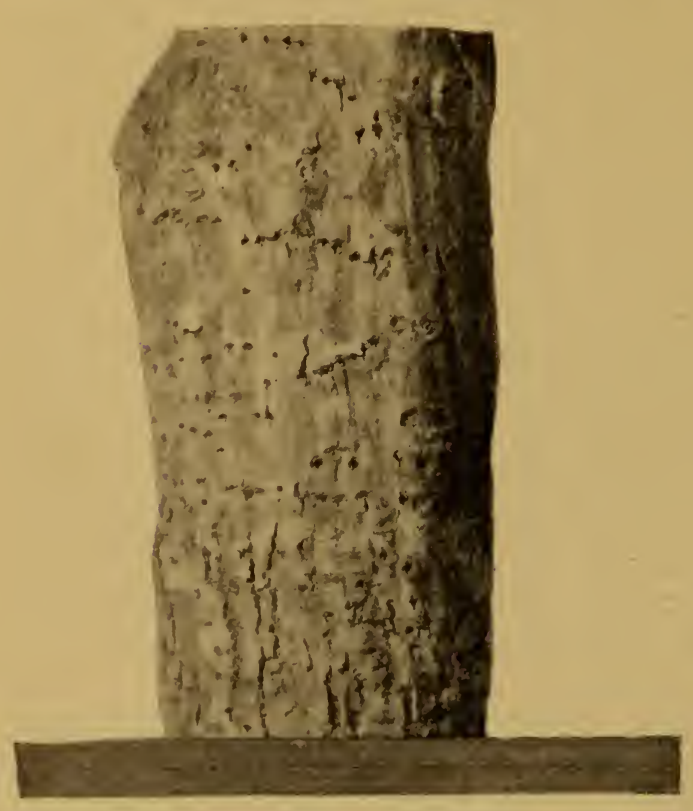

Fig. 6.-Sapsucker work on hornbeam (Carpinus caroliniana). ing to a height of over 30 feet. All of the 15 trunks were dead or dying. Only 7 of them bore leaves." "Hermit," speaking of a sapsucker "orchard," says: "The . . canoe birches were dead or dying. Many . . . had been broken off by the wind just below the belt of punctures." Horsford says: "I have seen the white birch cut off, or rather broken off, 20 feet from the ground, in more cases than I can number, all his work. ... The birch tree invariably dies." And Garfield notes that "This bird invariably attacks what appears to be perfectly sound and healthy bark. Great injury is inflicted by these attacks. . . . The white birch is frequently killed." George H. Selover writes that sapsuckers have often killed silver birches at Lake City, Minn. (letter, 1SS.5). The tree is attacked in Maine also (H.).

Winte вівсі (Betula pendula).-Department of Agriculture grounds, District of Columbia.

Cherrir birch (Betula lenta).-West Virginia (H.).

Yezuow minci (Betula lutea).-The sapsucker "is partial to the . . . yellow birch" (Bendire), and it "injures or kills young trees" (Hopkins). William Brewster says that the yellow birch is very 
commonly attacked in western Maine, and Horsford states: "I have seen the yellow birch destroyed ... branches of the tree cut off, shriveled branches struggling for life, but dying."

Alder (Alnus incana).-A. A. 340; western Maine, William Brewster.

White Alder (Alnus rhombifolia).-San Bernardino Mountains, Cal., Grinnell.

\section{THE BEECHES, CHESTNLTS, AND OAKS (FAGACEæ).}

Thirty-four of the 68 native arborescent species of this important family of trees and 2 introduced forms are known to be attacked by sapsuckers. Usually the injury does not seem to affect the vigor of oaks, and we know of few instances of the external appearance of the trees being altered for the worse. A sample of a dying live oak, sent to the Bureau of Entomology from Glen Rose, Tex., shows no injury except by sapsuckers, and Bolles implies that red oaks are sometimes killed. On the whole, the evidence at hand, while showing that a large number of species of this family are attacked by sapsuckers, does not indicate serious injury to their appearance or health.

\section{LIST OF FAGACEE ATTACKED.}

BeEch (Fagus grandifolia).-Morgantown, W. Va. (H.); Rawdon, Nora Scotia (A. A. and A. M. 334); Massachusetts, Weed and Dearborn.

Chinquapin (Castanea pumila).-Southern Arkansas (A. A. and A. M. 332).

Chestrut (Castanea dentata).-Pickens, W. Va. (II. 6687a); Townsend Center, Mass. (A. M. 333); Montgomery County, Md.; Afton and Rockfish Valley, Va.

TANBARK OAK (Pasania densiflora).-Hopkins.

RED OAK (Quercus rubra).-Bendire remarks that sapsuckers are "partial to the ... red oak," and Bolles says it is "drilled for successire years," adding that "the forest trees attacked by them generally die." Five red oaks in the Department of Agriculture grounds show sparing sapsucker work; many trees about Afton, Va., are attacked, and a specimen from Allenton. Mo., shows that the tree is visited there also (A. M. 329).

PIx OAK (Quercus palustris).-Every tree of this species orer a considerable area in the vicinity of Dead Run Swamp, Fairfax County, Va., bears profuse marks of sapsucker attack.

TURKEY OAK (Quercus catesbæi).-Florida (A. M. 322).

BLACK OAK (Quercus velutina).-Abbeville, La.

Texas OAK (Quercus texana).-Abbeville, La.

$99068^{\circ}-$ Bull. $39-11-3$ 
SCARLET OAK (Quercus coccinea).-Department of Agriculture grounds, District of Columbia.

SPANish OAK (Quercus triloba).-Florida (A. M. 321).

Swamp Spanish оак (Quercus pagodrefolia).-Abbeville, La.

Water OAK (Quercus nigra).--Illinois (F. 26474); Santee Club, South Carolina.

WiLlow олк (Quercus phellos).-Missouri (A. M. 317); Departof Agriculture grounds, District of Columbia.

LAUREI, OAK (Quercus laurifolia).-Abbeville, La.

Shingle OAK (Quercus imbricaria).-Missouri (A. M. 313); Department of Agriculture grounds, District of Columbia.

White-LeAf OAK (Quercus hypoleuca).-Southern Arizona (A. M. 30 S).

California live OAK (Quercus agrifotia).-Newhall, Cal. (A. M. $312)$.

White LIVE oAK (Quercus chrysolepis).-California (A. A. and and A. M. 306).

LIVE OAK (Quercus virginiana).-Fully 90 per cent of the live oaks at the Santee Club, South Carolina, are abundantly pecked, some having protruding girdles. At Gainesville, Fla., a large proportion of the live oaks are punctured, generally profusely, while on St. Vincent Island, Fla., though many trees are pecked, the work is usually scanty. A specimen from Glen Rose, Tex. (presented by Dr. Hopkins, October 4, 1909), is rather closely punctured.

NeT-LEaf OAK (Quercus reticulata).--Southern Arizona (A. A. and A. M. 285).

Texan white oAK (Quercus breviloba).-Austin, Tex. (A. A. and A. M. 292).

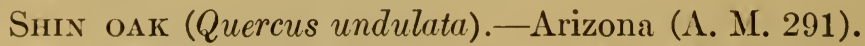

Toumey OАK (Quercus toumeyi).-Mule Mounitains, Ariz. (A. M. 286).

Chapman олк (Quercus chapmani).-Apalachicola, Fla. (A. A. and A. M. 299).

Chestrut on (Quercus prinus).-A sapling near the Seven Locks, Montgomery County, Md., shows considerable sapsucker work, which deforms its trunk. In the Cumberland Mountains of Tennessee this species is frequently attacked (C. G. Bates, Dec. 15, 1908), and a specimen in the Field Museum (No. 7296S) shows that it is worked on vigorously in West Virginia.

Cow o.K (Quercus michauxii).-Many trees of this species are abundantly punctured, frequently with unusually large holes (made necessary by the thickness of the bark) in the vicinity of Longbridge, Cottonport, and Abbeville, La.

SWAMP WHITE OAK (Quercus bicolor).-Missouri (A. A. 296); Department of Agriculture grounds, District of Columbia. 
Overcup OAK (Quercus lyrata).- Southern Arkansas (A. M. 297); Illinois (F. 26519); Butler County, Mo.'(F. 72988); Department of Agriculture grounds, District of Columbia.

Califorila White oAK (Quercus lobata).-California (A. M. 303). Westers White oAK (Quercus garryana).-Grant Pass, Oreg., April 25, 1899 (H.); California (A. M. 302).

Colorado White oAK (Quercus leptophylla).-Colorado (A. A. and A. M. 301).

Post оАК (Quercus stellata).-Missouri (A. M. 300); Santee Club, South Carolina; Longbridge, La.

White OAK (Quercus alba).-White oaks show more eridence of sapsucker attack than any other species of the genus in the vicinity of Washington. In some localities large numbers of the trees are closely punctured and girdled. Sapsucker work is very common on this species about Afton, Va., and the tree is attacked also in West Virginia (H.) and near Winston-Salem, N. C.

ExGLISH OAK (Quercus robur).-Specimens of the horticultural variety of this species known as Quercus sessitiflora cochleata, the subspecies pedunculata, and its cultivated form incisa, five trees in all, on the grounds of the Department of Agriculture, bear rather abundant puncturing.

Europeax OAK (Quercus conferta and var. pannonica).-Department of Agriculture grounds, District of Columbia.

\section{THE ELMS AND HACKBERRIES (ULMACEE).}

This family comprises 17 native trees belonging to 4 genera. Eight of the native species and 2 introduced forms are known to be attacked by sapsuckers. Disfiguring swollen girdles hare been noted on 2 species of elm and 1 of hackberry, and 1 of the elms is said to be reduced in rigor by excessive pecking.

\begin{tabular}{|c|c|c|c|}
\hline Genus. & $\begin{array}{l}\text { Number } \\
\text { of natire } \\
\text { species. }\end{array}$ & $\begin{array}{l}\text { Natire } \\
\text { species } \\
\text { attacked. }\end{array}$ & $\begin{array}{l}\text { Introduced } \\
\text { species } \\
\text { attacked. }\end{array}$ \\
\hline \multirow[t]{2}{*}{ 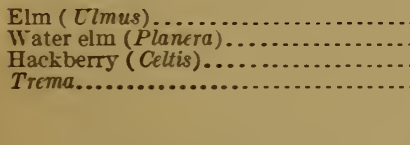 } & $\begin{array}{l}6 \\
1 \\
9 \\
1\end{array}$ & $\begin{array}{l}5 \\
1 \\
2 \\
0\end{array}$ & $\begin{array}{l}2 \\
0 \\
0 \\
0\end{array}$ \\
\hline & 17 & 8 & 2 \\
\hline
\end{tabular}

LIST OF ULMACE.E ATTACKED.

Cedar elm (Clmus crassifolia).-Matteson, Miss. (F.).

Rock ELM (Ulmus thomasi).-Lansing, Mich. (A. M. 2S0).

Wivged ElM (Clmus alata).-Aiken, S. C. (A. M. 281).

White ELM (Clmus americana).-Bendire remarks that the sapsucker "is partial to the ... elm;" and Horsford says: "I have 
seen an elm tree 18 inches in diameter whose trunk of 12 feet was spotted with 'gimlet holes' in the bark nearly 1 inch thick, and where for 10 summers past I have shot the pests and thereby saved the tree." A white elm in the Smithsonian grounds is much disfigured by sapsucker girdles and one near Scotts Run, Fairfax County, Va., bears more conspicuous work of the same character, some of the girdles being 3 feet long and gaping as much as 3 inches (Pl. VII, fig. 2). Specimens examined show that the tree is attacked in West Virginia (H.), Illinois, and in Butler County, Mo. (F. 26445 and 73249, respectively).

SLIPPERY ELM (Ulmus fulva). - Specimens examined show that this species is attacked by sapsuckers in Missouri (A. M. 278) and West Virginia (II.). Sapsucker work was noted on slippery elms near Abbeville, La., and trees seen near Longbridge, La., were covered with rows of punctures, some of which had swollen into projecting girdles.

Exglish ela (Ulmus campestris) and Scotch fla (Ulmus montana).- In the Agricultural Department grounds are 31 elms, 9 of which are marked by sapsuckers. Some are profusely punctured and both of the European species, as well as the American elm, are attacked.

WATER Elar (Planera aquatica).-Arkansas (A. A. and A. M. 275).

ПАсквеRкY (Celtis occidentalis).-Iron County, Mo. (F. 72268); Allenton, Mo. (A. M. 273).

IАCKвеRRY (Celtis mississippiensis).-Sapsucker pecking is very abundant on trees of this species in the vicinity of ('ottonport and Longbridge, La. A peculiar effect of sapsucker work on this tree is that rings of bark are often formed about the punctures. They may be half an inch in height, and as they are round and open, a cluster of them on the gray bark forms a model in miniature of a colony of cliff swallows' nests.

\section{THE FOLR O'CLOCK FAMHLY (NYCTAGINACEe).}

The single arborescent species in our flora is attached by sapsuckers.

Blolly (Tomubia longifolia).-Florida Keys (A. M. 264).

\section{THE MagNolias AND TUlip TREes (MAgNoliaCEA).}

Six of the 8 native magnolias, 3 introduced species, and the single native species of tulip trees are distinct favorites of the birds. Of 22 magnolias on the Department of Agriculture grounds half have been pecked. The resulting girdles in the smooth, ashy gray bark of some of the species are unsightly, and one of the trees, a bull bay, is much roughened and distorted. The tulip tree is attacked thoughout its 


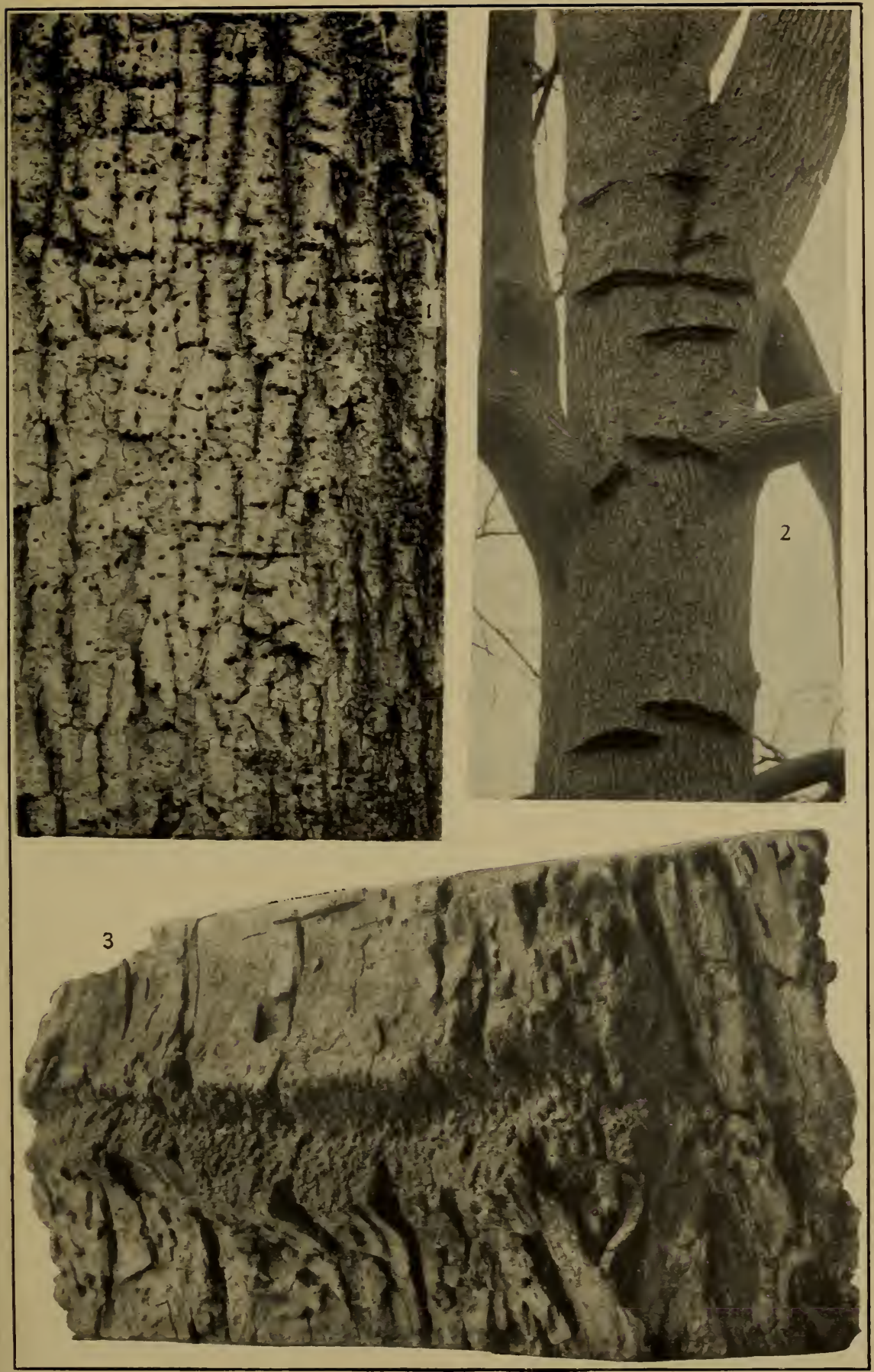

WORK OF SAPSUCKER ON WHITE ELM.

[1, Near view of bark showing closeness of punctures. 2, View of trunk showing swollen girdles (second one abore limbs is about 3 feet long). 3 , Near view of part of this girdle.] 

range, but we know of no case where this species has been killed by sapsuckers. One of the magnolias, however, seems to be more seriously affected.

LIST OF MAGNOLIACEE ATTACKED.

Cucumber tree (Magnotia acuminata).-Trees of this species in the grounds of the Department of Agriculture are plentifully punctured by sapsuckers, but the work is inconspicuous in their rough bark. All cucumber trees observed in the upper part of Rockfish Valley, Va., bore sapsucker work, one having several large swollen partial girdles. The species is attacked in West Virginia also (H.).

Mountain Cucumber tree (Magnolia cordata).-Department of Agriculture grounds, District of Columbia.

BULL BAY (Magnotia grandiflora).-Many of the trees bordering a long arenue at the Santee Club, South Carolina, bear sapsucker work. Trees in the vicinity of Longbridge, La., are abundantly punctured, and two specimens in the grounds of the Department of Agriculture at Washington have been attacked, one so vigorously that it is disfigured by numerous girdles. L. L. Wright, of Talladega, Ala., sent in a specimen of sapsucker work from a tree of this species which, he writes, is dying from the effects of whatever it is that is "honeycombing" the bark. From about 2 feet above the ground to the top of the tree it has been girdled at intervals of 15 to 24 inches, the holes varying from contact with each other to three-fourths of an inch apart. At about 8 feet above the ground a double girdle of holes has been made about an inch apart, and so deep as to remore the entire inner bark except for about 6 inches out of a circumference of nearly 3 feet. (March 18, 1911.)

SweEt BAY (Magnolia virginiana).-Department of Agriculture grounds, District of Columbia; Church Island, N. C.

UMBRella tree (Magnolia tripetala).-Illinois (F. 26401).

LARGE-LEAVEd umbrella TREe (Magnolia macrophylla).-Department of Agriculture grounds, District of Columbia.

East Asian magnolia (Magnolia yulan).-Department of Agriculture grounds, District of Columbia.

East Asian magnolia (Magnolia obovata).-Department of Agriculture grounds, District of Columbia.

East Asian magnolia (Magnolia hypoleuca).-Department of Agriculture grounds, District of Columbia.

TULIP TREE (Liriodendron tulipifera).-This species is a distinct favorite with sapsuckers. Everywhere about Washington are trees bearing abundant sapsucker work. The same is true in the vicinity of Winston-Salem, N. C., and the tree is vigorously attacked in the Rockfish Valley, Va., in West Virginia (Delslow, H. 6687; Pickens, H. 6487a), and in Illinois (F. 26403). 


\section{TIIE PAWPAWS ANI PONI APPLES (ANONACEE).}

'Two genera, each represented by one arborescent species, occur in the United States. One of these species, the pawpaw, is attacked by sapsuckers, but, so far as known, not seriously injured.

PAWPAW (Asimina triloba).-Arkansas (A. M. 255); Illinois (F. 26404); Fairfax County, Va.

\section{THE BAYS AND LAURELS (IAURACEA).}

The following tabulation shows the arborescent members of this family in the United States and the number of species attacked by sapsuckers:

\begin{tabular}{|c|c|c|c|}
\hline Genus. & $\begin{array}{l}\text { Number of } \\
\text { native } \\
\text { species. }\end{array}$ & $\begin{array}{l}\text { Native } \\
\text { species } \\
\text { attacked. }\end{array}$ & $\begin{array}{l}\text { Introduced } \\
\text { species } \\
\text { at taeked. }\end{array}$ \\
\hline 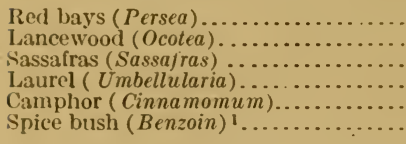 & $\begin{array}{l}3 \\
1 \\
1 \\
1 \\
0 \\
1\end{array}$ & $\begin{array}{l}2 \\
0 \\
1 \\
1 \\
0 \\
0\end{array}$ & $\begin{array}{l}0 \\
0 \\
0 \\
0 \\
1 \\
0\end{array}$ \\
\hline & 7 & 1 & 1 \\
\hline
\end{tabular}

1 Not usually classed as arborescent, but according to Dr. 1. K. Fisher it hecomes a tree in Fairfax County, Va.

Sassafras and camphor trees are known to be killed by the birds and all of the other species attacked are badly disfigured. These trees are used for ornament, and sapsucker injury to them counts against the bird.

\section{LIST OF LAURACE.E ATTACKED.}

RED BAY (Persea borbonia).-Apparently all trees of this species in the vicinity of the Santee Club, South Carolina, are attacked by sapsuckers. Most of them are profusely punctured, and the exterior of one tree was much disfigured by numerous rings of pecks which had become swollen and produced gaping, knotty girdles. At Gainesville, Fla., a large proportion of the red bays bore abundant sapsucker work.

SwaMP red baY (Persea pubescens).-Trees of this species also were vigorously attacked near the Santee Club, South Carolina.

Sassafras (Sassafras variifolium).--The sapsucker injures or kills young trees (Hopkins). (Specimen from Monongalia County, W. Va., Mar. 17, 1894. Pl. XI, fig. 4.)

California laurel (L'mbellularia californica): - A specimen from California stows evidence of severe sapsucker attack (A. A. 250). 
CAMPhor tree (Cinnamomum camphora).-Camphor trees which were abundantly punctured were observed at Gainesville, Fla., and at Abbeville, La., the writer was informed that two eamphor trees planted near that town had been killed by sapsuckers.

THE SWEET GUM FAMILY (ALTINGIACE.E).

Only one species of this family occurs in the United States. It is vigorously attacked by sapsuckers apparently throughout its range, but, so far as we know, is nerer killed.

SweEt gum (Liquidambar styraciflua).-A tree in the Agricultural Department grounds has a great many girdles of sapsucker pecks. At the Santee Club, South Carolina, almost erery sweet gum tree bear's sapsucker work, the bark of some being perforated as thickly as possible from top to bottom. At Gainesville, Fla., a large proportion of the trees are abundantly punctured, and the tree seems as much a farorite at Abbeville, La.

THE SYCAMORES (PlataxaCEe).

Two of the three native species are attacked by sapsuckers,

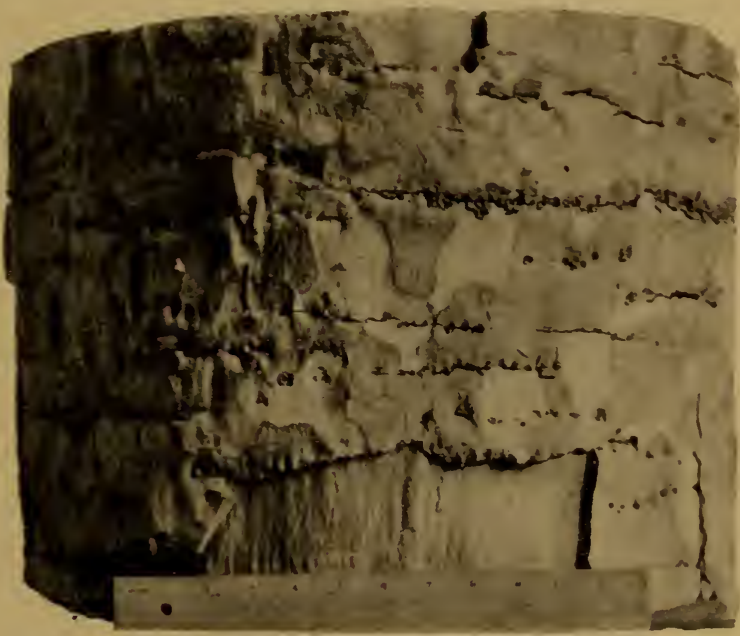

FIG. 7.-Sapsucker work on California sycamore (Platanus racemosa). and although the work disfigures the smooth white bark, it is not known to decrease the vitality of the trees.

LIST OF PLATANACEE ATTACKED.

Sycayore (Platanus occidentalis).-Longbridge, La.

Califoria sycamore (Platanus racemosa).-California (A. A. and A. M. 244). (Fig. 7.)

THE ROSE FAMILY (ROSACE.E).

All of the fire arborescent species of this family occurring in the United States are attacked by sapsuckers, and one (Cercocarpus ledifolius) is known to be much disfigured. 
LIST OF ROSACEA ATTACKED.

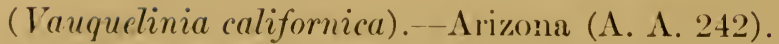

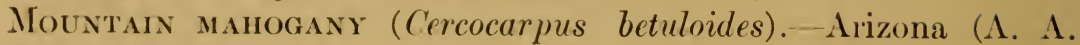
and A. M. 203).

Mountain mahogany (Cercocarpus traskiæ). - Santa Catalina Island, Cal. (A. A. 205).

Mountain mahogaxy (Cercocarpus breviflorus).-Huachucha Moun-

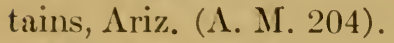

Mountain mahogany (Cercocarpus ledifolius).-Eureka, Cal. (A. A. 202).

THE APPLE FAMILY (MALACEE).

This family contains trees of immense economic importance, as the pear, crab apple, and apple. Each of these is attacked by sapsuckers. Both kinds of apple trees are often killed and young orchards are sometimes ruined. The apple family includes also valuable ornamental trees, which are often injured or killed, especially the mountain ash. The harm done to the trees of this family weighs heavily in the case against the sapsuckers.

Species of Malacex known to be attacked by sapsuckers.

\begin{tabular}{|c|c|c|c|}
\hline Genus. & $\begin{array}{c}\text { Number of } \\
\text { native } \\
\text { species. }\end{array}$ & $\begin{array}{c}\text { Native } \\
\text { species } \\
\text { attacked. }\end{array}$ & $\begin{array}{l}\text { Introduced } \\
\text { species } \\
\text { attacked. }\end{array}$ \\
\hline \multirow[t]{2}{*}{ 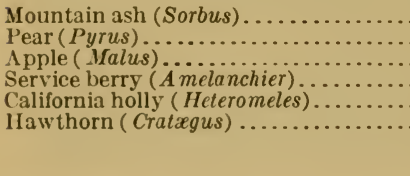 } & $\begin{array}{c}1 \\
0 \\
5 \\
6 \\
1 \\
50+\end{array}$ & $\begin{array}{r}1 \\
0 \\
3 \\
0 \\
1 \\
10\end{array}$ & $\begin{array}{l}2 \\
2 \\
0 \\
0 \\
2\end{array}$ \\
\hline & $63+$ & 15 & 6 \\
\hline
\end{tabular}

Our information as to the number of species of hawthorn attacked must be far less complete than that concerning other genera. Species of this genus have been described in recent years by the hundred. $\Lambda$ conservative author now recognizes 50 arborescent species in the Northeastern States, and as the genus seems to be a favorite with the sapsucker, it is probable that many more than the 10 species here recorded are attacked.

LIST OF MALACE.E ATTACKED.

Mountain ASH (Sorbus americana).-Bendire notes that the yellow-bellied woodpecker is "partial to the . . . mountain ash." Merriam says: "More than half the bark is sometimes removed from the grirlled portions, and the balance dries up and comes off. Therefore it is not surprising that trees which have been extensively girdled generally die." Warren notes that "in one garden [in Racine, Wis.], 
all the mountain ash . . . trees were entirely killed," and Dr. A. K. Fisher reports that sapsuckers killed a large mountain ash near Ossining, N. Y.

Pear (Pyrus communis).-Hoy (1865) states that this species is attacked by the sapsucker, and J.M. Thompson says the pear is "one of its principal food trees."

Olive-Leaved Pear (Pyrus elæagnifolia).-Department of Agriculture grounds, District of Columbia.

Crab apple (Malus angustifolia).- South Carolina (A. A. and A. M. 240).

Crab apple (Malus baccata).-Widmann (see Bendire) says this species is occasionally punctured, and Horsford states that "the sour puckery crab apple seldom escapes." He also figures a crab apple tree which was killed by yellow-bellied sapsuckers.

Crab apple (Malus coronaria).-Nazareth, Pa. (A. M. 239).

Apple (Malus malus).-Everywhere in the United States, apparently, apple trees are subject to sapsucker attack (see Pl. V, fig. 3). The writer has noticed abundant sapsucker work on trees in Massachusetts, Maryland, the District of Columbia, and Virginia. Near Afton, Va., fully 90 per cent of the trees in an orchard of 40 acres had been pecked profusely. The apple tree is attacked in Indiana and in West Virginia (Hopkins) and many other places mentioned in the following notes, often with fatal results. Bendire says the sapsucker "materially injures and eventually kills many... trees. In southern Utah ... it is said to do considerable damage to orchards in the early spring and again in fall, tapping the . . . apple trees for sap." Horsford says:

This is the most destructive bird in our climate. I have seen the best trees in an apple orchard destroyed. . . . Where the bird breeds, whole orchards are severely injured, if not destroyed, by them. . . . The flow of sap is so diminished that the leaves fade and the fruit withers on the stem or falls to the ground. Perhaps not half the apple trees attacked are killed outright. The injury is . . in every possible degree, from the round "gimlet hole," which is not fatal, to the broad "countersink," which kills the branch or the whole tree.

Garfield notes that "an apple tree badly pecked ceases to bear for several years." Clifford states that they "do great damage to the apple trees ... sometimes girdling them so as to kill them entirely," and George H. Selover writes: "The yellow-bellied woodpeckers . . . have been noticed very often in the act of picking through the bark of apple trees, and quite often have destroyed the trees" (Lake City, Minn., 1885).

Crab apple (Malus diversifolia).-Oregon (A. M. 238).

Califoria holly (Heteromeles arbutifolia).-A trunk collected in California is much deformed. One almost complete girdle of punctures retains the characteristic appearance, while elsewhere there are 
irregular swollen ridges covered by roughly fractured bark, but showing traces of regularly placed holes $(\Lambda$. $\Lambda$. and $\Lambda$. M. 235).

Hawtrorss (Cratogus).-Bendire says the sapsucker is "partial to the thorn apple," a statement fully justified. Out of a collection of 27 trunks of thorn trees in the American Museum, 13 were punctured. In the vicinity of Longbridge, La., practically all the haw trees (Cratxgus opima) were pecked by sapsuckers, many of them showing swollen girdles.

LIST OF HAWTHORNS ATTACKED BY SAPSUCKERS.

(Cratxgus crus-galli)-Marshall, Tex. (A. M. 229); (C. punctata)Georgia (A. A. 226); (C. lacrimata)-Crestview, Fla. (A. M. 212); (C. opima)-Longbridge, La.; $(C$. berlandieri)-Columbia, Tex. (A. M. 219); (C. boyntoni)-Asheville, N. C., (A. M. 215); (C. brazoria)-Brazoria, Tex. (A. M. 224); (C. collina)-Asheville, N. C. (A. A. and A. M. 225); (C. texana)-Columbia, Tex. (A. M. 218); (C. mollis)-Dallas, Tex. (A. M. 220); (C. marshalli)-South Carolina (A. M. 211); (C. monogyna)-Smithsonian grounds, District of Columbia.

\section{THE PLUMS AND CHERRIES (AMYGDALACEE).}

This family, lıke the preceding, contains species of great commercial valus-the peach, plums, and cherries. Two species of plums and one of cherry are known to be deformed by sapsucker work, and the cultivated peach and cherry are killed. Considerable damage is sometimes done to orchards of these trees.

Tabulation of Amygdalacea known to be attacked by sapsuckers.

\begin{tabular}{|c|c|c|c|}
\hline Genus. & $\begin{array}{l}\text { Number of } \\
\text { native } \\
\text { species. }\end{array}$ & $\begin{array}{l}\text { Native } \\
\text { species } \\
\text { attacked. }\end{array}$ & $\begin{array}{l}\text { Introduced } \\
\text { species } \\
\text { attacked. }\end{array}$ \\
\hline \multirow[t]{2}{*}{$\begin{array}{l}\text { ('ocoa plum ( Chrysobalanus)............ } \\
\text { P'each, plum, and cherry .............. } \\
\text { (irape cherries ( Padus)............ } \\
\text { Evergreen cherries (Laurocerasus) ..... }\end{array}$} & $\begin{array}{r}1 \\
14 \\
8 \\
4\end{array}$ & $\begin{array}{l}0 \\
6 \\
2 \\
1\end{array}$ & $\begin{array}{l}0 \\
4 \\
0 \\
0\end{array}$ \\
\hline & 27 & 9 & 4 \\
\hline
\end{tabular}

LIST OF AMYG1)ALACE.E ATTACKED.

Almonis (Amygdalus communis).-Penryn, Cal. (Budgett).

Peacir (Amygdalus persica).-Henshaw says:

In civilized districts the injury and even destruction of fruit trees [by the sapsucker] caused by the tearing off of large pieces of bark with the apparent design of reaching the tender inner bark or juices of the tree place it on the proscribed list of the farmers. In southern Vtah I visited peach orchards which had suffered severely from this ('ause. 
Hoy (1852) notes that sapsuckers visit "the orchards during September and October to feed upon the inner bark of the peach ... girdling the stems so effectually as not infrequently to kill the trees."

Hog Plum (Prunus injucunda).-Stone Mountain, Ga. (A. A. and A. M. 194).

Wild REd PluM (Prunus americana).-Florida (A. M. 199); Illinois (F. 26424).

Chickasaw Plum (Prunus angustifolia).-Missouri (A. M. 197).

WILD GOOSE PLUM (Prunus hortulana).Courtney, Mo. (A. M. 198).

Garden PLUM (Prunus domestica). - Illinois (F. 26423); Wisconsin, (Hoy, 1865).

Cultivated CHERR Y (probably Prunus avium).-The sapsucker is "very fond of cherry sap" (J.P.Moore, Easton, Pa., Oct. 9, 1887). It "visits the orchards during September and October to feed upon the inner bark of the ... cherry, girdling the stems so effectually as not infrequently to kill the trees" (Hoy, 1852).

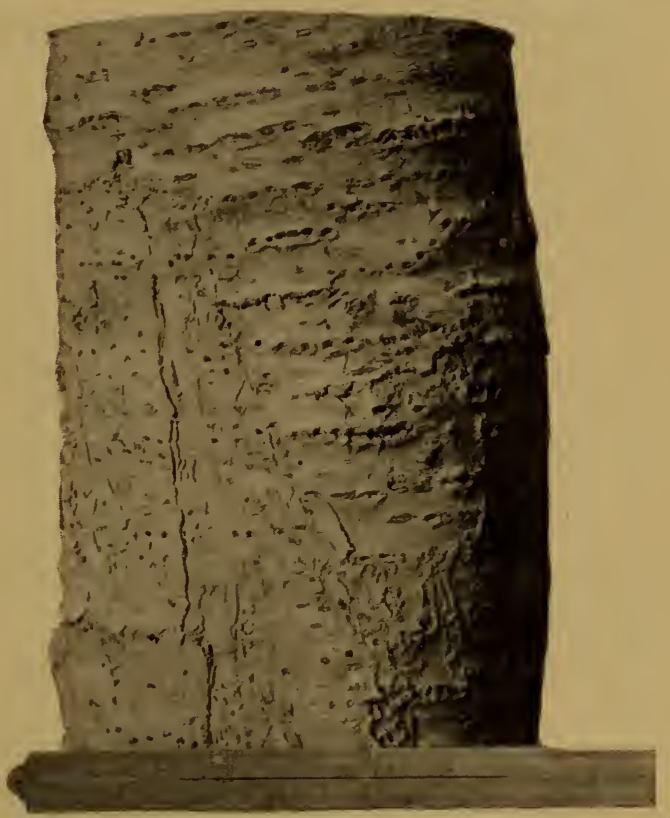

Fig. 8.-Sapsucker work on bitter cherry (Prunus emarginata).

BitTer CHeRry (Prunus emarginata).-Oregon (A. A. 191). (Fig. 8.)

Western CHOKe CHerry (Padus demissa).-California (A. M. 190).

Wild Black Cherry (Padus serotina).-Erie, Pa., Todd; Washington, D. C.; Randolph County, W. Va., (H. 6801a); Wisconsin, Hoy (1865); southern Arizona (A. A. and A. M. 188).

IsLAY (Laurocerasus ilicifolia).-California (A. A. and A. M̀. 185).

THE MIMOSA FAMILY (MIMOSACEE).

Fifteen species of this family become arborescent in the United States, only one of which, so far as known, is attacked by sapsuckers. Mesquite (Prosopis glandulosa).-Arizona (A. M. 174). 


\section{THE SENNA FAMILY (CASALPINACEN).}

'Two of the 12 native species of trees of this family are attacked by sapsuckers, and one of them at least is much disfigured. One West Indian species also is punctured by the sapsucker.

\section{LIST OF CESALPINACEA ATTACKED.}

WATER Locust (Gleditsia aquatica).-This tree is very commonly attacked by sapsuckers near Longbridge, La., and swollen girdles are produced similar to those figured for the honey locust.

Honey Locust (Gleditsia triacanthos).-Near Longbridge, La., nearly every tree is attacked by sapsuckers and protruding girdles are usually formed. One tree (fig. 5 and Pl. IV, fig. 3) was remarkably deformed, having shelflike girdles, some of which extend halfway around the tree and project 4 inches.

Logwood (Hæmatoxylon campechianum).-Bahama Islands, Moore. THE PEA FAMILY (FABACE.E).

Ten arborescent species of this family occur in the United States, of which two are known to be attacked by sapsuckers.

LIST OF FABACEE ATTACKED.

Locust (Robinia pseudacacia).-Randolph County, W. Va. (F. 73108).

Sonora Ironwood (Olneya tesota).-Arizona (A. M. 1.54).

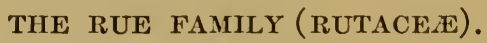

Only one of the nine native arborescent species is known to be molested by the yellow-bellied sapsucker.

Sitinwood (Xanthoxylum flavum).-Southern Florida (A. M. 150). THE MAHOGaNy FAMily (Meliacede).

The single native tree of this family, the valuable mahogany, is attacked by sapsuckers.

Manogany (Swietenia mahogani).-Dr. Hopkins obtained speciinens of veneer made of Cuban mahogany at Indianapolis, Ind., which prove that the sapsucker attacks this tree. A trunk collected on one of the Florida Keys has numerous pecks in the bark (A. M. 141).

THE SPURGE FAMILY (EUPHORBIACEE).

One of the four native arborescent species is attacked by sapsuckers.

Large Guinna plum (Drypetes diversifotia).-Florida Keys (A. A. 140). 


\section{THE SUMAC FAMILY (ANACARDIACEE).}

Yellow-bellied sapsuckers attack one of the nine native trees of this family.

SHoke TRee (Cotinus americanus).-Huntsville, Ala. (A. M. 136).

\section{THE HOLLY FAMILY (AQUIFOLIACEE).}

The genus Ilex includes all (11) arborescent species of this family occurring in the United States. Five of these species are known to be attacked by sapsuckers, and at least one of them (Mex cassine) to be killed. Nearly all the hollies are planted for ornament. The sapsucker pecking disfigures the smooth gray or white bark and sometimes results in the death of the trees.

LIST OF AQUIFOLIACEA ATTACKED.

Holly (Ilex decidua).--Red River Valley, Ark., Hough.

Holly (Ilex montana).-Allegheny Mountains, N. C., Hough.

Holly (Ilex cassine).-Cottonport and Longbridge, La.

Youpon (Ilex vomitoria).-Church Island, N. C.

Holly (Ilex opaca).-Matteson, Miss. (F.); Fannin County, Ga., November 29, 1909 (F.); Tennessee (A. M. 129); Abbeville, La.

\section{THE MAPLES (ACERACEA).}

The single genus of this family in the United States consists of 21 species, 9 of which are attacked by sapsuckers, 2 sometimes being killed. Sapsucker work is recorded for 1 introduced species. Evidently in some localities maples are great favorites with the sapsuckers, and many valuable ornamental trees are killed.

LIST OF ACERACEE ATTACKED.

STRIPEd MAPLE (Acer pennsylvanicum).-Western Maine, Wm. Brewster; Lewis County, N. Y., Hough.

SyCaMore MAPLE (Acer pseudoplatanus).-Smithsonian grounds, District of Columbia.

Silver Maple (Acer saccharinum).-Illinois (F. 26411 and 26492); Indiana, Butler (1897).

RED MAPLE (Acer rubrum).-Bolles describes sapsucker work on the red maple as follows:

The drills made by the woodpeckers began 18 feet from the ground and formed a girdle entirely around the trunk. The girdle contained over 800 punctures and was about 3 feet in height. In places the punctures or drills had run together causing the bark to gap and show dry wood within. . . The leaves on branches above the drills drooped; those below were in good condition.

Bendire says the bird "is partial to the . . red . . . maple," and "Hermit" states that "red maples ... were dead or dying" 
as a result of the pecking. Specimens from Essex County, N. Y. (A. M. 110), and Illinois (F. 26494) also show sapsucker work.

RED maple (Acer drummondi).-Cottonport, La.

Sugar Maple (Acer saccharum).-Bendire states that the sarsucker "is partial to the . . . sugar maple," and Purdy calls it one of the bird's preferred food trees. Butler says:

Choice maples are seriously damaged. . . . I have counted six of these birds at one time on a dozen sugar maples . . . and have seen the sap flow in a stream.

John Brady, of Batavia, Ill., testifies that the sapsucker hurts hard maple trees (Sept. 29, 1885), and M. S. Giles, of Waukegan, Ill., reports that sapsuckers-

destroy more shade trees-particularly hard maple and linden-than any one thing that I know of. I set out hard maples on my place over 32 years ago and I have only succeeded in saving them by persistently killing the sapsuckers for the past 6 or 7 years-for it was only as far back as that I woke to the damage that those birds were doing to the trees. Twenty years ago this place was noted for the number of hard maple shade trees it had; to-day I can show you in my own immediate neighborhood dozens of trees that are destroyed, or partially so, from the work of the "sapsucker" [May 2, 1909].

Specimens from Morgantown, W. Va. (H.); Louisville, Ky., and Illinois, and Iron County, Mo. (F. 26493 and 72158), also show sapsucker work.

BLACK MAPLe (Acer nigrum).-Illinois (F. 26410).

White-BaRked maple (Acer leucoderme).-Boulden, Ga. (A. M. 113).

Mountain MaPLe (Acer grandidentatum).-Garfield County, Utah (A. M. 112).

Box Elder (Acer negundo).-Butler County, Mo. (F. 72128); Fairfax County, Va.; Longbridge, La.

THE BUCKEYE FAMILY (ESCULACEE).

But one of the six native arborescent species is known to be molested by sapsuckers and that but slightly.

Оноо вUCKeYe (Esculus glabra).-Indianapolis, Ind. (H. 2423a).

THE BLCKTHORN FAMILY (RHAMNACEE).

Three of the 12 arborescent species of the United States are known to be attacked by sapsuckers. None are known to be injured severely, though the Indian cherry and the California lilac are undoubtedly disfigured.

LIST OF RHAMNACEN ATTACKED.

Cascara Sagrada (Rhamnus purshiana).-Seattle, Wash. (H. $174 b)$.

INDAN CHERrY (Rhamnus caroliniana).-Florida (A. M. 94).

Califoria lilac (C'eanothus thyrsiflorus).-California (A. M. 91). 


\section{THE BASSWOOD FAMILY (TILIACE.E).}

Four of the eight native trees of this family are attacked by sapsuckers and two introduced species. Swollen girdles are a characteristic result, sometimes greatly disfiguring these valuable ornamental trees. One species (Tilia americana) is known to be killed (see p. 46).

LIST OF THLIACE.E ATTACKED.

BAsswood (Tilia americana).-Randolph County, W. Va.(H.6801); Waukegan, Ill., May 2, 1909, M. S. Giles; Wisconsin, Hoy (1865); Illinois (F. 26405 and 26490); Allenton, Mo. (A. A. and A. M. 88); Butler County, Mo. (F. 731SS); Department of Agriculture grounds, District of Columbia; Plummers Island, Md.; Rockfish Valley, Va.

B.sswood (Tilia heterophylla).-Tennessee (A. A. and A. M. 87).

BAsswood (Tilia michauxii).-West Virginia (F. 74773).

Basswood (Titia pubescens).-Abberille, La.; Florida (A. M. S6).

Lindex (Titia europea).-Department of Agriculture grounds, District of Columbia.

Silky LINDEN (Titia tomentosa).-Department of Agriculture grounds, District of Columbia.

\section{THE FREMONTIA FAMILY (CHEIRANTHODENDRACEE).}

The single native representative of this family is attacked by sapsuckers.

Fremoxtia (Fremontodendron californicum).-San Jacinto Mountains, Cal. (A. A. and A. M. 85).

\section{THE TAMARISK FAMILY (TAMARICACE.E.)}

The single introduced species is attacked by sapsuckers.

TAMaRIsK (Tamarix gallica).-Belle Isle, La.

\section{THE OLEASTER FAMILY (EL.EAGNACE.E).}

One introduced species of this family is known to be attacked by sapsuckers.

Silver oleaster (Elæagnus umbellata).-Department of Agriculture grounds, District of Columbia.

\section{THE WHITE MANGROVE FAMILY (COMBRETACE王).}

All the native species, three in number, are attacked by sapsuckers. LIST OF COMBRETACEN ATTACKED.

Buttonwood (Conocarpus erecta).-Florida Keys (A. A. and A. M. 70$)$.

Black olive tree (Bucida buceras).-Elliotts Key, Fla. (A. A. and A. М. 69 ). 
White Maxgrove (Laguncularia racemosa).-Florida Keys (A. M. 68).

\section{THE MYRTLE FAMILY (MYRTACEA).}

One of the seven native arborescent species is known to be attacked. Spanish stopper (Eugenia buxifotia).-Key West, Fla. (A. M. 76).

THE DOGWOOD FAMILY (CORNACEA).

Six of the 10 native arborescent species are attacked by sapsuckers. None are known to be seriously injured.

LIST OF CORNACEE ATTACKED.

Sour gum (Nyssa sylvatica).-Dismal Swamp, Va., H. S. Barber.

Tupelo gum (Nyssa uniflora).-Illinois (F. 26433).

Ogeche plum (Nyssa ogeche).-Georgia (A. M. 66).

Connel (Cornus asperifolia drummondi).-Columbia, Tex. (A. MI. 62).

Flowering dogwood (Cynoxylon floridum).-Illinois (F. 26429); Cottonport, La.

Western dogwood (Cynoxylon nuttalli).-O-Oregon (A. M. 63).

$$
\text { THE IIEATH FAMILY (ERICACEX). }
$$

Two of the 13 arborescent species of the United States are attacked, one of which is severely injured.

Sourwood (Oxydendrum arboreum).-(A. A. and A. M. 55.)

Madroña (Arbutus menziesii).-A specimen collected by Dr. Hopkins at Grant Pass, Oreo., April 25, 1899, shows large continuous horizontal areas denuded of bark. After several years' growth the wood at the bottom of these wounds is still left exposed.

\section{THE HUCKLEBERRY FAMILY (VACCINIACEA).}

The single arborescent species of this family is attacked and patches of its bark are killed.

Tree huCKLeberry (Batodendron arboreum).-At Cottonport, Longbridge, and Abbeville, La., this species is abundantly punctured by sapsuckers. Most of the trees have girdles of pecks and the bark is killed in spots. The healing is slow and difficult, leaving patches of dead wood exposed and the exterior of the tree considerably distorted.

\section{THE SAPODLLA FAMLY (SAPOTACEA).}

Two of the 11 native trees of this family are attacked by sapsuckers.

Socthern buckthorn (Bumelia lycioides)._Florida (A. A. and A. M. 45). 
Arizona buckthorn (Bumelia rigida).-Western Texas or Arizona (A. A. 47 ).

THE EBONY FAMILY (EBENACE.E).

One of the two native trees is attacked by sapsuckers.

Persmarox (Diospyros virginiana).-Illinois (F. 26437); Cottonport, La.

THE STORAX FAMILY (STYRACACEE).

One of the two native arborescent species is attacked.

Silverbell tree (Halesia carolina).-Fannin County, Ga., December 6, 1909 (F.).

\section{THE OLIVE FAMILY (OLEACEA).}

Seren of the 21 native ash trees are attacked by sapsuckers, one being seriously injured. Three other genera, each with one arborescent species, complete the list of trees of the United States belonging to the olive family. One of these, the devilwood of Florida, and one introduced tree are sometimes punctured.

LIST OF OLEACEæ ATTACKED.

BLACK ASH (Fraxinus nigra).-Cranesville, W. Va. (H.).

AsH (Fraxinus oregona).--Oregon (A. A. 23).

Blue Ash (Fraxinus quadrangulata).-Iron County, Mo. (F. 7238s).

Water ASH (Fraxinus caroliniana).-J. M. Thompson.

Greex ash (Fraxinus pennsylianica var. lanceolata).-Georgia, West Virginia (F. 72372); Venice, La.

Pumpkix ash (Fraxinus profunda).-Butler County, Mo., June 2, 1908 (F.).

WhITE ASH (Fraxinus americana).-Bendire remarks that the sapsucker is partial to the white ash, and Bolles notes that it is "drilled for successive years" by sapsuckers and says "the forest trees attacked by them generally die." White ash trees near Cottonport, La., bore as many punctures as the bark would, hold. Sapsucker work was abundant on white ashes at Abbeville, La., and specimens showing sapsucker injury hare been examined from Illinois (F. 26439); Butler County, Mo. (F. 72438); Evansville, Ind., July 9, 1904 (H.); and Marion, Ind.

Devilwood (Osmanthus americana).-Florida (A. A. and A. M. 21).

Privet (Ligustrum sp.).-Newport, Ark. (J. W. and J. M. Stayton, May 27, 1911).

$99068^{\circ}-$ Bull. $39-11-4$ 
TIE FHRETIA FAMHY ( HHRETIACEA).

One of the five arborescent species of the United States is punctured by sapsuckers.

Nockaway (Fhretia elliptica).-Texas (A. M. 17).

\section{THE TRUMPET CREEPER FAMHYY (BIGNONACEA).}

'Three of the five native arboreseent species are attacked by sapsuckers.

LIST OF BIGNONIACE.E ATTACKED.

(Catalpa catalpa).-Smithsonian grounds, District of Columbia.

(Catalpa speciosa).-Allenton, Mo. (A. A. and A. M. 12); Illinois (F. 26441).

Desert Willow (Chilopsis linearis).-Arizona (A. M. 14).

THE MADDER FAMILY (RUBIACEN).

One of the seven native trees is attacked.

Buttoniush (Cephalanthus occidentalis) (A. A.).

THE HONEYSUCKLE FAMILY (CAPRIFOLACE.E).

Each of two genera of this family has five arborescent species in the United States. Of one, the elders, one species is known to be attacked and of the other, the black haws, three species. So far as known, none are seriously injured.

LIST OF CAPRIFOLIACEE ATTACKED.

Blue-berried elder (Sambucus glauca).-Oregon (A. M. 4). BLACK HAW (Viburnum lentago).-Missouri (A. A. and A. M. 3).

BLACK HAW (Viburnum prunifolium). -Georgia (A. A. and A. M. 1); Illinois (F. 26435).

BLACK HAW (I'iburnum rufidulum),-Rome, Ga. (A. A. 2).

TREES ATTACKED BY TIE RED-BREASTEI) SAPSUCKER.

$$
\text { (Sphyrapicus ruber.) }
$$

THE POPLARS ANI WHLLOWS (SALICACE.E).

Black cotTonwoon (Populus trichocarpa).-Bendire.

Cottoxwoon (I'opulus fremonti).-C. S. Thompson.

Weepras Whaow (Salix babylonica).- "I have noticed no other trees [besides apple and pear] damaged except perhaps the wecping willow." (Ernest Atams, Clipper Gap, Cal., Apr. 30, 1909).

Whisow (Salix cordata).-Vernon Bailey noted young Sphyrapicus ruber regaling themselves on willow sap at Donner Lake, Cal., July 
25, 1900, and found many branches pecked on a number of willows. Mrs. Bailey (see bibliography), referring to the same instance, describes "lengthwise strips of bark . . . cut off, learing fiddlestrings between." (See Pl. V, fig. 4.) ·

Willow (species not given).-A specimen of willow collected by Dr. A. K. Fisher at Tillamook, Oreg., shows alniost all the bark remored from a fair-sized sapling.

THE WALNUTS (JUGLANDACE.E).

Exglish WaLvut (Juglans regia).-The English walnut is very seriously injured (Ellwood Cooper, Santa Barbara, Cal., Jan. 22, 1909).

\section{THE BIRCHES (BETLLACE.E).}

Birch (species unknown).-Prof. F. E. L. Beal reports a whitebarked birch so seriously injured at Salem, Oreg., that it appeared to be dying.

THE OAKS (FAGACE.E).

CALIFOrNia BLACK OAK (Quercus californica).-All through the oak forests of the McCloud River country the black oaks were badly pecked (T. O. Emerson, Mar. 14, 1909).

Califoria live OAK (Quercus agrifolia).-C. S. Thompson.

THE BARBERRIES (BERBERIDACE.E).

Barberry (Berberis sp.).-C. S. Thompson.

THE SYCAMORES (PLATANACEE).

Californla sycamore (Platanus racemosa).-C. S. Thompson.

THE APPLE FAMily (MaLACE.E).

Mocytain ash (Sorbus sitchensis)._- "A species of mountain ash, on which none of the shoots were orer 3 inches through, had been riddled all orer by the birds" (Bendire).

Mouxtain asir (Sorbus sp.).-Prof. F. E. L. Beal reports an arborescent mountain ash so seriously injured at Salem, Oreg., that it appeared to be dying.

Pear (Pyrus communis).-The pear tree is attacked by the redbreasted sapsucker (IT. O. Emerson, Haywards, Cal., Mar. 14, 1909). "A pear tree 50 or more years old stands within 20 feet of our house and the trunk and lower branches are covered with symmetrically arranged pits" (Ernest Adams, Clipper Gap, Cal., Apr. 30, 1909). At Blaine, Wash., "the sapsuckers do immense damage, especially to the pear trees" (Dawson and Bowles). 
Aprte (Malus malus).- "Some apple trees [attacked by this species] died back at the top and did not thrive, so that I cut them down as useless" (Ellwood Cooper, Santa Barbara, Cal., Feb. 8, $1909)$.

Along in February and March this species does a good deal of tapping the apple trees, more particularly in old orchards isolated in outlying canyons and mountain flats. In one old apple orchard in Culls Canyon [near Haywards, Cal.] certain varieties of apple trees are badly girdled, as the bellflower, winter pearmain, and Baldwin. This I have noticed all through the Santa Cruz Mountains, where a good many apple orchards lav.

September 10, 1908, while on the McCloud River near Baird, Shasta County, I was in a small orchard patch of a dozen trees, situated in a deep ravine of the mountains, where no other orcharls were in miles; these trees were the worst affected of any I ever saw by the $S$.ruber work. From within a foot of the ground up, all the main branches were literally cut up with their sap holes. It could plainly be seen where the trees harl rapidly healed or grown up again and left the bark all pitted. No evil effert was noted as to small fruit, for I never saw finer sized nor colored apples in the coast counties. In a 10-mile drive from there to the railroad I observed wherever there grew an apple tree it was netted with ruber's sap holes. [W. O. Ėmerson, Haywards, Cal., Mar. 14, 1909.]

All the old [20 to 50 years] pear and apple trees are badly scarred up from the ravages of this bird. . . . I have removed numbers of the old apple trees which were affected. [Ernest Adams, Clipper Gap, Cal., Apr. 30, 1909.]

\section{THE PLUMS AND CHERRIES (AMYGDALACEE).}

PEACH (Prunus persica).-Mr. Carberry stated that if he did not keep these birds in check they would kill every fruit tree he owned. At least a dozen peach trees were scarred from top to bottom with small borings of this bird (J. II. Gaut, Burney, Cal., Aug., 1905).

Арricot (Prunus armeniaca)._- "It taps fruit trees, especially prune and apricot. . . . Trees are frequently killed by ... punctures. ... The evil ... is wrought in summer when the dry season has enfecbled the tree" (Cook).

Puum (Prunus domestica).- The plum is attacked by the redbreasted sapsucker (W. O. Emerson, Haywards, Cal., Mar. 14, 1909). See also quotation under Apricot, just above.

THE RUE FAMILY (RUTACEA).

Orange (Citrus aurantium).-- "Some complaint has been made from Riverside and Los Angeles Counties of this species cutting the orange trees badly during the winter months" (W. O. Emerson, Mar. 14, 1909). Orange trees are very seriousiy injured (Ellwood Cooper, Santa Barbara, ('al., Jan. 22, 1909).

TIE SUMAC FAMHY (ANACARDIACEE).

Pepper tree (Schimus molle).-The red-breasted sapsucker is "oftenest noticed, even along the noisy city streets, in the pepper trees, the sap of which this bird seems to particularly like" (Grinnell, 189S). 
THE MYRTLE FAMILY (MYRTACEÆ).

Blue GuM (Eucalyptus globulus).-This species is injured by the red-breasted sapsucker (Ellwood Cooper, Santa Barbara, Cal., Jan. $22,1909)$. "A number [of sapsuckers] have taken a fancy to a big blue gum tree in the yard, where on warm, sunny days they . . . go to peck holes and suck the rich sap that flows freely in the cold fall montlis" (Emerson).

\section{TREES ATTACKED BY THE IILLIAMSON SAPSUCKER.}

\section{(Sphyrapicus thyroideus.)}

Bull PINe (Pinus ponderosa).-_"Many grills of borings were seen in the bark of yellow pines and firs at Bluff Lake [Cal.] which I ascribed to this species" (Grinnell, 1908). A specimen from Pine Grove, Mont., collected by Joseph Brunner (I. 8516), is riddled with pecks, vertical strips of bark being cleanly removed.

Lodgepole PINE (Pinus murrayana).-Belding remarks that Williamson sapsuckers were "breeding in living tamaracks and covered with their resinous juices," which implies that the trees were tapped.

Pine (species not given).-Merrill notes that this sapsucker is "partial to young pines, with the soft inner bark of which, and fragments of insects, the stomachs of adults are usually filled."

White FIr (Abies concolor).- See quotation from Grinnell under Bull pine.

\section{SUMMARY OF INJURIES JEOPARDIZING THE VIGOR OR LIFE OF TREES.}

Condensing the information contained in the foregoing lists, we find that the yellow-bellied sapsucker attacks no fewer than 246 species of native trees and 6 vines, besides 31 kinds of introduced trees. Twenty-nine of these trees and 1 vine are known to be sometimes killed and 28 others are much disfigured or seriously reduced in vitality.

The red-breasted sapsucker, a bird much less observed, is known to attack 20 species of trees and shrubs, to damage individuals of at least 11 of them, and sometimes to kill members of 8 species. Considering the smaller range of this sapsucker and our comparative unfamiliarity with its habits, there is little doubt that bird for bird it is fully as detrimental to trees as the more widespread yellow-bellied woodpecker.

The Williamson sapsucker is here recorded as attacking 3 species of the pine family.

Combining the statistics for the 3 species of sapsuckers, we find that they are known to attack 258 trees, shrubs, and vines of 45 native families. These families are represented by 603 arborescent 
species in the United States, of which 248 are known to be punctured by sapsuckers. Thirty-eight introduced speeies are attacked, which belong to 17 families, 3 of which have no native representatives. Sixty-three of the total number of trees and shrubs are seriously damaged by sapsuckers and 31 of them, besides 1 vine, are known to be killed. There are 31 families of plants having native arborescent species in this country, and 7 wholly introduced families, no member of which is known to be attacked by sapsuckers. However, these families average less than 2 species each, while the native families, including the 258 species attacked, contain an average of 14 species each, so that our negative results for the former group are probably due in great part merely to the small amount of material examined rather than to the sapsuckers' distaste for trees of these families.

Indeed it seems probable that practically all trees accessible to sapsuckers will sooner or later be attacked. The only widespread and numerous trees not yet known to be punctured are the mulberries, Osage orange, and figs (family Moracex), and the palms and yuccas belonging to the endogenous subclass of plants, in which the circulation of sap is peculiar, which are presumably unsuited to sapsuckers.

The evidence shows that the three species of sapsuckers have practically the same habits and consequent injurious effects upon trees. However, the Williamson sapsucker is not now known to harm trees of great value. Leaving this species out of consideration and speaking only of the red-breasted and yellow-bellied sapsuckers, the above detailed testimony abundantly confirms the conclusion drawn from the anatomical structure and stomach examination, namely, that sapsuckers habitually feed upon bast, cambium, and sap. It further shows that in securing their favorite food they of ten remove so much of the growing layer of trees that the vigor of the latter is impaired, sometimes to such a degree that death ensues.

However strong seems the indictment against the sapsuckers, it must not be imagined that every tree pecked by them is doomed. On the contrary, they frequently work on a tree year after year without noticeably diminishing its vitality. Near Washington the writer has noted large elms whose trunks have evidently been attacked by many generations of sapsuckers and are freely drilled every year, but which to all appearances are now in perfect health. W. $\Lambda$. Taylor, of the Division of Pomology in the Department of Agriculture, states that at his home in southwestern Michigan there are several apple trees, now over 70 years old, which are known to have been yearly drilled by sapsuckers without diminishing their vigor or productiveness. The western half of the Department of Agriculture grounds at Washington contains 232 trees, of which 56 have been attacked by sapsuckers. 
Only one of these gives external evidence of injury, an English walnut, one limb of which has been partly killed, and only a few are noticeably disfigured.

While there is no doubt that trees may be freely attacked by sapsuckers without their lires being endangered, it is equally true that many trees, including valuable orchard and ornamental specimens, are seriously injured or killed by these woodpeckers. The owners of such trees have every right to protect them and should be given legal authority to do so.

\section{BIBLIOGRAPHY.}

Allex, J. A. Sphyrapicus rarius, Yellow-bellied Woodpecker. Notes on birds observed in western Iowa, etc. Mem. Boston Soc. Nat. Hist., I [1866-1869], 495-499, 1869.

Bailey, Florexce Merrlay. Sphyrapicus ruber (Gmel.), Red-breasted Sapsucker. Handbook of Birds of the Western United States, pp. 211-212, 1902.

Beldixg, Lymax. Sphyrapicus thyroideus (Cass.), Williamson's Sapsucker. Land Birds of the Pacific District. Occasional Papers of the California Acad. of Sci., II, $6 \bar{\imath}-68,1890$.

Bexdire, Charles. Sphyrapicus ruber (Gmelin), Red-breasted Sapsucker; Sphyrapicus varius (Linn:eus), Yellow-bellied Sapsucker; Sphyrapicus varius nuchalis Baird, Red-naped Sapsucker. Life Histories of N. A. Birds, II, 82-96, 1895.

Bolles, Frank. Yellow-bellied Woodpeckers and their Uninvited Guests. Auk, VIII, 256-270, 1891.

BudgetT, F. [Woodpeckers causing gum on almond trees.] Pacific Rural Press, XLIX, 275, 1995.

Berroughs, Јонх: Signs and Seasons, p. 145, 1895.

Bctrer, A. W. Sphyrapicus varius (Linn.), Yellow-bellied Woodpecker. A Catalogue of the Birds of Indiana. Trans. Ind. Hort. Soc., pp. 5S-59, 1890.

Butrer, A. II. Sphyrapicus varius (Linn.), Yellow-bellied Sapsucker. Birds of Indiana. 22nd Ann. Rep. Ind. Dept. Geol. and Nat. Resources, pp. 834-\$37, [189i] 1898 .

Curford, E. A. The Sapsucker Again. Prairie Farmer, XXI, 260-261, 1860.

Соок, A. J. Food of Woodpeckers and Flycatchers. Auk, XIII, 85-86, 1896.

DAwsox, W. L., and Bowles, J. H. Northwest Sapsucker, Sphyrapicus ruber notkensis Suckow. The Birds of Washington, I, 435-437, 1909.

Elliott, Roвert. Concerning Woodpeckers. Forest and Stream, LVI, 85-86, 1901.

EMersox;, W. O. Red-breasted Sapsucker (Sphyrapicus ruber). Fall Notes from Haywards, California. Bull. Cooper Orn. Club, I, 2S, 1899.

[Garfield, C. W.] The Sapsucker Again. Eleventh Ann. Rep. Secy. State Hort. Soc. Mich., pp. 205-206, 1881.

GriNeml, Joseph. Sphyrapicus ruber (Gmel.). Red-breasted Sapsucker. The Birds of the Pacific Slope of Los Angeles County. Pasadena Academy of Science. Pub. II, 25, 1898.

Grivsell, JosePh. Sphyrapicus thyroideus (Cassin), Williamson Sapsucker; Sphyrapicus varius daggetti Grinnell, Sierra Sapsucker. Biota of the San Bernardino Mountains. Univ. Calif. Pub., Zool., Y, 63-65, 1908.

Hexshaw, H. W. Sphyrapicus varius (Linn.), var. nuchalis Bd., Red-naped Woodpecker. Geog. and Geol. Expl. and Surv. W. of 100th Meridian, V, 392-393, 1875.

"HERMIT." Intelligence of Wild Things. Forest and Stream, LIX, 264, 1902.

Hopkiss, A. D. Ornaments and Blemishes in Wood Caused by Insects and Birds. MS. read before the Biol. Soc. of Washington, March 25, 1905. 
Horsforn, B. Yellow-bellied Woodpecker. Forest and Stream, XX, 124, 1883.

Hovgir, R. B. Handbook of the Trees of the Northern States and Canada. Lowville,

N. Y., 1907. Several photographs of trees show sapsucker work.

Hoy, P. R. Dendrocopus varius, Linn. Yellow-bellied Woodpecker. Notes on the Ornithology of Wisconsin. Trans. Wis. State Agric. Soc., II, 356, 1852.

Hoy, P. R. The Sapsucker. Trans. Ill. State Hort. Soc., V, 730-735, [1861-1864] 1865.

Jones, Lynns. Sphyrapicus varius (Linn.). Yellow-bellied Sapsucker. The Birds

of Ohio. Ohio Acarl. Sri. Special Papers, No. 6, pp. 113-114, 1903.

Kennari, F. H. January Occurrence of the Sapsucker in Brookline, Mass. $\Lambda u^{6}$ XII, 301-302, 1895.

Merriam, C. IIArt. Sphyrapicus varius. Yellow-bellied Woolpecker. Remarks (in some of the Birds of Lewis County, northern New York. Bull. Nuttall Orn. (Club, IV, 1-6, 1879.

Merrill, J. (. Sphyrapicus thyroideus. Notes on the Birds of Fort Klamath, Oregon. Auk, V, 255, 1888.

Mooke, N. B. Observations on some Birds seen near Nassau, New Providence, in the Bahama Islands. Proc. Bost. Soc. Nat. Hist., XIX, 245, 1878.

Morris, C. II. Winter Notes on the Yellow-bellied Sapsucker (Sphyrapicus varius). Wilson Bull. XII, 56-57, 1905.

Purny, J. B. The Red-headed and other Woodpeckers in Michigan in winter. Auk, XVII, 174, 1900.

Thompson, Charles S. The Woodpeckers of the Upper Salinas Valley. Condor, II, $52-55,1900$.

Thompson, J. M. The Sapsucker. Appleton's Journal, VIII, 631, 1872.

Todd, W. E. Clyde. Sphyrapicus varius. The Birds of Erie and Presque Isle, Erie County, Pennsylvania. Annals Carnegie Museum, II, 559, 1904.

Warken, B. H. Sphyrapicus varius. Yellow-bellied Sapsucker. Report on the Birds of Pennsylvania. Ed. 2, pp. 168-170, 1890.

Ween, C. M., and Dearborn, Ned. The Yellow-bellied Woodpecker or true Sapsucker. Birds in their Relations to Man. Pp. 189-191, 1903.

Wrigut, M. O. Yellow-bellied Sapsucker: Sphyrapicus varius. Birderaft, pp. 198-199, 1897.

\section{EFFECTS OF SAPSUCKER WORK ON LUMBER AND FINISHED WOOD PRODUCTS.}

INTRODUCTION.

Those relations of sapsuckers to trees which are detrimental to man's interest are by no means confined to the external disfiguration, the weakening, or killing of trees. Indeed in the aggregate sapsuckers inflict much greater financial loss by rendering defective the wood of the far larger number of trees which they work upon moderately but do not kill. Blemishes, reducing the value, appear in the lumber from such trees and in the various articles into which it is manufactured.

These defects consist of distortion of the grain, formation of knotty growths and cavities in the wood, extensive staining, fat strealss, resin deposits, and other blemishes. All of them result from injuries to the cambium, their variety being due to differences in the healing. Besides blemishes, ornamental effects are sometimes 
produced during the healing of sapsucker wounds, such as small sound stains, curly grain, and a form of bird's-eye.

The earliest communication we have on this point is from Charles Eshorn, jr., of Medora, Ind. On May 27, 1892, he wrote to the Biological Survey as follows:

[The sapsucker] ruins a great deal of valuable forest timber, namely, oak and hickory, by pecking holes. . . . As the tree grows these places decay, which renders the timber unfit for spokes, staves, etc. These birds are not very numerous, but it seems that each individual can do a great deal of mischief, and should the country be overrun with them they would be a great drawback to the timber business.

The relation of sapsuckers to lumber was first studied by Dr. A. D. Hopkins while he was connected with the West Virginia Agricultural Experiment Station. He discovered that curly and bird's-eye wood are often caused by injuries to living trees by woodpeckers. Dr. Hopkins read a paper on the subject before section $F$ of the American Association for the Advancement of Science, ${ }^{1}$ and another before the American Forestry Association in August, 1894, and he spoke on the same subject at a meeting of the Biological Society of Washington March 25, 1902. Dr. Hopkins has generously turned over to the Biological Survey the manuscript and photographs illustrating the latter communication, in addition to lis large collection of wood samples showing woodpecker work. This collection, augmented by material gathered by the writer in the field or examined in various museums, forms the basis of this section of the bulletin.

In his address on "Ornaments and blemishes in wood caused by insects and birds," ${ }_{2}$ Dr. Hopkins says:

Blemishes or defects appear in lumber and wood finish as discolored spots, checks, dark stains, resin deposits, pinholes, wormholes, etc., and in the trees as scars, decayed spots, and hollow trunks.

Ornamental conditions appear in the lumber and inside finish and furniture as so-called bird's-eye, curly, burl, and wavy or satined effects and on the surface of the wood beneath the bark as artistic and curious carved and embossed work.

Twenty or thirty years ago, when the choicest material could be selected from an abundant and cheap supply, blemishes were rarely seen, even in the cheaper finished products. Within recent years, however, the supply of choice lumber free from defects is becoming so scarce that none but the most expensive finished articles are entirely free from them. Indeed, it would be difficult to find a recently constructed public huilding or private residence which does not show in the natural wood finish one to many blemishes, the result of various causes. Most of them which are not natural conditions in the wood are caused primarily by insects, birds, mammals, and various other agencies which produce wounds in the cambium of the living tree.

\footnotetext{
1 Hopkins, A. D., Some interesting conditions in wood resulting from the attack of insects and woodpeckers. Proc. Am. Assn. Adv. Sci. 1894, p. 252 [abstract]. Excerpts from this paper were published by Dr. Hopkins under the title "The Relation of Insects and Birds to Present Forest Conditions, "in Garden and Forest, VII, 348 and 373,1894 . Its subject matter was brought before the Biological Society of Washington by Prof. C. V. Riley, Dec. 15, 19.7, in a paper entitled "Some Interesting Results of Injuries to Trees;" and a review by H. C. Hovey appeared in the Scientific American, LXXI, 163, 1894.

2 Meeting of Biol. Soc. Wash., Mar. 25, 1905.
} 
The condition in wood of rarious kinds resulting from the everywhere common work of the clats of woudpeckers known as sapsuckers in the lark of forest and cultivated trees has heen the sulject of special interest to me for many years, and my work on forest insects has naturally offered a good opportunity for observations and the collecting of specimens. The material collected represents some 40 species of forest trees of many genera and families and from widely differing sections of the country.

It appears that the olject of the sapsucker working in the hark of living trees $\mathrm{i}$ s to secure both liquid and solid food from the sap), cambium, and bast, and not for the purpose of collecting insects, or at least not primarily for that purpose. The punctures in the bark vary in size, form, and arrangement according to the species of tree and the character of the food furnished. In the pine, spruce, heinlock, juniper, and probably in all conifers, the desirable substance is furnished by the living hast tissue and cambium, while the wood yields resin instead of sap; therefore the birds have no occasion to puncture the outer wood ring and very rarely do so, whereas in maple, walnut, hickory, and such trees as furnish at certain times of the year a profuse flow of saccharine sap from the sapwood the outer ring of wood is generally punctured. In the former the wounds are usually broad, of ten connected, and arranged in longitudinal rows, ${ }^{1}$ while in the latter they are narrow, funnel-shaped, rarely joining, and arranged in transverse rows. The method of healing of these wounds is quite variable, being influenced not only by the character of the wound but by the species or class of trees in which they occur. The resulting defective or ornamental conditions and subsequent annual layers of wood also vary in character and economic importance with different kinds of trees and commercial products.

The way in which sapsucker pecks are healed and the characteristic blemishes and ornamental effects produced may best be understood by the detailed consideration of these effects in a tree in which they are well marked. For this purpose the sugar or hard maple ${ }^{2}$ (Acer saccharum) is selected, a favorite tree of the sapsuckers and one often seriously injured by them. The punctures sometimes penetrate only to the sapwood, but generally they pierce one or more annual rings. Whatever the character of the original wound, more or less staining, varying from light yellow to dark brown in color, takes place in its vicinity and sometimes extends several inches up and down the grain. The greater the injury to the sapwood the more extensive is the stain. When the sapsucker's drill extends only to the sapwood, distortion of the wood healing the wound is usually at a minimum. It can make excess growth only by bulging out into the hole in the bark. Upon the extent of this swelling depends the amount of abnormality in succeeding annual rings.

Figure $9 \mathrm{~A}$ of the excellent series furnished by Dr. Hopkins illustrates this type of healing. Here the excess growth was small and would probably have been smoothly covered by the next annual layer, though a second stain would have been produced owing to

I'robably the contour of the bark has much to do with the arrangement of punctures. Conifers often have very thlck bark hut with longitulinal cracks where the wood can he more quickly reached. Ver tlcul serles of pecks orcur on deciduous trees also, especially upon those having long riclges or strips of thick bark wlth furrows hetween

${ }^{2}$ The sperimens of hard maple here flisenssel were collected at Morgantown, W. Va. (Hopkins). and in IUinols ( 1 26.49:3) 
exposure of the cambium. Figure $9 \mathrm{~B}$ further shows the results of failure to close the hole in the bark and to cover the original wound, thus leaving the sapwood exposed and liable to increased staining. A cone of cambium and bast has formed over the bottom of the peck, which will persist permanently as a rounded protuberance and over which all succeeding wood lasers will be molded. A condition similar to this in a specimen haring one larer of sapwood excavated is shown in the next figure (fig. 9C). The wound is not closed, the wood is left exposed, and if the healing has been completed for the season, an inwardly projecting cone will be left as before which will affect the form of future annual rings. Figure $9 \mathrm{D}$ shows a specimen in which two rings of sapwood have been punctured and the next year's growth has been vigorous, filling the original wound and pushing out into the hole in the bark. Succeeding wood layers

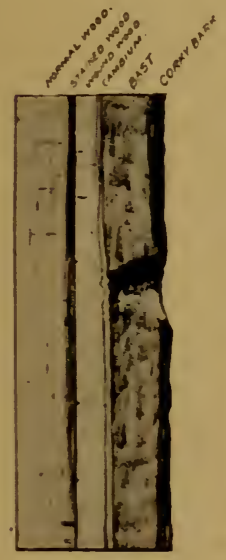

A

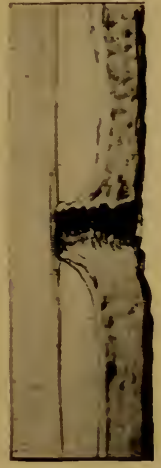

$B$

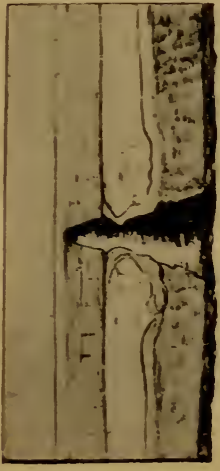

C

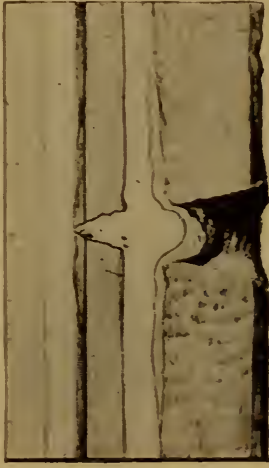

$D$

FIG. 9.-Effects of sapsucker work on wood of sugar maple (Acer saccharum). (From Hopkins.)

would be bent outward over the protuberance which partly fills the wound. The conditions in wood which has made sereral years' growth since the original injuries is shown in figures $10 \mathrm{~A}$ and $10 \mathrm{~B}$. Both illustrate specimens in which the sapwood was punctured and extensive staining has resulted. In one case vigorous growth followed the injury and the healing has taken place as in figure $9 \mathrm{D}$, with the result that the annual layers of wood are bent outward over the wound. The other specimen gires eridence of weaker growth, only partly filling the original hole and not pushing out into the bark opening. Hence the more vigorous new bast pushed into the vacancy, forming a protuberance on the inner side of the bark, between which and the depression over the original wound the next layer was formed. In consequence the latter also was bent inward and so was every succeeding layer. 
To recapitulate, figures $9 \Lambda$ to $9 \mathrm{D}$ show wounds 1 year old healed in various ways. Least progress is shown in $B$ and $C$, in both of which the wound has failed to close. A conical projection is formed on the inside of the bark, which makes a deep depression in following wood layers, as is illustrated by figure $10 \AA$. Figures $\mathrm{A}$ and D show wounds promptly closed by more vigorous growth. In figure $\Lambda$, as the peck extended only to the sapwood, the succeeding annual layer is smooth internally and because of small growth only slightly distorted externally under the bark hole. In figure D one ring of sapwood is entirely and another partly pierced. The new growth has been so thrifty that the original peck has been filled and a plug also pushed out into the bark opening. Methods of healing as illustrated by figures $9 \mathrm{~A}, 9 \mathrm{D}$, and $10 \mathrm{~B}$ produce a pit on the

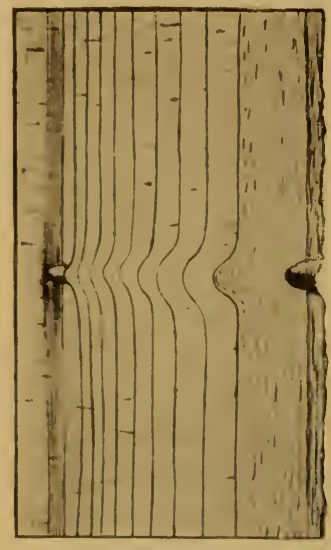

A

FIG. 10.-Eifects of sapsucker work on wood of sugar maple (Acer saccharum). (From Hopkins.) inner side of the bark which causes corresponding elevations in succeeding layers of wood. As a rule, then, if the growth following sapsucker wounds is vigorous, succeeding layers of wood will be bent outward over the wound; if weak, the grain will bend inward. In either case radial sections (fig. 10) of the wood reveal the curl in the grain and tangential sections cutting through the curls show a condition resembling natural bird's-eye (Pl. IX, fig. 6). As it can usually be recognized from the arrangement of the bird's-eyes in rows (see Pl. XII) corresponding to the well-known type of sapsucker work in the bark, it may well receive the name of sapsucker bird's-eye.

The question now arises, What is the effect of sapsucker work upon the commercial value of hard maple wood? The bird's-eve and curl, and even small stains if hard and sound, may be considered as ornamental and as enhancing the value of the wood. But extensive staining, a common accompaniment of sapsucker work in hard maple, is detrimental. Furthermore, the original pecks, if on the surface, appear as cavities surrounded by bleached and stained wood (Pl. IX, fig. 4), which must be planed off before the wood can be put to decorative use. The strength of the wood is not greatly affected except when pecks are numerous in a single annual layer, in which case this layer constitutes an easy splitting plane. 
The failure of the original wounds to close or the formation of loose, knotty, and gnarled tissue, together with excessive staining, are serious defects which greatly reduce the market value of the lumber, as may readily be seen from the following definition of the grades of maple lumber:

Firsts.-Firsts must be 8 inches or over wide, 10, 12, 14, and 16 feet long, and free from all defects. except in pieces 10 inches or over wide, which may have one sound standard defect.

Seconds.-Seconds must be 6 inches or over wide, 8 to 16 feet long; pieces 8 feet long must be clear.

No. 1 commons.-No. 1 commons must be 3 inches or over wide, 6 to 16 feet long; pieces 3 or 4 inches wide must have 1 face clear.-[Inspection rules, National Hardwood Lumber Association.]

It is evident that lumber sawn from a maple abundantly punctured by sapsuckers would not fare well at an inspection. Very few, if any, clear pieces of the sizes abore specified, the smallest of which is 3 inches wide by 6 feet long, could be obtained from such a tree. Hence most of the lumber would be classed as No. 2 common, the fourth market grade, which means a heary loss.

The effects of sapsucker work in other trees are more or less similar to those in hard maple, but vary according to the extent of injury and the habits of growth of the tree. For instance, the defects are usually much more pronounced in trees in whose bark holes remain open long, whether owing to slow growth or other reason. On the other hand, trees of rapid growth quickly heal and the blemishes are small and soon deeply buried. Wood with especially porous grain is extensively stained, while dense wood is less affected.

Defects due to sapsucker work are sufficiently similar in a general way, however, to be identifiable in any wood. On the end of logs, healed supsucker wounds or bird pecks, as they are commonly called, appear as larger or smaller stains with more or less open fissurcs or checks extending a short distance toward the bark. The general effect is that of $T$-shaped or triangular marks or cavities surrounded by more or less stain. Several usually occur along the same wood ring (see figs. 24, 29, 33, 37; Pl. VIII, fig. 2; Pl. X, fig. 3). The checks may be continuous, in which case they constitute a defect knowin as rind gall (see figs. 30 and 35). In longitudinal section, as in most boards and in quarter-sawn or sliced material, bird pecks usually appear as small knots (also often T-shaped-figs. 15, 16, and 23) around which is a greater or less amount of stained wood. They are easily distinguished from true knots, howerer, which are due to adventitious buds and embedded bases of twigs and limbs. The gnarly or curled growth caused by bird pecks is all on one side of a line of separation between annual rings (see figs. 15, 17, 22, and 23). In 
other words, the distortion of grain is confined to a half circle. An ordinary knot has no such definite relation to the wood layers, and is likely to be approximately circular in section. In rotary cut material and of course occasionally in ordinary lumber (longitudinal sections), bird pecks are cross sectioned, and generally show as transverse oblong holes, sometimes filled with loose wood, from which stains run up and down the grain (see figs. 11, 18, and 20). It is probable that the wounds made in trees by other woodpeckers sometimes heal so as to present the same appearance as sapsucker pecks; but these generally occur only as isolated blemishes, not in series, as sapsucker pecks nearly always do. Sapsucker pecks vary in economic bearing in different trees according to their abundance, the character of defects and ornaments produced, the uses to which the lumber is put, and its value.

WOODS IN WHICH BLEMISHES OR ORNAMENTAL EFFECTS ARE KNOWN TO RESULT FROM SAPSUCKER WORK. ${ }^{1}$

\section{THE YEW FAMILY (TAXACE E).}

Defects due to sapsucker pecking have been observed in two species of this family. In the stinking cedar they are unimportant. In the Florida yew, however, their nature and extent are such as to ruin both the appearance and the strength of the wood. They consist of small (one-fourth inch) black stains, accompanied by open knotty checks, gnarly grain, and long, open resinous seams, which in some cases constitute a complete cleavage between annual layers very similar to the defect known as cup shake.

\section{THE CONE-BEARING TREES (PINACEE).}

This family includes the most important timber trees of the United States. We find defects produced in the wood of 29 of the 90 native species. Ordinarily these defects vary from small to extensive brown or black, often transverse, stains to open checks up to an inch and a half in length, accompanied by fat streaks, resin deposit, and curled or gnarly grain in the wood layers overlying the healed punctures. Such defects have been observed in the following 12 species: White bark pine, lodgepole pine, long-leaf pine, scrub pine, red spruce, tideland spruce, castern hemlock, Douglas fir, red fir, and three species of

\footnotetext{
In this list the family summaries give general conclusions regarding defects. Full accounts are given of speries showing typical or severe injuries, and the treatment of each family closes with a list of all the syecies in which blemishes or ornuments have been observed.

Where no locility or muscum collection is cited, the specimens referred to are those given in the list of tres injurel or killed (1p).21-53). Where several specimens of a species are mentioned in that list, the particular specimens discussed lore are indicated by ritution of the locality or museum initials. The spereies recorlecl do not inclicate the total damage done to lumber by sapsuckers, as we have been able to exanine woorl specimens showing ilefeets in only 70 per cent of the species known to be attacked by sapsuckers, and that list is by no means complete.
} 
white firs. The injuries are sufficient to keep lumber containing them out of the better grades used for finishing purposes. This involves the loss of a large percentage of the selling price, and the damage may reach serious proportions, as trees of this family are sometimes rigorously attacked. While the ordinary defects in the wood are undoubtedly a source of weakness in small pieces, they are of no account in large beams and other heavy construction material, for which these woods are much used. The long-leaf pine and white fir described below illustrate defects of this character.

Sapsuckers render certain woods of this family valueless for even coarse construction. They remove large areas of bark, usually in narrow vertical strips, and the injuries are so extensive as to leave cleavage places in the wood. Defects of this character have been observed in bull pine, pitch pine, Engelmann spruce, and western hemlock.

Injuries less extensive, but important because of special uses of the lumber, are described below for red cedar and cypress. In Monterey cypress and desert juniper the small black checks and brown stains are sound or accompanied by so much curled grain and bird's-eye that they embellish the wood.

Sapsucker wounds afford favorable conditions for the entrance and growth of a fungus (Peridermium cerebrum) which produces large galls on pine trees. When abundant, these galls so distort the trees that they become useless for lumber. Ob-
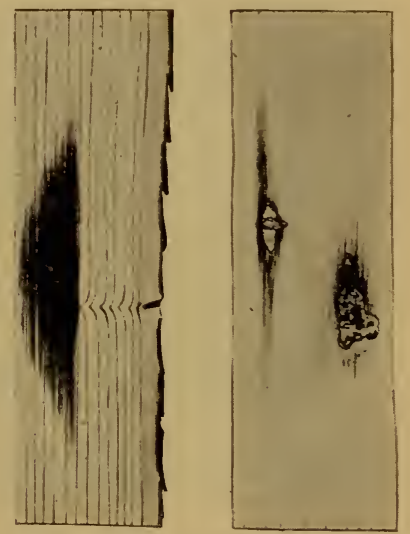

FiG. 11.-Effects of sapsucker work on wood of long-leaf pine (Pinus palustris). Radial and tangential sections. (From Hopkins.) servations upon scrub and short-leaf pine show that not infrequently the fungous attack begins in sapsucker wounds.

LONG-LEAF PINE (Pinus palustris).--Black stains with resin deposit are produced about sapsucker wounds in this wood, and lighter stains extend some distance along the grain. These shade off into fat streaks, which may permeate many layers of wood and reach far up and down the grair. Figure 11 shows the appearance of healed bird pecks in this pine. The illustration of the tangential section does not show as extensive staining as is sometimes present. The cavities there delineated are filled with resin. (Specimens from Baldwin, Fla.; Boardman, N. C.; and Buna, Tex.) A specimen from Florida (A. M. 485) shows a series of very extensive pitch streaks half an inch in thickness and 3 to 4 inches long in one direction from the wound. Blemishes in the long-leaf pine are serious enough to keep the lumber out of finishing grades. 
Winte run (Abies concolor). - The defects are one-fourth to 1 inch long, filled with resin drposit and giving rise to fat streaks extending a foot or more along the grain. Many layers of wood over the wound have curly grain. The blemishes are of no consequence for coarse structural work, but destroy the value of the wood for ornamental purposes (Oregon, 1. M. 444).

Westerx ImenLock (T'suga heterophylla).-A specimen of this wood collected at Detroit, Oreg. (II.), shows reddish to black resinous scars 1 to $3 \frac{1}{2}$ inches long, and the wood immediately orer the wound gnarled and distorted, and one or two annual rings impregnated with a black crystalline resin deposit. The smaller blemishes produced by sapsucker work are practically identical with those described by II. E. Burke as black check, which is caused "by an injury to the cambium

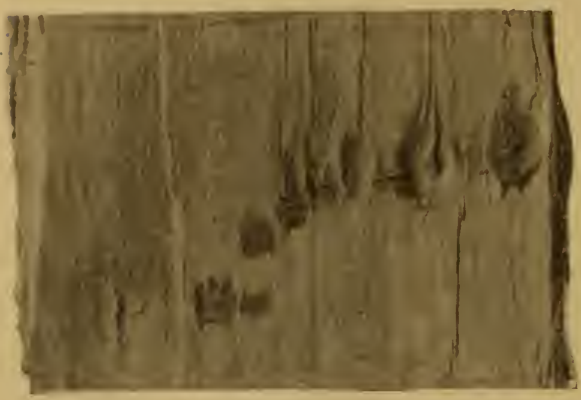

Fig. 12.-Effects of sapsucker work on wood of bald cypress (Taxodium distichum). Checks and stains. ... by the hemlock bark magrot, Cheilosia alastiensis." Mr. Burkesays: "Timber badly affected with this defect is nearly worthless for finishing, turning, stares, and woodenware, for which it would otherwise be excellent."1 But injuries by sapsuckers generally occur on a larger scale and consequently are more damaging. Specimens of western hemlock collected by Mr. Burke at Hoquiam, Wash. (H. 2167a), show the remoral by sapsuckers of long vertical strips of bark, exposing the sapwood (PI. VIII, fig. 3). 'This weat hers to a dark color and when healed over persists as a darkly stained area from 2 to 3 inches wide and up to several feet long with more or less resin deposit, making a thin brittle layer in the wood along the plane of which splitting easily occurs (PI. VIII, fig. 5). The defect is extreme, both as to weakness and unsightliness, and when abundant and scattered throughout the wood, as sapsucker blemishes usually are, must render the wood valueless for all structural purposes. Besides the direct injuries to western hemlock by sapsuckers, their pecks in the bark furnish entrance to bark magrots.

Bar.D CYpress (Taxodium distichum). - Specimens from Boardman, X. C. (H.), show dark stains produced by sapsucker wounds in cypress and distortion of the grain in several annual rings, some of which give a bird's-cye appearance in tangential section. Pieces of cypress from Cottonport, La., have numerous black stains (fig. 12) from one-fourth to $1 \frac{1}{3}$ inches in length and often noarly contiguous. In some cases the holes drilled by the sapsuckers have not healed readily and have left 


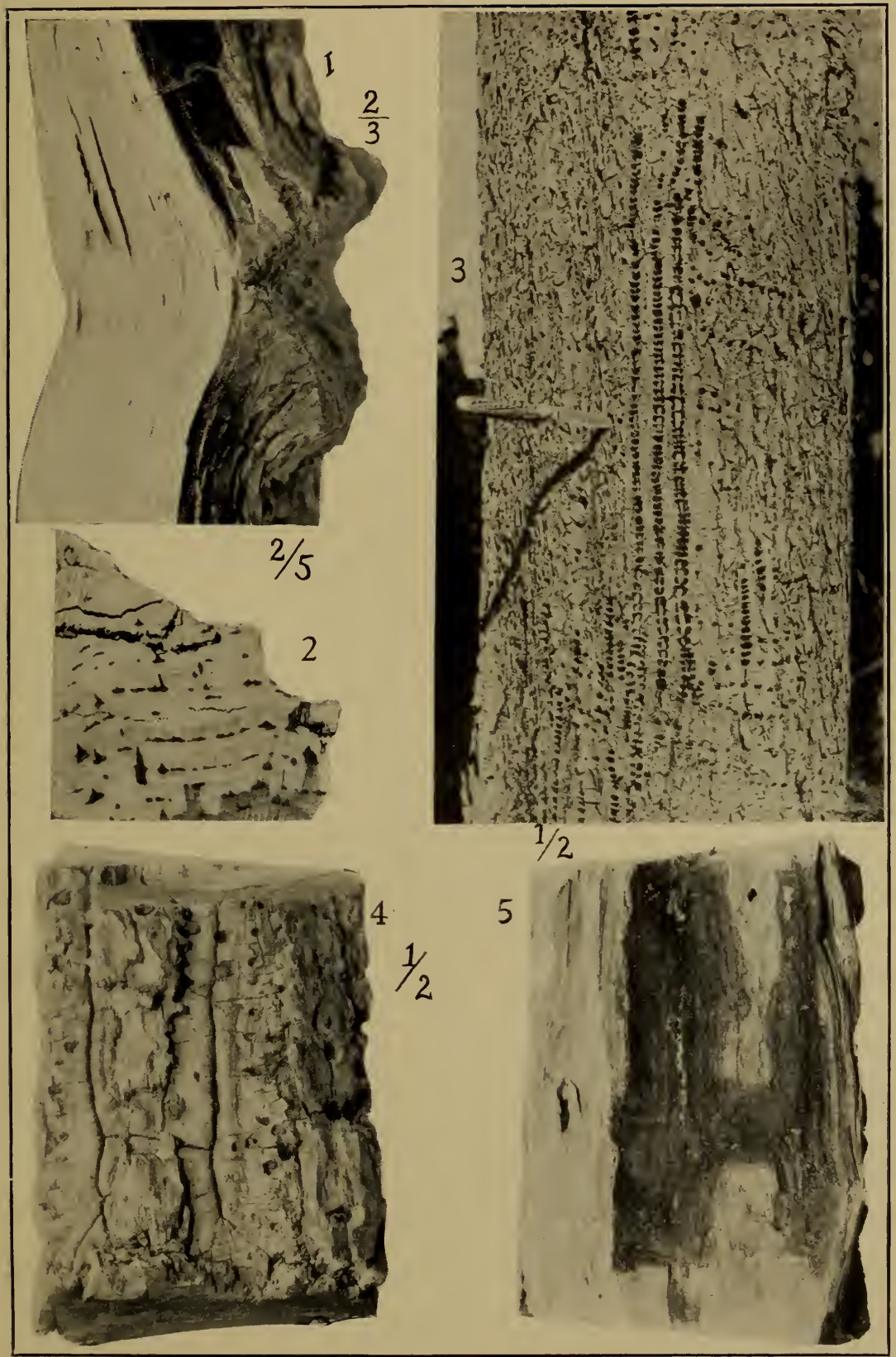

Work of Sapsucker on WHITE ELM AND Western Hemlock.

$[1$, Radial section through swollen girdle on white elm, showing strong curl of grain. 2, Cross section; checks and stains. 3, Long vertical series of punctures in western hemjock. By H. E. Burke. 4, Exterior view of healed-over wounds of similar nature. 5, Interior view; extensive stain.] 

open checks. Some of these form a narrow open knot an inch long. Distorted grain is very abundant and ranges from ornamental bird'seye to abundant bunches of gnarls (fig. 13), which ruin the appearance and workability of the wood.

At Cottonport, La., the writer had an opportunity to learn what proportion of the wood of cypresses abundantly punctured by sapsuckers is defective. Out of 189 palings split from one cypress, 29, or nearly 16 per cent, bore enough black stains to ruin the wood for any ornamental purpose. In a lot of 322 palings, 111 , or nearly 39 per cent, showed much gnarled grain accompanied by a few black spots. The gnarly wood and open knots are most objectionable ir. cypress, which is much used for purposes requiring easy working qualities and strength in slender pieces-for instance in greenhouse construction.

Northery red CEDAR (Juniperus virginiana).-Sometimes open fissures extend from checks toward the bark, surrounded by stain and gnarly wood. Even more objectionable are cases where the grain of the wood about the healed punctures is very wary and each

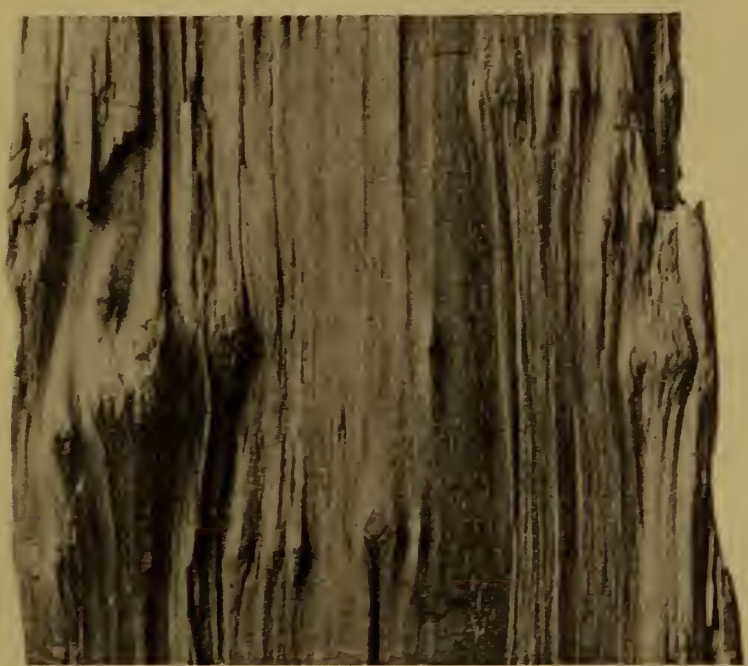

FIG. 13.-Effects of sapsucker work on wood of bald cjpress ( Taxodium distichum). Gnarly grain.

scar has one or more outwardly projecting tubercles (fig. 14, and Pl. XI, fig. 3), varying up to an inch in length, and requiring at least two complete annual rings of wood to bury them. These tubercles, together with the gnarled grain and extensive resin deposit, produce a hard, knotty, brittle layer of wood. The wounds have small carities and light but continuous stains. Wood thus disfigured is unsightly and unworkable. The greater part of the output of red cedar is used for pencil wood. for which the requirements are very exacting. A soft wood, eren and straight grained, free from defects, is essential. ${ }^{1}$ Trees of this species are very commonly worked on by sapsuckers, and often they are corered with rings of pecks. The writer found 19 out of 40 trees punctured on a small area on Plum- 
mers Island, Md. It is evident that considerable loss may be oceasioned by the work of sapsuckers on red cedar. (Specimens from Plummers Island, Md.; Kanawha Station, W. Va.

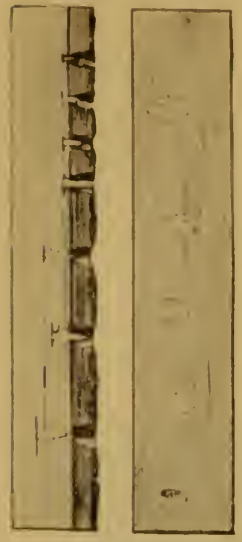

Fig. 14.-Erfects of sapsucker work on wood of red cedar ( $J$ uniperus virginiana). Radial and tangential sections. (From Hopkins.) (II.); Illinois (F. 264S7); and Florida (A. M. 417).) Species of Pinacee BLEmisned.-Whitebark pine, nut pine, bull pine (by Williamson sapsucker, H. S516), lodgepole pine, long-leaf pine, pitch pine (H.) (Pl. XI, fig. 2), scrub pine, red spruce (H.); Engelmann spruce, weeping spruce, tideland spruce, eastern hemlock (H.), western hemlock, Douglas fir, Abies concolor, A. grandis, A. amabilis, A. magnifica (fig. 15), A. nobilis, big tree, bald cypress, incense cedar, canoe cedar, Monterey cypress, Macnab cypress, white cedar (H.), desert juniper, western juniper, and northern red cedar.

THE POPLARS AND WILLOWS (SALICACEE).

The defects due to sapsucker work on poplar vary from small, slightly stained checks to large open knotty cavities, bordered or partly filled with decayed wood. Sometimes these checks cause the development of adventitious buds, thus making true knots. Over these. as well as over the normally healed pecks, are curls in the grain. which in some cases are duplicated through a great many annual layers (fig. 16). These ornament the wood, but it is doubtful if they counterbalance the disadvantage of the many $l a r g e$ checks. The latter unfit the wood of black cottonwood, tacmaliac, and ('arolina poplar

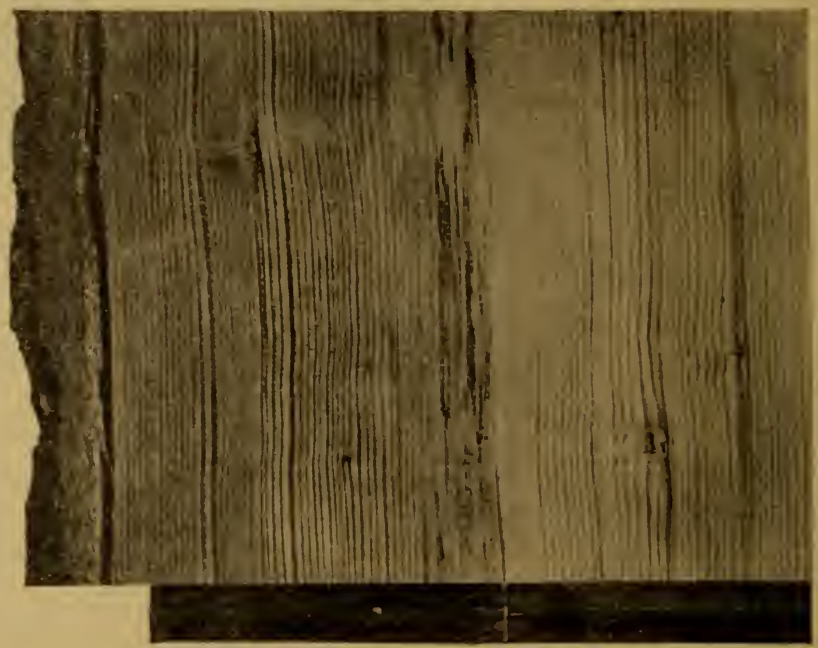

Fiti. 15. -Effects of sapsucker work on wood of red fir (Abics magnifica). Checks, stains, gnarled and curled grain.

for one of its principal uses - the manufacture of tubs, barrels, and woodenware. 
Sapsucker work in willows is difficult to identify, both because the pecks in the bark are quickly effaced and because the appearance of the defects in the wood is so often complicated by adventitious buds. The usual appearances in the wood are small light stains and nipplelike projections orer the healed wounds and consequent outward curling of the grain of many layers of wood (fig. 16). However, the checks and stains may be large and black (fig. 17 ), and extensive light stain may permeate the wood in all directions from the original wound. The checks are sometimes filled with softer, lighter-colored wood, and when adventitious buds develop they increase the distortion of the grain and sometimes form true knots. Willow wood is little used in the United States, but the distortion of the grain caused by sapsuckers by no means improves it for any purpose.

SPECIES OF SAlicaCEE BLEMISHED.Silver poplar (H.), swamp poplar, black cottonwood (fig. 16), balm of Gilead, tacmahac (A. A.), Carolina poplar (A. M.)

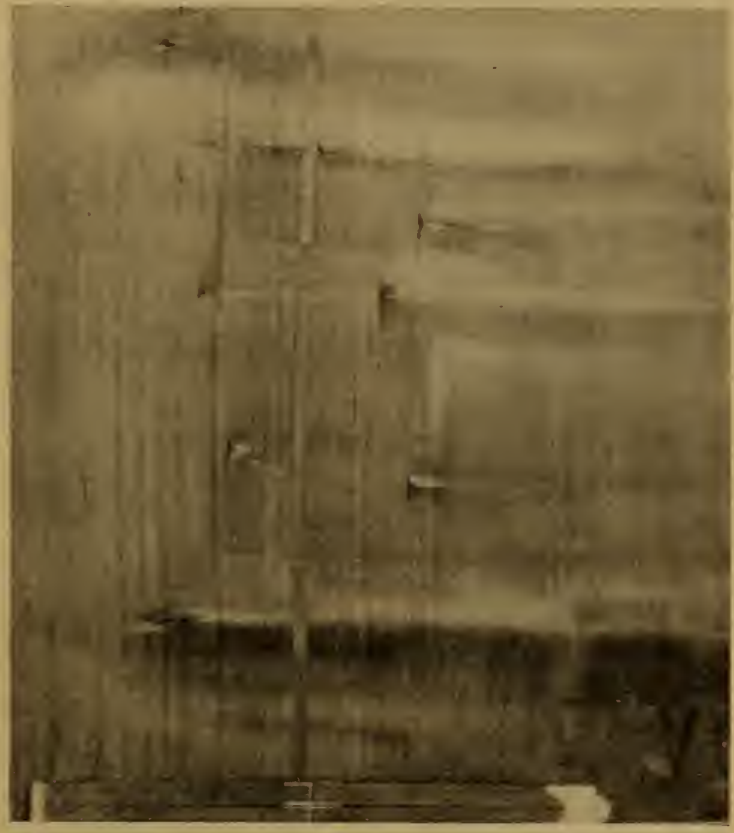
(fig.17), Salixlongipes, S. lærigata (A. A.), S. toumeyi (A. A.), S.

Fig. 16.-Effects of sapsucker work on wood of black cottonwood (Populus trichocarpa). Checks, stains, buried adrentitious buds, and curled grain.

amygdaloides, S. lasiandra, S. interior, S. sessilifolia, S. missouriensis, S.lasiolepis, S. hookeriana, S. taxifotia (1. 1.), S. sitchensis, S. discolor, and S. scouleriana.

\section{THE BAYBERRIES (MTRICACEE).}

Defects due to sapsucker pecking have been noted in three of the four native arborescent species of this family-the bayberry, wax myrtle, and California bayberry. The blemishes vary from small brown checks to large open ones and black stains up to 2 or 3 inches square, but on account of the limited use made of the wood they are of economic significance in but one species, the California bayberry, which is used in cabinet work and turnery. 
THE WALNUTS ANI HICKORIES (JUGLANDACEE).

The trees of this family furnish the most costly woods produced in the United States. 'They are frequently attacked by sapsuckers

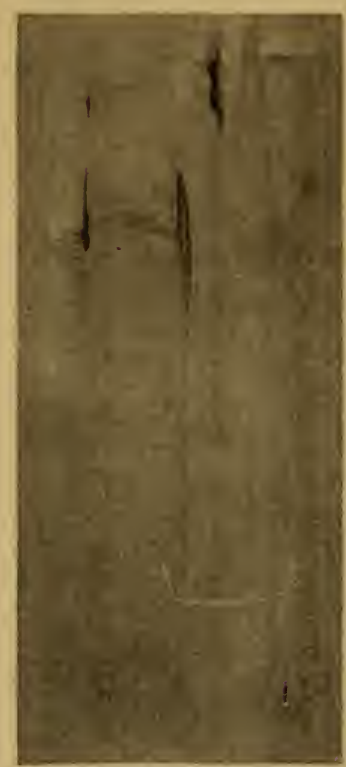

Fig. 17.-Effects of sapsucker work on wood of Carolina poplar (Populus deltoides). Large checks and gnarled grain. and the resu'ting injuries are severe and often ruin the lumber, except for fuel or heavy construction. Serious defects have been observed in the wood of 12 of the 19 native species, and probably all of them are subject to sapsucker injury. In black (fig. 18) and in Texan walnut, the defects consist of heavy black stains running far along the grain and black checks, either filled with loose plugs or open and knotty. They spoil the ornamental appearance of these woods.

In hickory (Pl. X, figs. 2 to 4, and Pl. XI, fig. 1) the blemishes consist of open black checks (varying in size up to 2 by 4 inches), sometimes soft walled or partly filled with spongy growth, frequently connected with gnarly fissures up to 2 inches in length, which usually extend toward the bark. These are surrounded by brown or black stains called iron streaks, which penetrate more or less wood adjoining the wound and follow the grain sometimes for many feet. They are serious in all the species examined. Mr. Carlos G. Bates of the Forest Service says: "The hickory is oftentimes damaged beyond the effect of the streak. As the wound made by the bird heals over, a small lump is formed over the spot, and stimulated to hypertrophied growth (by the lack of pressure where the bark has been removed). This in time becomes a sort of tubercle standing out at right angles to the stem and protruding through the bark. Sooner or later it ceases to grow, and the normal growth of the tree buries it, leaving a flaw in the wood equal to a large, loose knot."

The abundance and extensiveness of stains and gnarly growth in hickory unfit the wood for ornamental purposes, and the fact that the iron streaks make the wood harder to work and that checking takes place readily along them, spoils the wood for many of its most important uses. "The wood is heavy, hard, very strong, tough,

Fig. 1S.-Effects of sapsucker work on wood of black walnut ( $J$ uglans nigra). Holes and dark stains. (From Hopkins.) 


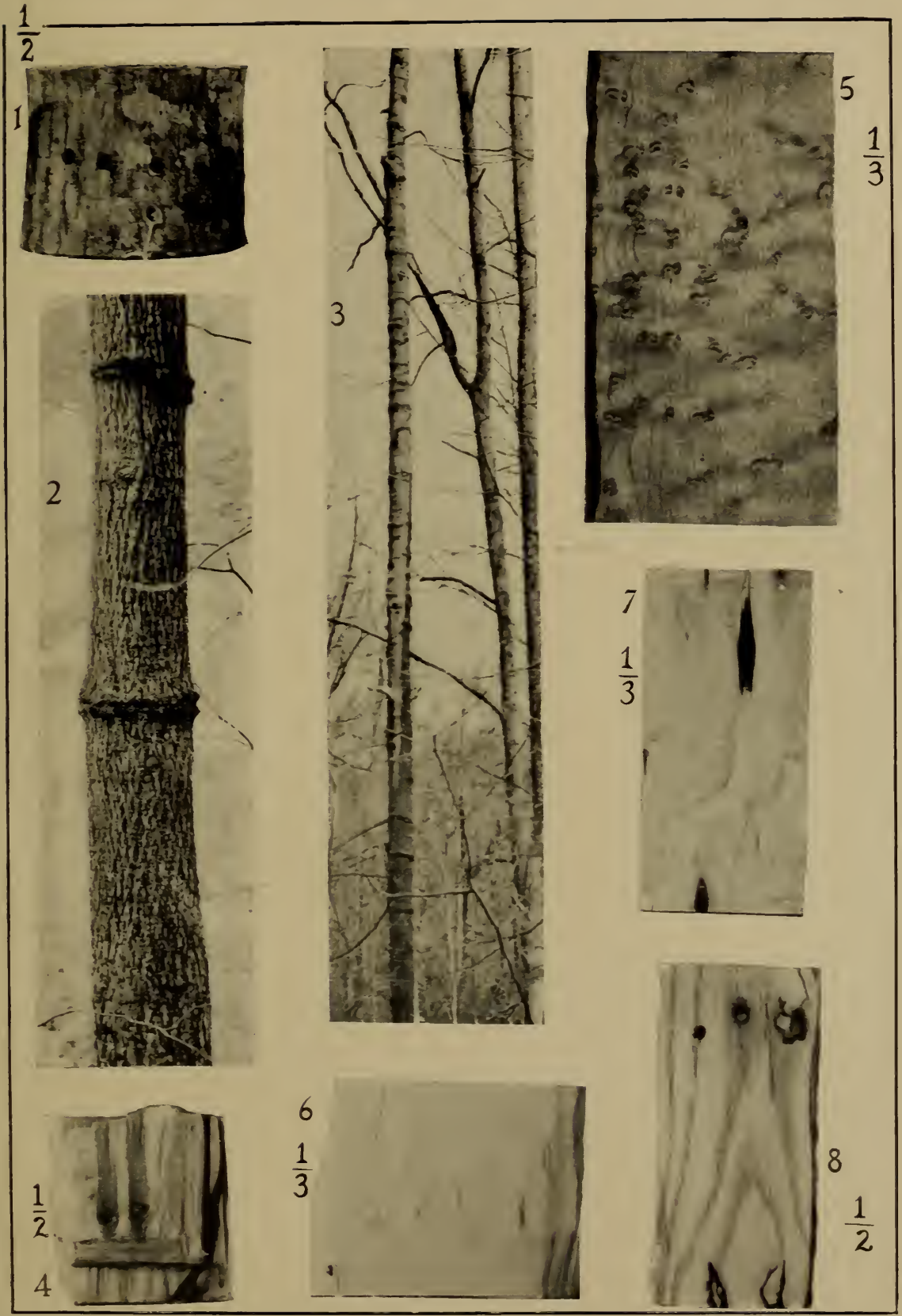

WORK of SAPSUCKER ON HICKORY, MAPLE, BASSWOOd, AND CHESTNUT; BIRD'S-EYE.

[1. The beginnings of a girdle on mocker nut. 2, Well-dereloped girdles, tree 2 feet in diameter. 3 , Mocker nut, killed br sapsuckers. 4, Sapsucker pecks and stains in sugar maple wood. 5. Natural bird's-ese in sugar maple. 6 . Sapsucker bird s-eve in same wood. $\overline{7}$, Stains due to sapsucker pecking in basswood. 8 , Stained knotty checks in chestnut.] 

flexible, but not durable in contact with the soil. It is used extensively in the manufacture of carriages and agricultural implements and for ax and tool handles. There is in consequence a good demand for the lumber at a high price." ${ }^{1}$ "It is the general impression of the hickory users, ... that the supply is rapidly diminishing. It is certain that the high grades of hickory required for vehicle parts and for other purposes are being obtained only with increasing difficulty. The average value per thousand feet reported for the lumber is exceeded by only one of the 29 leading species manufactured, namely, walnut." ${ }_{2}$ Defects in hickory caused by sapsuckers are specifically mentioned in the Inspection Rules of the Hardwood Manufacturers' Association, where it is stated that the third grade of material is "to consist of the light-weight wood . . . and will admit of small bird pecks, black streaks, and small knots." Hickory wagon and implement stock must be clear with the exception of axles, single and double trees, and neck yokes, "which will admit bird pecks, streaks, and solid knots that will not impair the strength of the piece." A loss of about $\$ 20$ per thousand feet of lumber is caused by the reduction in grade on account of bird pecks, and the aggregate loss is very large on account of the prevalence of sapsucker work on hickories throughout their ranges. On Plummers Island, Md., 10 of the 34 hickory trees on a certain area bore sapsucker work, and on another area not far distant on the mainland 38 out of 156 , a little more than 25 per cent.

Not only do bird pecks occur on a considerable percentage of hickory trees, but they are characteristically abundant on individual trees. Many trees are ringed from top to bottom by sapsucker work, and not infrequently trees are considerably distorted by large girdles.

Mr. A. T. Boisen, formerly of the Forest Service, writes as follows:

The most serious injury to which the hickories are liable is that known as the "bird peck." .. . The damage done in this way is'very extensive, and an immense amount of wood, perhaps as much as 10 per cent of the merchantable material, is left in the woods on account of bird pecks. ${ }^{3}$

Mr. Carlos G. Bates, of the Forest Service, says:

The damage done by the sapsucker is immense, and may amount to 30 per cent of the total value of the hickories in some localities, and for the entire United States at least 10 per cent.

On the basis of the percentages given by Messrs. Boisen and Bates (and according to the writer's experience their estimates are conservative) the loss to hickory producers of the United States on hickory left standing on account of bird pecks amounts to about $\$ 600,000$ per year. To this must be added the loss sustained by the producer 
or lumber dealer on the cut timber graded out by the manufacturers' requirements in regard to bird pecks. The writer has been told of a case where $4 \frac{1}{2}$ cords of hickory timber were rejected from a lot of 7 cords by this inspection. Finally, in spite of all the care exercised by the manufacturer to secure perfect stock, bird pecks unnoticed before appear in the finished product (see Pl. XI, fig. 1). In the case of hambles at least, this is true of quite a noticeable proportion of the output. Mr. II. A. Tatem, president of the Winston Handle Co., Winston-Salem, N. C., writes as follows:

No matter how good the handle, a bird peck generally puts it way helow cost. There are many high-class handles with a very slight peck, but down they go.

There is no trouble in disposing of them, beause they are splendid value for the cost to the consumer. The peck does not injure the handle itself, it is simply defective in appearance.

While we can not agree with the statement that a bird peck never injures a handle, yet our correspondent goes straight to the root of the trouble not only with bird pecks in hickory but in many other woods. Market values depend on appearance more than on quality. However, in the case of hickory the injury is real enough. The gnarly growth caused by the healing of sapsucker wounds is exceedingly objectionable in lumber prized above all things for its straight, clear grain and flexibility. This gnarled condition, as well as the iron streaks which make the quality of the wood fibers uneven, lowers the value of the handles because of the tendency of the grain to rough up or splinter. A member of the Forest Service has stated to the writer that this trouble more than any other would lead him to grade out bird-pecked handles. Uneven quality of the grain is watched for very closely in hiandles purchased for the Forest Service.

Mocker yut (IIicoria alba).-Specimens were collected in Fairfax County, Va., March 21, 1909, from a tree bearing abundant sapsucker work, including several conspicuous swollen girdles (Pl. X, fig. 1). It is clear that the sapsucker when attacking this species punctures one or more layers of sapwood. The excavations do not heal perfectly, but persist as small cavities with radiating fissures, all very darkly stained. A cross section through the tree at the level of one of the protruding girdles ( Pl. X, fig. 3) shows many concentric series of stains, evidence that the ring of punctures had been pecked open year after year. Isongitudinal sections show the usual appearance of these stains in hickory lumber (Pl. X, fig. 2)-namely, very dark iron streaks up to an inch in wirlth, which extend a foot or more both up and down along the grain. The wood shows a distinct tendency to check or split along the course of the stains.

In a specimen of mocker nut from Cloverdale, Ind., the iron streaks extend through from 10 to 12 annual rings of wood, and checks from the wounds have required the deposition of from 5 to 6 annual rings 


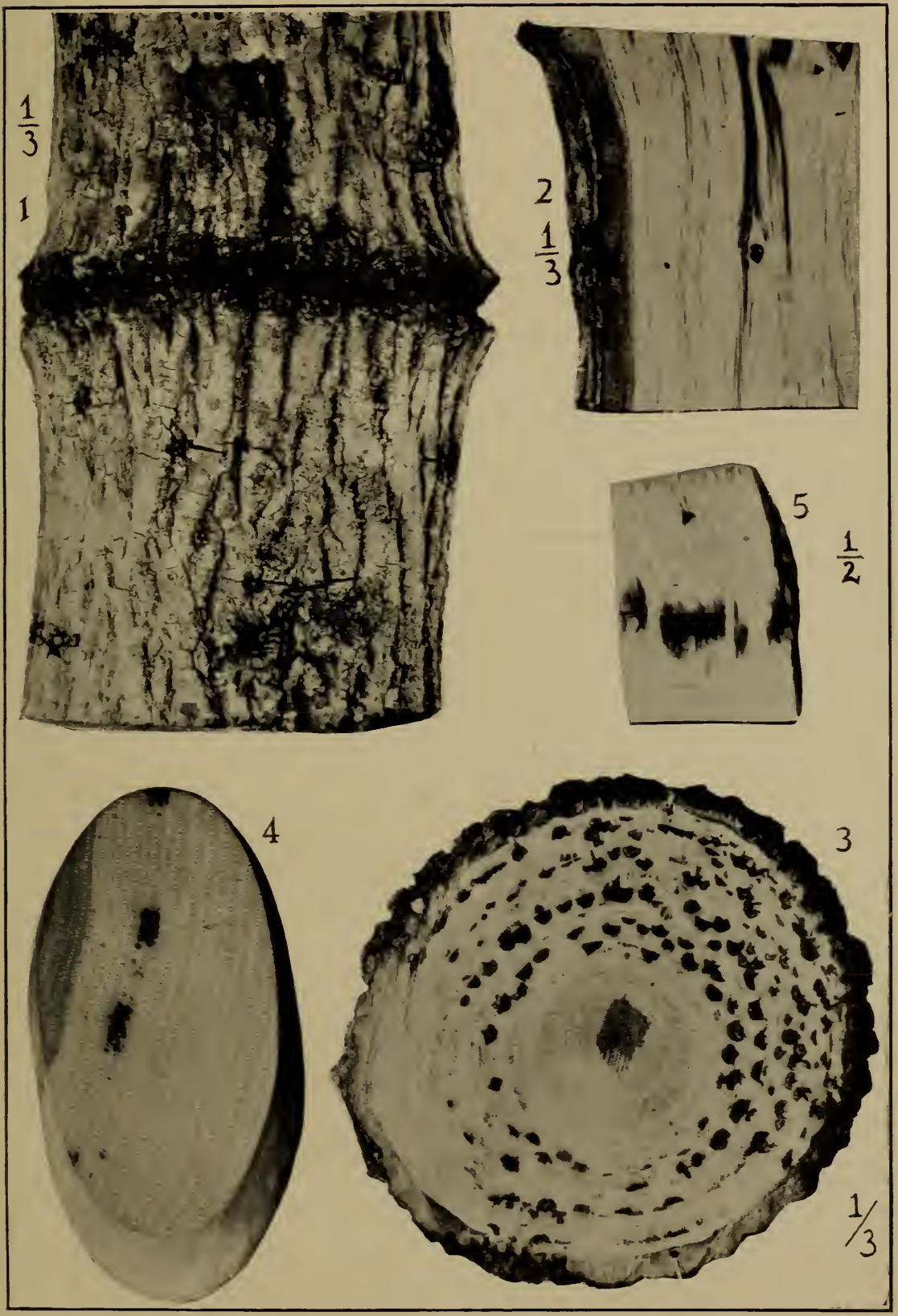

WORK OF SAPSUCKER ON HICKORY AND OAK.

[1, Near view of a swollen girdle on mocker nut, 2. Radial section through a girdle showing iron streaks. 3, Cross section; checks and iron streaks. 4, Same defects on butt of an $\mathbf{a x}$ handle. 5, Stains produced by sapsucker pecking in western white oak.] 

to close them. The unusual extent of the stains in this sample suggests that they spread after complete closure of the sapsucker wound, and the specimen gives actual evidence that they do so spread for at least two years after the original peck is entirely healed.

The defects in mocker nut are very conspicuous and objectionable. J. B. Burris, of Cloverdale, Ind., who sent in the last specimen described, writes: "Recently a large sale of the timber was made, but on account of the condition of the trees they were refused as being worthless for lumber. The discolorations... sometimes run entirely through the length of a tree, though frequently the lower portion of the tree is free from the markings. ... Upon inquiry I find that in some localities more than half the hickory trees are affected in this way and thus rendered worthless except for firewood." (Dec. 9, 1901.)

SPECIES OF JUGLANDACEE BLEMISHED.-Black walnut (H.), Texan walnut, nutmeg lickory, pecan (fig. 19), Texan pecan, bitter pecan, bitternut (A. A. and A. M. and F.), mocker nut, big shellbark (H.) (fig. 20), southern shellbark, pignut, and woolly pignut.

THE HORNBEAMS AND BIRCHES (BETULACEæ).

Blemishes in the wood of trees of this family are usually small, consisting of brown stains and sound brown to black checks. In some cases, especially since curly grain and bird's-eye are often present, the effect is ornamental (fig. 21), but probably ornaments as well as defects are of no economic importance in the hornbeams. No serious defects have been

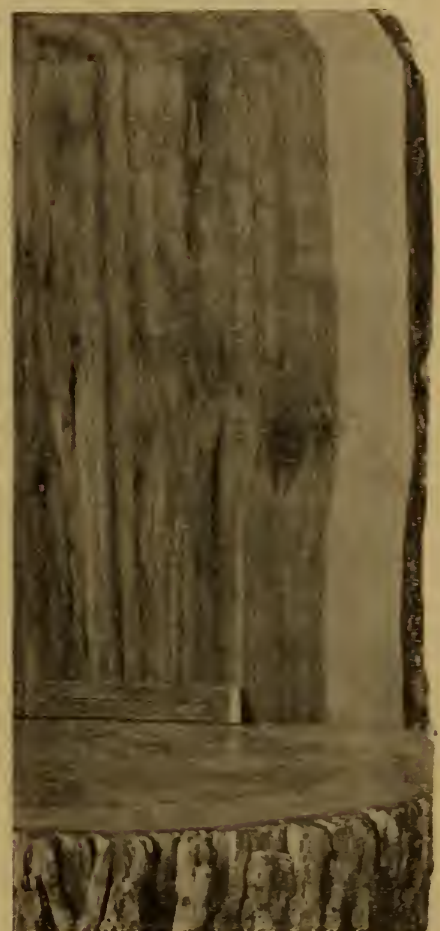

FIG. 19.-Effects of sapsucker work on wood of pecan (Hicoria pecan). Knotty checks and iron streaks. found in the birches.

Species of Betulacee blemished.-Hornbeam (H. and A. A.) (fig. 21), hop hornbeams (Ostrya virginiana and Ostrya Finoultoni), canoe birch, and sweet birch (according to Dr. Hopkins).

\section{THE BEECHES, CHESTNUTS, AND OAKS (FAGACEE).}

The woods of this family are more widely used than those of any other deciduous trees. They are valuable for general construction, cooperage, interior finish, and cabinetmaking, for which purposes 
the wood must be sound, and for the latter two uses have few blemishes. Many of the species are attacked by sapsuckers, and the resulting defects in the wood are serious. Defects have been found

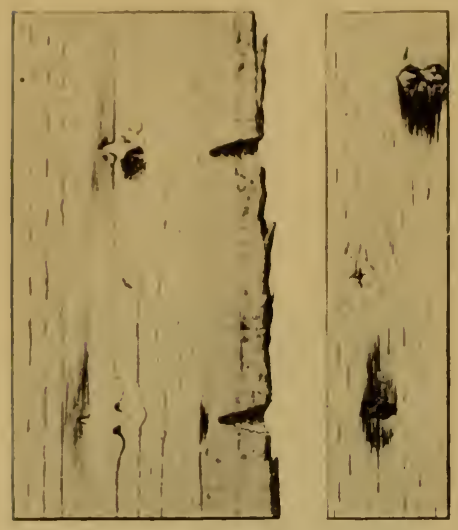

Fig. 20.-Effects of sapsucker work on wood of big shellbark (IIicoria laciniosa). Stains and gnarly growth. (From Hopkins.) in the beech, chestnut, and chinquapin, and in all they are detrimental to the appearance of the wood, and in small pieces they diminish the strength. Ornamental curled grain is sometimes produced in beech, but black cavities and extensive brown stain also are formed, which eounterbalance the good effect of the desirable grain. In chinquapin and chestnut (fig. 22 and Pl. IX, fig. 8) large open checks result from sapsucker work, which seriously blemish and weaken the wood.

In oak, sapsucker blemishes or bird pecks are almost invariably open knotty checks, sometimes small but usually half an inch square or larger. The checks and the immediately adjoining wood are usually hearily stained and the checks are sometimes partly filled or surrounded by loose soft or rotten wood. The wood over the defects is more or less stained and distorted. Checking through the blemishes commonly occurs, and the weakening of the wood is further shown by the tendency of windshakes to occur along the line of sapsucker injuries. Defects have been observed in the wood of 19 oaks, in 17 of which they are serious enough to cause marked loss in value of woods so prized for furniture, interior finish, and other ornamental uses, and in 2 of

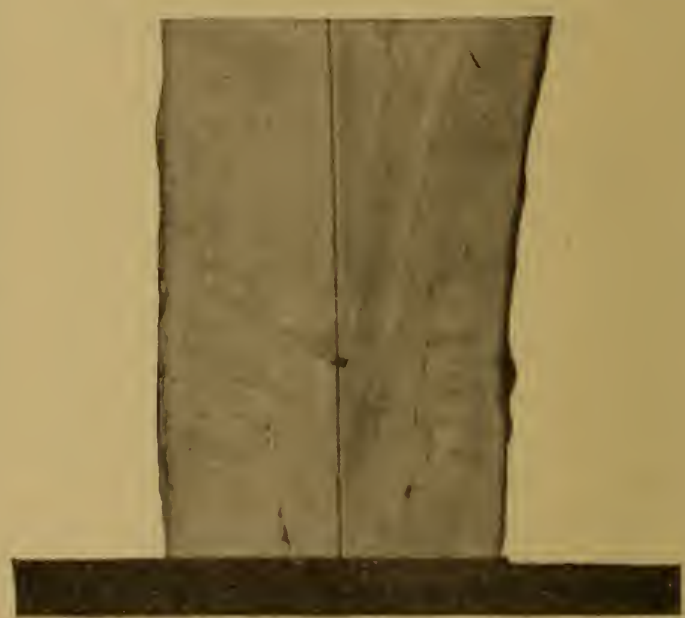

FIG. 21.-Effeets of sapsucker work on wood of hornbeam (Carpinus caroliniana). Small checks and stains. which, black oak (fig. 23) and cow oak (fig. 22t), they are so large as to spoil the wood for any but the coarsest construction. The large, open, knotty checks so characteristic of sapsucker work 


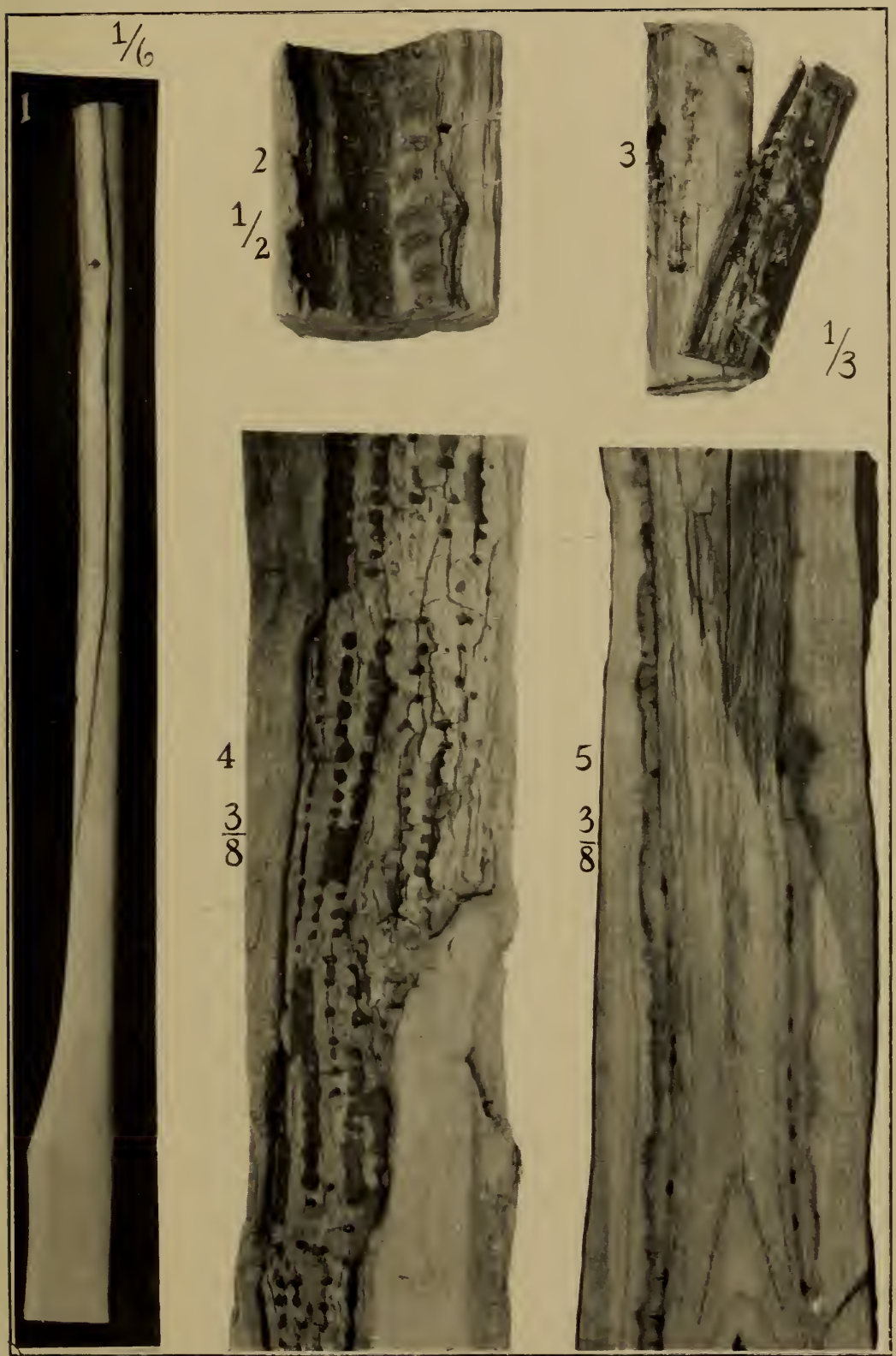

Work of Sapsucker on Hickory, Pitch Pine, Red Cedar, and Sassafras.

$[1$, Checks and iron streak in hickory handle. 2, Stains and resin deposit in pitch pine. 3, Stain, resin deposit, and tubercles in red cedar. 4, Sassafras, partly killed br sapsucker pecking and healing over. 5, Longitudinal section of same; checks and stains.] 

in oak (present in specimens of 14 of the 19 species examined) effectually spoil the wood for tight cooperage, one of its most raluable uses.

White-oak lumber is extensively used for ornamental purposes and yields the largest returns when so used. It is very carefully graded, and the inspection rules of the National Hardwood Lumber Association specify that "stains and streaks in oak are a serious defect, and inspectors are cautioned to be careful in estimating their damage to pieces, as ofttimes they will reduce them below the grade of firsts and seconds." Reduction in grade means the loss of about 30 per cent from the best selling price. A great deal of white oak is cut into reneers for finishing purposes, and knots and stains are very objectionable. At a veneer plant in Winston Salem, $\mathrm{X}$. C., visited by the writer, all the material showing sapsucker work was found among the lowest grade or cull stuff. Although the cause of the defects was unknown to the millmen, it was evident that blemishes due to sapsucker work are incompatible with high quality in white-oak veneer.

BeECH (Fagus grandifolia).-A piece of this wood which is not large enough to include the original wounds shows a distinct curl in the wood. The bark has healed with a strong inward projection, which has produced a depression in each new wood layer. The original sapsucker holes were from a fourth to half an inch apart, but the ridge on the inner side of the bark is continuous, with slightly elerated tubercles under the punctures. In such a case, if the sapsucker work is old and many annual rings have been curled, so that the stains can

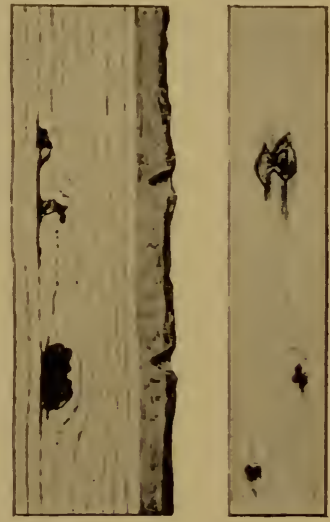

FIG. 22.-Effects of sapsucker work on wood of chestnut (Castanea dentata). Large gnarly checks. (From Hopkins.) be aroided in sawing the wood, the effect of the bird's work is to enhance the ralue of the wood for ornamental purposes. Howerer, unless these conditions are met, ornamental features do not mitigate the effect of certain blemishes that are produced. Gnarly growth takes place at the original wound, which is only partly filled and is surrounded by very black stain. A lighter brown stain also extends some distance along the grain. These blemishes are so decided that they would certainly be cause for lowering one or more grades the lumber cut from this tree. (Specimens from Morgantown, W. Va.)

Chestrut (Castanea dentata).-Sapsucker work in chestnut produces large (three-fourths by one-fourth inch) carities, black stained, and partly filled by loose, black, knotty growth (fig. 2.2 and Pl. IX, fig. 8.) - The wood is weakened by these cavities, as is shown by its 
checking on a line with them. For cabinet or other work requiring sightliness, or where strength is required in any but large pieces, chestnut with abundant sapsucker work would be useless. (Specimens from Pickens, W. Va.)

Вцаск ОАк (Quercus velutina).-The defects produced in this tree

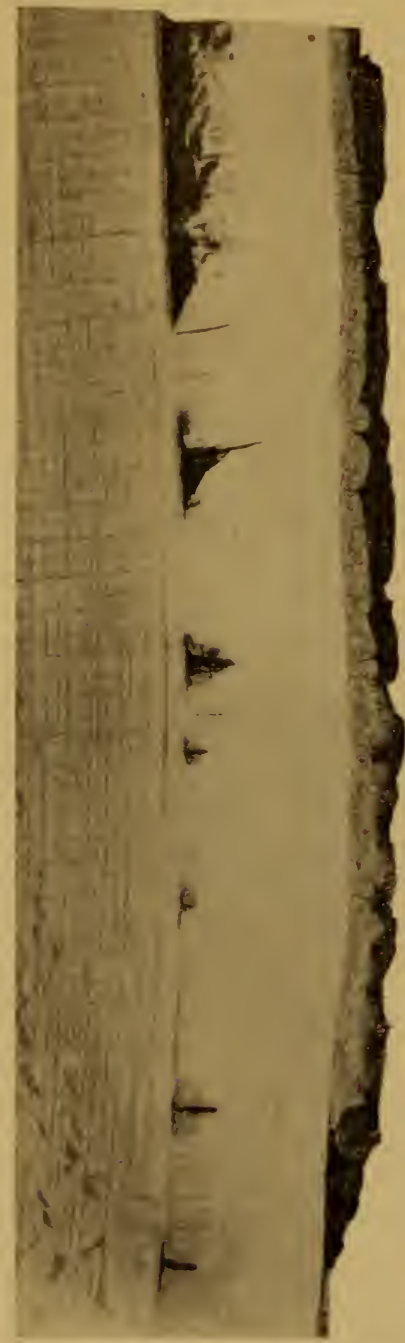

FIG. 23. - Effects of sapsucker work on wood of black oak (Quercus vclutina). Large gnarly checks.

by sapsucker pecking are large, widely open, black-walled checks surrounded by much gnarled and stained wood (fig. 23). These checks rary in size up to 1 by $\frac{1}{2}$ by 5 inches and constitute defects so extreme that the lumber is useless for any structural purpose. (Specimens from Abbeville, I La.)

Cow OAK (Quercus michauxi).-The defects produced in this wood are large to very large black gnarly checks. These are sometimes contiguous, forming a stained crack following an annual ring (fig. 24), 4 inches horizontally and 2 to 3 inches vertically. Open fissures extending toward the bark and surrounded by much gnarly woorl are characteristic. The wood under the wounds is usually soft and rotten. The specimens examined show that windshakes tend to occur along the line of sapsucker defects. The blemishes are large and numerous, hence serious. Many windfallen trees examined by the writer at Abbeville, La., were so filled with defects that they would not afford a single board of marketable dimensions. The wood is useless except for fuel.

Colorado White OAK (Quercus leptophylla).-Numerous open knotty checks stained dark brown occur in a trunk of this species attacked by sapsuckers. They are surrounded by gnarly wood, and some are one-half inch by 1 inch in size, being equivalent to open knots of those dimensions. When several occur along the same wood layer they constitute a line of potential fracture, thus rendering the trunk more liable to injury by wind-shake. (A. A. and A. M. 301.)

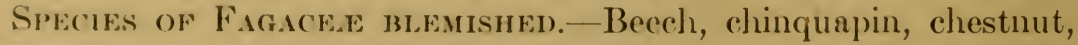
tanbark oak, turkey oak, black oak (fig. 23), 'Texan oak, Spanish oak, 
water oak (Santee Club, South Carolina), laurel oak, white live oak (fig. 25), live oak (Santee Club, South Carolina; Glen Rose, Tex., fig. 26), net-leaf oak (A. A.), Texan white oak, shin oak (fig. 27), Chapman oak, chestnut oak (Seren Locks, Md.), cow oak (fig. 24), western white oak (Pl. X, fig. 5), Colorado white oak, post oak (Longbridge, La.), and white oak (H.).

\section{THE ELMS AND HACKBERRIES}

(ULMACEE).

Defects due to sapsuckers have been noted in the wood of six kinds of elms (including water elm), in three of which they are serious, and in two species of hackberry, one of which is much blemished. The defects vary from light brown stains of no economic significance to black checks, sometimes large and often filled with loose or soft woody tissue.

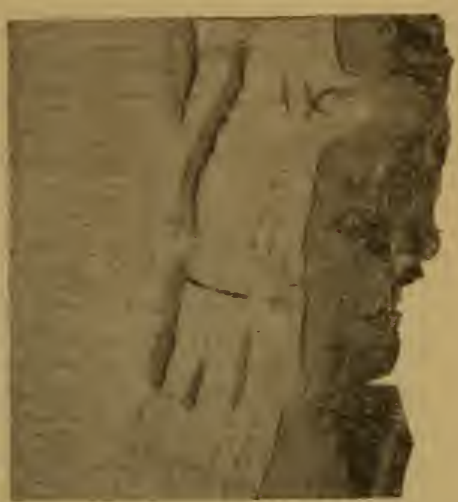

FIG. 24.-Effects of sapsucker work on wood of cow oak (Quercus michauxii). Stained and soft-walled checks.

All of the elms furnish wood of commercial importance, and sapsucker work reduces its value or spoils it for such representative uses as the wooden parts of agricultural implements and rehicles,

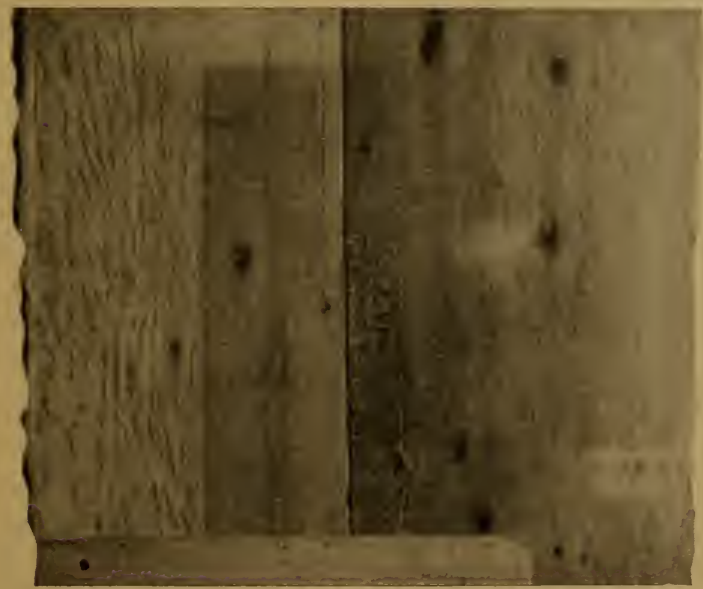

FIG. 25.-Effects of sapsucker work on wood of white live oak (Quercus chrysolepis). Knotty checks. cooperage, and furniture. Hackberry wood is sometimes used for furniture, for which sapsucker defects unfit it.

Thite Elis ( $C 7 \mathrm{mus}$ americana).- - H e a l ed sapsucker wounds in this tree vary from small carities partly filled with powdery tissue to large open knots, sometimes an inch or more in length and involving three to four annual layers of rood (Pl. VIII, fig. 2). These knots, as well as the wood immediately surrounding them, and sometimes for some distance along the grain, are black stained. When sapsucker work is abundant, the whole body of the wood is sprinkled 
with stains, the grain is gnarled and in some cases (PI. VIII, fig. 1) strongly bent outward, and the wood is unfit for any of the ordinary uses of the lumber except fuel or coarse construction. (Specimens from near Scotts Run, Fairfax County, Va.)

Slippery alm ( Tlmus fulva).-The defects resulting from moderate sapsucker work are short (one-fourth to one-half inch) wary checks surrounded by black stain extending up to one-half inch both vertically and horizontally on the surface of the wounded annual ring, and by light brown stain for a much greater distance. The stains

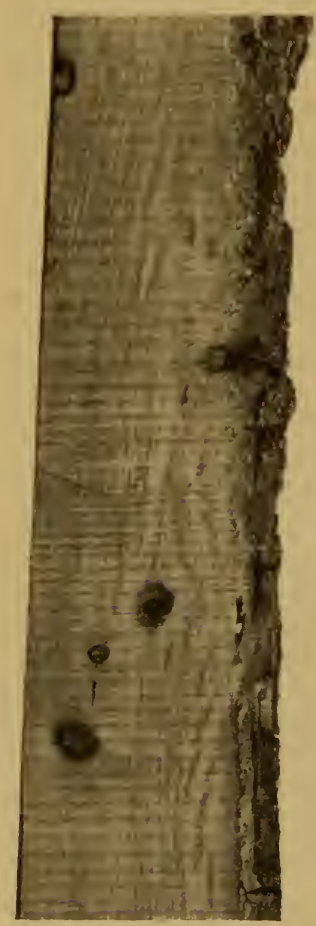

Fig. 26.-Effects of sapsucker work on wood of live oak (Quercus virginiana). Loose knots and stain. penetrate the wood under the wounds. Where several pecks are close together, the defeets are much worse, being open knotty checks up to $1 \frac{1}{2}$ square inches and with open fissures extending one-half inch or more toward the bark (fig. 28). These large defects are stained black and are surrounded by brown stain extending 4 inches or more. The grain is curled over the pecks. The blemishes seriously affect both strength and beauty. (Specimens from Longbrilge, La.) A trunk from Missouri ( $\Lambda$. M., 27S) contains small black checks and brown stains resulting from sapsucker work.

Hackberry (Celtis mississippiensis).Healed sapsucker punctures in this species appear as transverse dark brown stains from which lighter brown stains run several inches both up and down the grain, and from which also open checks, more or less filled with easily removable soft tissue, extend toward the bark for varying distances up to an inch (fig. 29). These checks are from one-fourth to one-half inch wide. The defects injure the lumber in both appearance and strength. (Cottonport, La., Feb. 14, 1910.)

SPECIES OF ULMACEE BLEMISHED.-Rock elm, winged elm, white elm, slippery elm, water elm (А. M.), Celtis occidentatis (F.), and Celtis mississippiensis.

THE FOLR O'CLOCK FAMLY (NTCMAINACE.E).

The wood of blolly (Torrubia longifolia), the only native tree of this family, is sometimes blemished by small open knotty checks with little stain but much gnarly grain. 


\section{THE MAGNOLIA FAMILY (MAGNOLIACEE).}

Small, intensely black stains, the effects of which are confined to the wood immediately adjoining the original injury, result from sapsucker work in bull bay (Longbridge, La.), the only defective magnolia wood examined; and long black stains following the grain are produced in the tulip tree, one of the most useful of our native trees. These blemishes unfit the lumber for its most profitable uses.

TLLIP TREE, YELLOW POPLAR, OR WHITEWOOD (Liriodendron tulipifera).-Tulip trees are very commonly worked on by sapsuckers and frequently are covered with girdles and single punctures from top to bottom. In the healing of sapsucker wounds, inward projections are usually formed on the inner side of the bark, and when close together they combine into a low irregular ridge. These elevations cause depressions in the succeeding annual rings and a curly condition of the grain which in tangential section appears as bird's-eye (Pl. XII). This is often abundant in yellow poplar and enhances the beauty of the wood. Bird's-eye is, however, accompanied by holes and stains resulting from the original wounds, and while some pieces showing bird's-eye and not the defects can be secured from every tree showing sapsucker work, probably the proportion of such boards or veneer from any tree is not large. To have the greater part of the wood ornamented and at the same time free from sapsucker

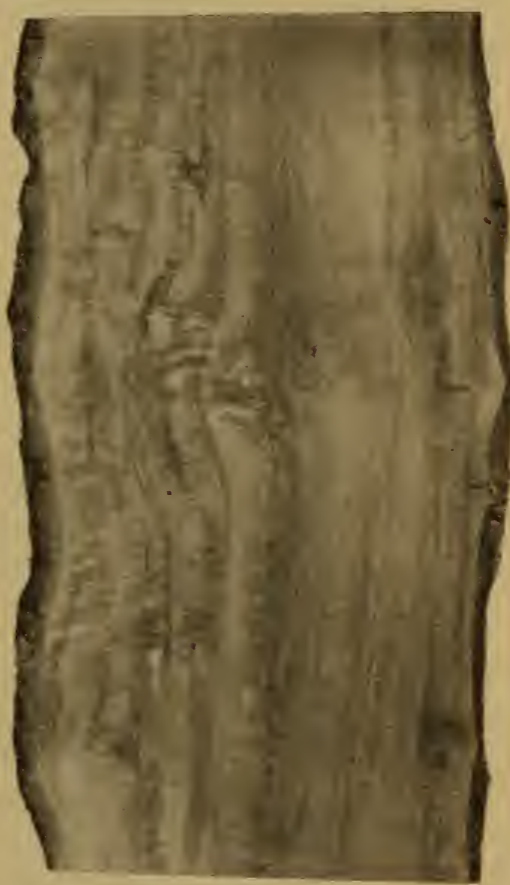

FIG. 27.-Effects of sapsucker work on wood of shin oak (Quercus undulata). Checks, stain, and gnarly grain. defects would require that the tree be liberally punctured in one or a few successive years and left untouched thereafter. But this is not the way sapsuckers usually work. Favorite trees are moderately pecked year after year for a long time; hence stains are produced throughout the wood. If a tree is only sparingly pecked for one or a few years, the ornamental effects will be inconsiderable, and if vigorously attacked during a similar period it is likely to die. On the whole, therefore, probably not many tulip trees can be found in which the wood shows many of the farorable results of sapsucker 
work and fow of the aceompanying blemishes. The matter is of no consequence in wood intended for crates, boxes, and composition boards. But tulip) lumber figures extensively as a finishing material,

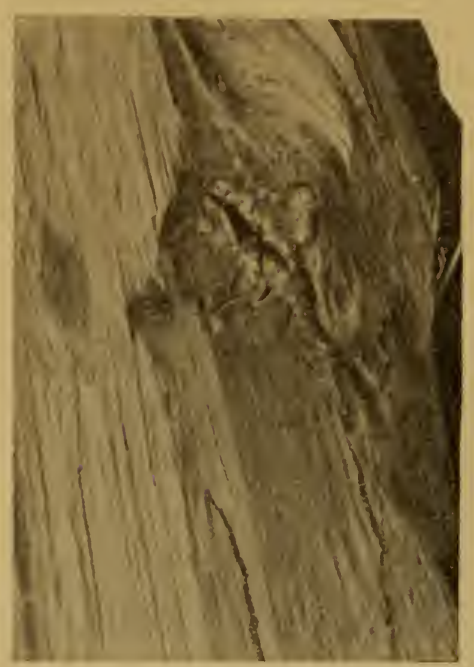

FIG. 28. - Effects of sapsucker work on wood of slippery elm (Ulmus fulva). Large check and stains.

seriously affected. The defects observed in the three species have little in common except a tendeney to extensive lateral staining around the injured wood rings.

Red BAY (Persca borbonia).--1 large proportion of red bay trecs are vigorously attacked by sapsuckers, and the resulting blemishes are serere. Gnarly open cavities are produced, accompanied by dark brown or black stains which cxtend far along the grain and are sometines contin-

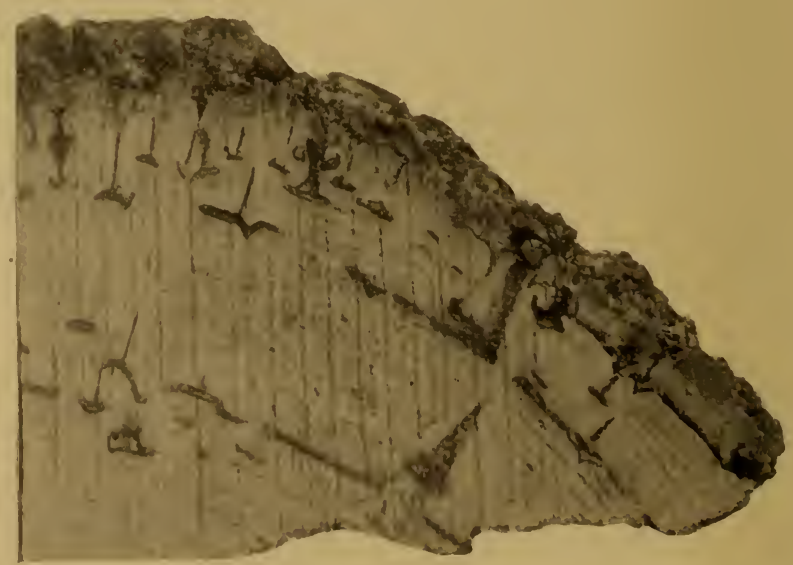

FIG. 29.-Effects of sapsucker work on wood of hackberry (Cellis mississippiensis). Stains and loosely filled checks.

nous ancound the wood rings (fig. 30). Many of the wounds take 15 to 2 () years to heal, producing open fissures extending outward an inch or more. These fissures may be half an inch long vertically 
Plate Xil.

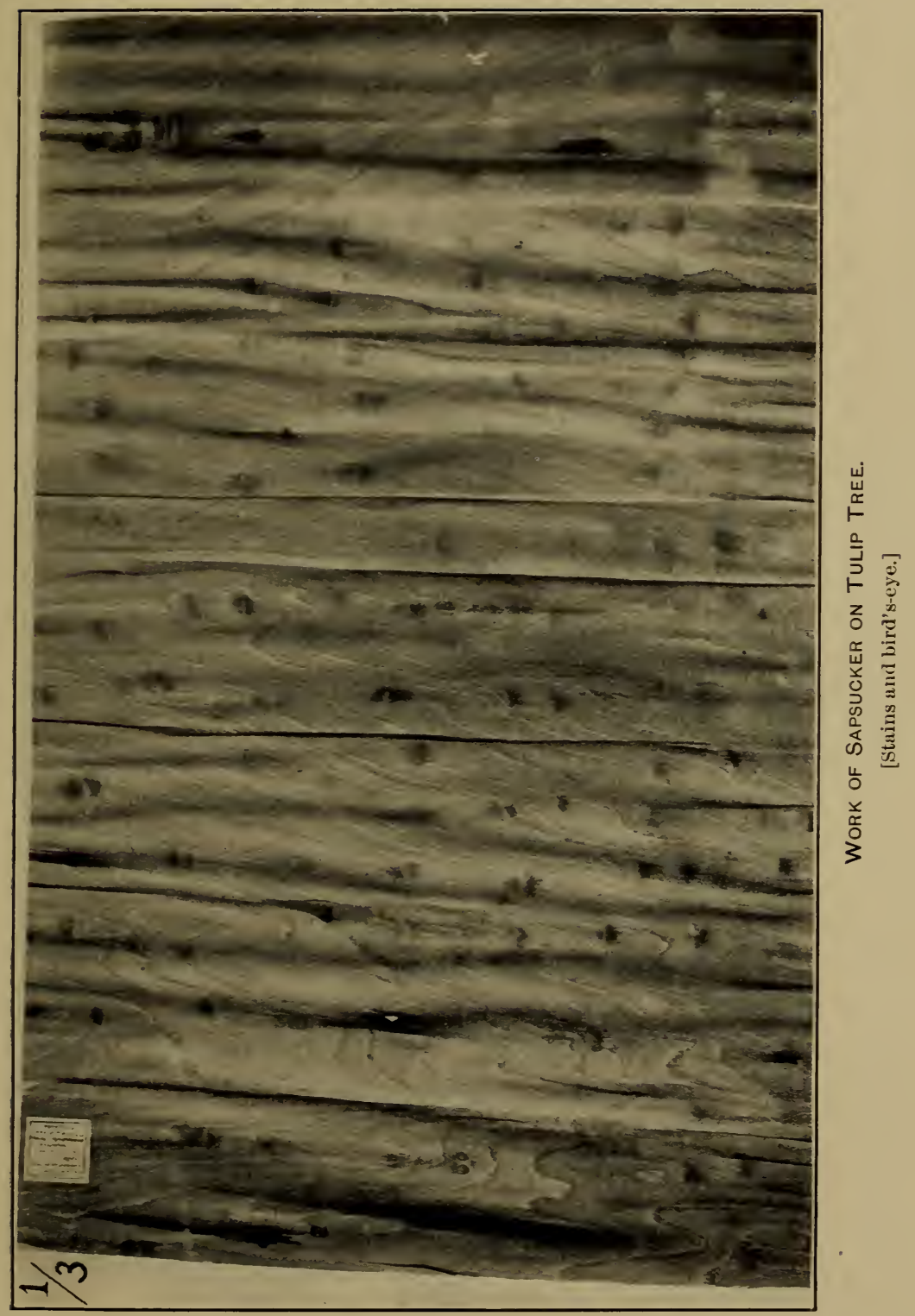



and are walled by soft wood. The stains are heary and may penetrate one or two layers of wood beneath and fire to ten or more layers over the wounds. These defects are exceedingly objectionable and unfit the wood for its limited use in carpentry.

Sassafras (Sassafras variffolium).-The specimen examined is from a tree one side of which had been killed by sapsucker pecking and is now partly corered by new growth. As the wounds themselres hare not healed, their appearance where buried by. succeeding larers of wood is unusual. Along the plane of separation of the new and dead wood are long series of partly filled blackened pecks, with stain all along the line (Pl. XI, fig. 5). The wood covering the pecks is gnarled and full of stained cracks and is worthless for any constructive purpose.

CALIFOR NIA LAUREL (Cmbellularia californica). - Defects resulting from sapsucker work are conspicuous black checks ac-

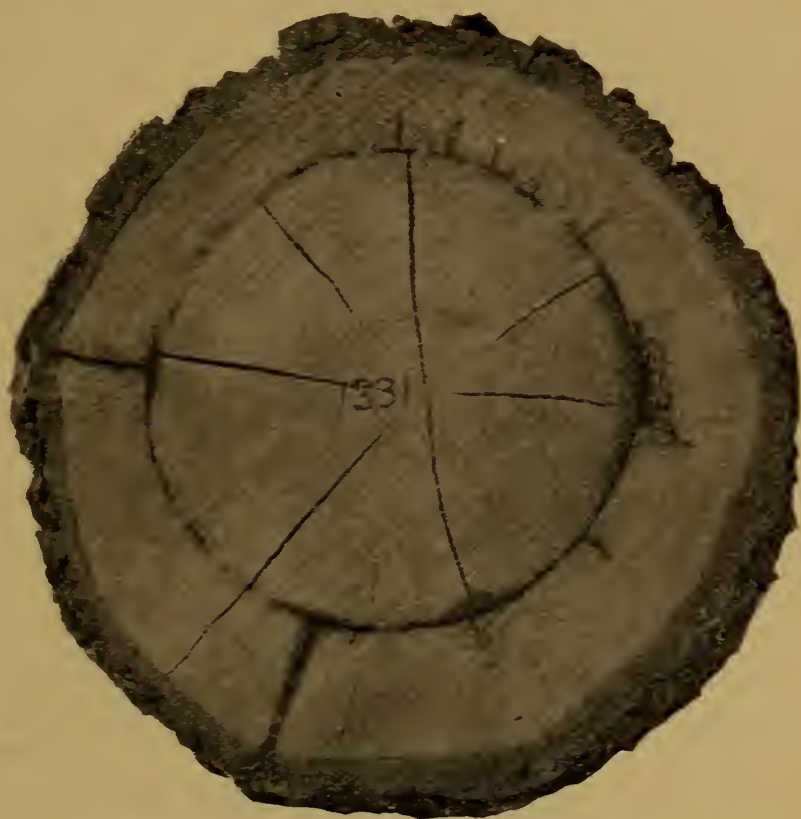

FIG. 30.-Effects of sapsucker work on wood of red bay (Persea borbonia). Stains, checks, and long fissures.

companied by extensive lateral staining and much gnarly wood. They are highly objectionable in this raluable wood.

\section{THE SWEET GCM FAMULY (ALTINGIACEA).}

The wood of the single native species of this family is injured by sapsuckers.

Sweet gum (Liquidambar styraciflua).-In a specimen from Abbeville, La., transverse black stains three-eighths inch wide surround the healed punctures, from which brown stains penetrate the grain vertically half an inch each way. These blemishes are objectionable from an ornamental standpoint but not materially so otherwise. In a trunk from the Santee Club, South Carolina, besides stains which 
are peculiar in that they lie mostly in the two to three layers of wood beneath the wounds, more or less open checks are formed, varying in size up to half an inch square and filled with the white crystallized sap. These blemishes are numerous and seriously decrease the usefulness of the lumber. The wood is valuable, often being substituted for black walnut.

THE SYCAMORES (PLATANACER).

Defects due to sapsucker pecking have been observed in the wood of two (Platanus occidentalis and $P$. racemosa) of the three native sycamores. They are small brown checks and stains and are of no economic importance.

\section{THE ROSE FAMLY (ROSACEE).}

The few arborescent species of this family are not highly valued for their wood, but are used to a small extent for turned articles. The defects produced by sapsuckers, varying from small to large open knotty checks heavily stained, unfit them for this use.

Mountain mahogany (Cercocarpus ledifolius).-Sapsucker punctures produce very serious blemishes in the wood-open, knotty, black-walled cavities, some with crystalline sap deposit. Some of these are fully an inch long, and in many cases a large black fissure extends from them toward or even entirely to the bark, through many annual layers of wood. The lumber is ruined as to both beauty and strength (Eureka, Cal., A. A. 202).

Species of Rosace e BLemished.- Tauquelinia californica, Cercocarpus betuloides, C. breviflorus, and C. ledifolius.

\section{THE APPLE FAMILY (MALACEA).}

Wood of the trees of this family is usually hard and tough and is used to a small extent for mallets, tool handles, and turnery. The defects produced by sapsuckers, when pronounced, make it useless for such purposes, as they increase liability to splitting. They vary from small brown or black stains to large open checks and fissures.

Califoria holly (Heteromeles arbutifotia).-Trunks of this species

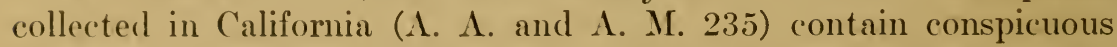
deferts due to sapsuckers (fig. 31). These are large knotty cavities, decply stained and surrounded by much gnarly growth, with long fissures partly or wholly filled with black-stained or white soft growth extending toward the bark. These checks or fissures sometimes exceed an inch in length. The wood is so distorted and blemished as to be uscless except for fucl.

Species of Malace.e BLemished.-Malus angustifolia (A. M.), Malus diversifolia, California holly, Crataegus crusgalli, C. Tacrimata, 
C. opima, C. berlandieri, C. boyntoni, C. collina, C. texana, C. mollis, and C. marshalli.

\section{THE PLUM FAMILY (AMYGDALACEA).}

Defects caused by sapsuckers have been observed in the wood of seven species of this family. Not all these species have great economic ralue, but the wild black cherry furnishes one of our most costly woods. The blemishes in it are typical of those in this family, and they are sometimes so serious as to ruin the wood for any ornamental use.

Wild Black Cherry (Padus serotina).-In specimens from southern Arizona (A. A. and A. M. 1SS) sapsucker defects vary from small to large black checks accompanied by little stain. Specimens from Randolph County, W. Va. (H. 6801a), show large stains up to $1 \frac{1}{2}$ inches long and rarying from yellowish brown to black about the healed wounds. The injuries evidently do not heal readily, as cavities surrounded by gnarly growth are formed. Defects in cherry, which is used almost exclusively for ornamental purposes, are very objectionable. Such

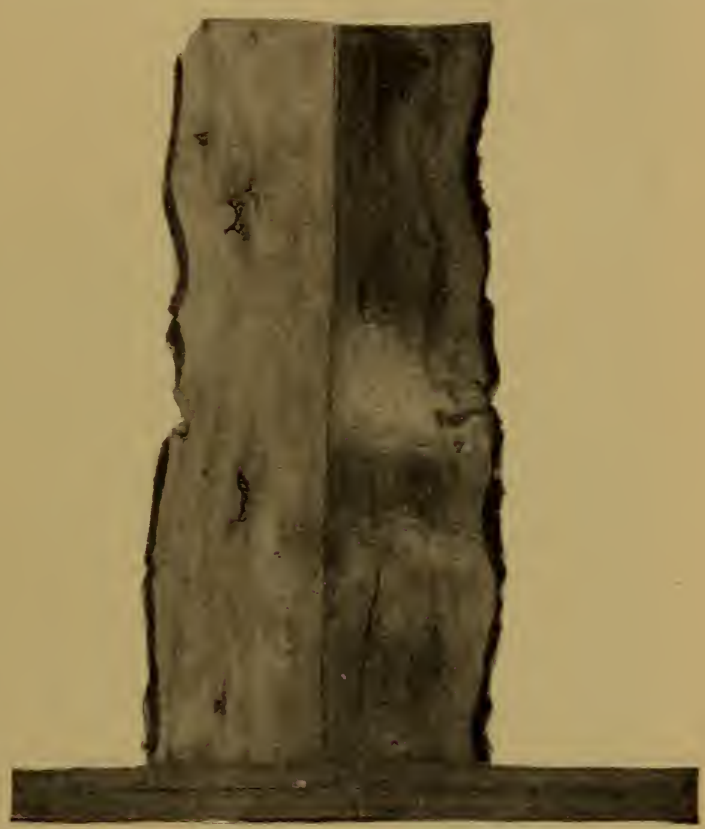

FIG. 31.-Effects of sapsucker work on wood of California holly. (Heteromeles arbutifolia). Knotty checks, gnarly grain, stain, and long fissure.

as are here described would certainly lower the grade of lumber, causing a loss of perhaps 75 per cent from the best selling price.

Species of Amygdalacee Blemished.-Hog plum, wild goose plum, garden plum (F.), bitter cherry, western chokecherry, wild black cherry, and islay.

\section{THE SENNA FAMILY (CESALPINACEE).}

Blemishes caused by sapsuckers have been noted in but one species of this family-the honey locust.

$99068^{\circ}-$ Bull. $39-11-6$ 
Honer Locust (Cileditsia triacanthos).-Brown stains penetrating the injured wood layer are developed at the healed wounds, and they

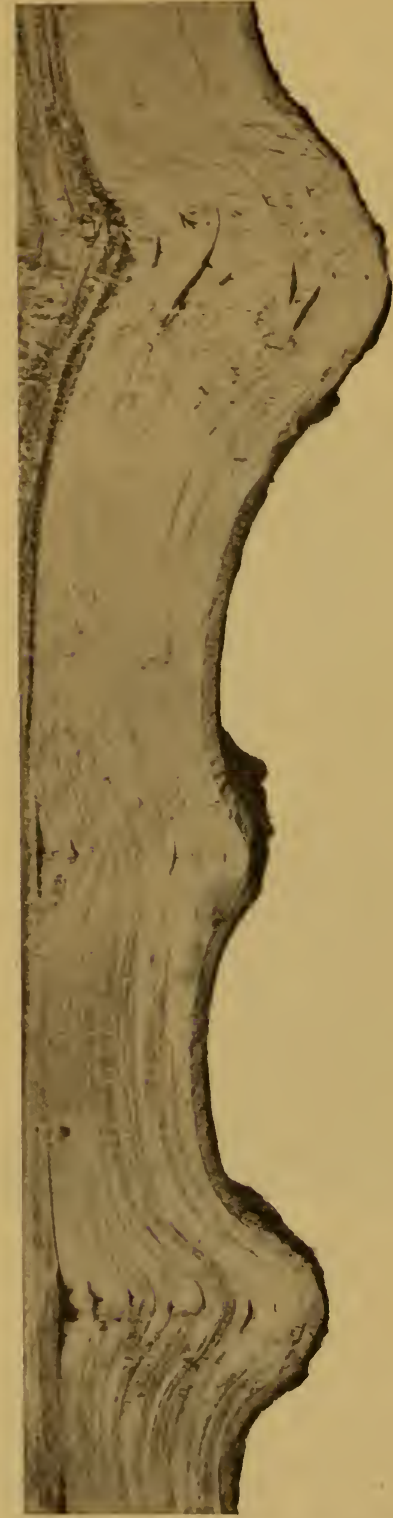

Fig. 32.-Effects of sapiucker work on wood of honey locust (Gleditsia tri.tcanthos). I.ongitudinal section. (hecks, stains, and gnarly grain. are often continuous around the annual ring. In such a case the layer constitutes a potential line of fracture. Many stains are accompanied by open fissures extending outward. These defects are occasionally enlarged by much subsequent pecking until large, ramifying, open, black-stained cavities result. The exterior of the tree is disfigured by large swollen girdles, and the wood in the girdles is gnarled and so full of checks and stains (figs. 32 and 33) that it is useless, except for fuel.

\section{THE RUE FAMILY (RUTACEA).}

But one species of this family is known to be injured by sapsuckers, but it is the valuablesatinwood(Xanthoxylum flavum), which is largely used for furniture and tool handles. Objectionable long dark stains are produced.

\section{THE MAHOGANy FAMily (MELiACEA).}

The single native species of this family, mahogany, a cabinet wood of the highest value, is seriously blemished by sapsuckers.

Mamogany (Swietenia mahagani).-The wood is heavily stained around the original wounds and a lighter stain extends to a considerable depth and far along the grain. Cavities partly filled with brittle black material are formed, and gnarly growth characterizes the wood in the immediate vicinity of the wounds. Curly wood and a large bird's-eye are present in many annual rings succeeding the injury. Both defects and ornaments are produced in this wood, but to get the benefit of the latter the logs must be sawn with reference to the sapsucker work. As this is not practicable commercially, the blemishes probably overbalance the embellishments. 


\section{THE SUMAC FAMILY (ANACARDIACEE).}

The wood of one native and one introduced species of this family is blemished by sapsuckers. The matter is of no economic importance except possibly in the case of the introduced pepper tree. Mr. W. Otto Emerson, of Haywards, Cal., contributes the following note on this species: "I have two old pepper trees beside the house where [the red-breasted sapsucker] has left his marks from year to year. In time this cutting of the bark of the pepper tree causes an enlargement of the limb all around where the holes are; the same occurs in the blue-gum tree, and ruins the wood for commercial purposes."

Species of Axacardiacez Blemished.-Smoke tree and pepper tree.

THE HOLLY FAMILY (AQUIFOLIACEE).

The wood of three species of holly is known to be blemished by sapsuckers. In two of them greenish brown to black checks and pronounced stains spoil the appearance of the wood for pyrography,

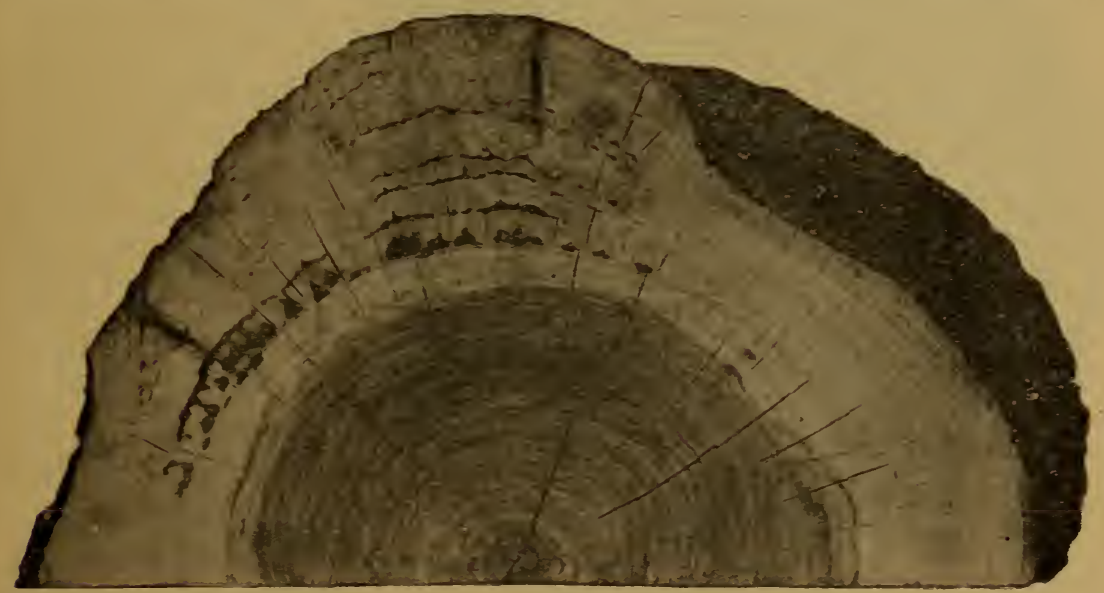

FIG. 33.-Honey locust. Cross section through a girdle. Checks, stains, and gnarly grain. The two long elliptical black marks are nail holes.

one of its most important uses. The checks and fissures produced are objectionable in holly wood used for turnery, because they render, it liable to splitting.

HoLly (Ilex cassine).-Healed sapsucker wounds in this wood are marked by large black stains which tend to be continuous around the injured wood ring. Fissures extend outward from the old pecks, some being open, although three-fourths of an inch of wood has formed outside the punctured layer. These fissures are soft-walled and cause much distortion in the surrounding wood. (Fig. 34.) The defects are very serious and render the wood useless except for fuel (Longbridge, La.).

Species of Aquifoldace alemished.-Youpon, Ilex opaca (Abbeville, La.), and Ilex cassine. 
THE MAPLE FAMILY (ACERACEA).

Defects due to sapsuckers have been observed in the wood of five species of maples, in three of which they are objectionable and may cause lowering of the grade of lumber. The defects vary from small to large brown stains, sometimes accompanied by long lighter stains and by ornamental curled grain and bird's-eye (figs. 9 and 10 and Pl. IX, figs. 4 and 6). They have been fully discussed in one species, the sugar maple, on pages 58-61.

Species of ACERACEA BLemished-Acer rubrum (A. M. and F.), A. drummondi, sugar maple, black maple, and box elder (Fairfax

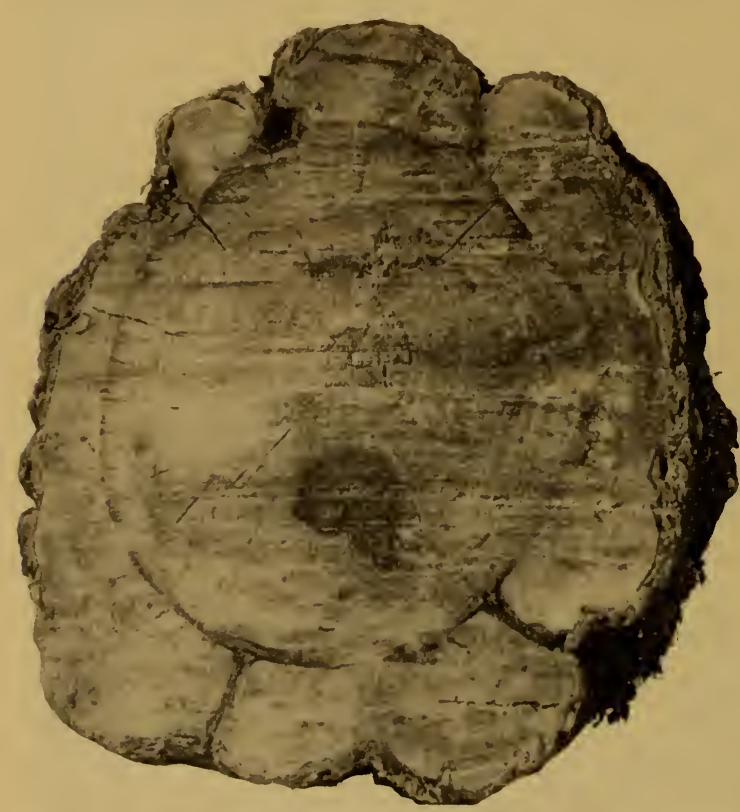

FIG. 34.-Effects of sapsucker work on wood of holly (Ilex cassine). Stains and soft-walled fissures.
County, Va., and Longbridge, La.).

THE BUCKEYE FAMLY (XSCULACEE).

One species is known to be markedly blemished.

OHIO B U C K E Y E (Esculus glabra).-A sample of bird-pecked buckeye shows a large stain, and the wound has not been closed by a year's growth. This indicates that conspicuous defects result from sapsucker work in this wood. Buckeye has not long been put to important

uses, but its easy working qualities and beauty are sure to create a greater demand for it. It is even now largely used for pyrography, for which no stained wood can be sold.

\section{THE BUCKTHORN FAMLY (RHAMNACEL).}

In the wood of two small trees of this family sapsuckers are known to produce defects varying from small dark brown stains to large stains and knotty cavities. The woods have no commercial importance.

Species of Rhamnacede Blemished.-Cascara sagrada and California lilar.

THE BASSWOON FAMILY (TILIACEF).

Defects consisting of large open checks and black stains (Pl. IX, fig. 7), due to sapsucker pecking, have been observed in the wood of 
three species of this family. They are serious in all, and either lower the grade of the lumber or spoil it for all uses except fuel.

Basswood, often called whitewood, is used for panel work, woodenware, trunks, and other purposes where whiteness is desirable. The inspection rules of the National Hardwood Lumber Association particularly note that "black spots or streaks are a serious defect and inspectors must be careful in estimating their damage. If they are excessive they will reduce the piece one or more grades." Furthermore, a great deal of basswood lumber is used for pyrographic material, in which no stains are permissible. Thus sapsucker work in basswood trees that are to be converted into lumber keeps the product out of the best grades. A loss of about 25 per cent results for each grade the lumber is reduced.

In some localities basswoods are farorite trees of the sapsuckers, as for instance on Plummers Island, Md., where three out of five are att a c ked. In Rockfish Valley, Va., also, the writer noted a large proportion of basswood bar-

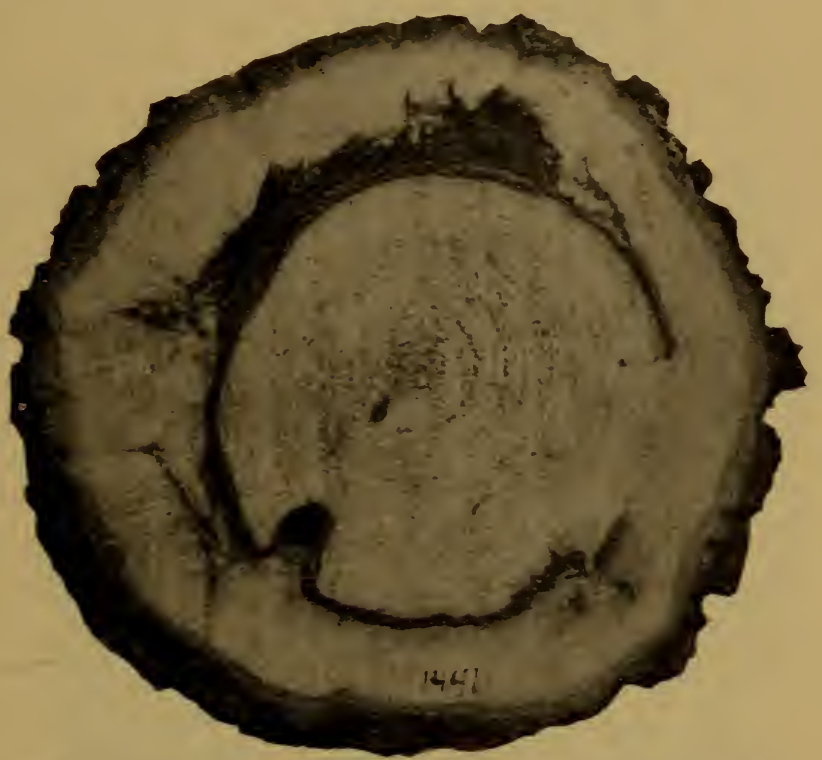

FIG. 35.-Effects of sapsucker work on wood of basswood (Tilia pubescens). Stain and extensire gaarly checks.

rel heads showing sapsucker defects. It is possible therefore that losses due to bird pecks in basswood may at times be heary.

Basswood (Tilia pubescens).-In samples from Abberille, La. (fig. 35), black stains impregnate the punctured wood ring and are so extensive as usually to be contiguous around it; ther extend an inch in each direction vertically from the wound. Large open blackstained checks result, some extending toward the bark through several annual rings. These defects are very serious and no good lumber could be sawn from a trunk so defective.

Species of Tiliace. Blemished.-Tilia americana (H. and F.) (Pl. IX, fig. 7), T. michauxii, and T. pubescens.

THE FREMONTIA FAMILY (CHEIRANTHODENDRACE.E).

The wood of the single native species (Fremontodendron californicum) is blemished by small black checks up to half an inch in length. 
THE WHITE MANGROVE FAMIL (COMBRETACE.E).

Defects due to sapsucker punctures are known in two of the three

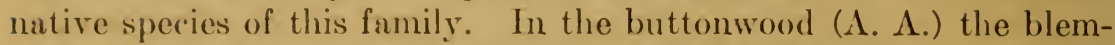
ishes are small brown to black checks with short reddish streaks in the wood. In the black olive tree the sapsucker holes are drilled deep into the sapwood, and are either healed by the intrusion of long plugs from the overlying new wood layer or remain open. These deferts may be accompanied by more or less dark stain. The wood of this tree is ralued for construction, but it is doubtful whether much loss results from bird pecks.

THE MYRTI. FAMII (MYTTACF.F).

W. Otto Emerson, of Haywards, Cal., states that the cutting of

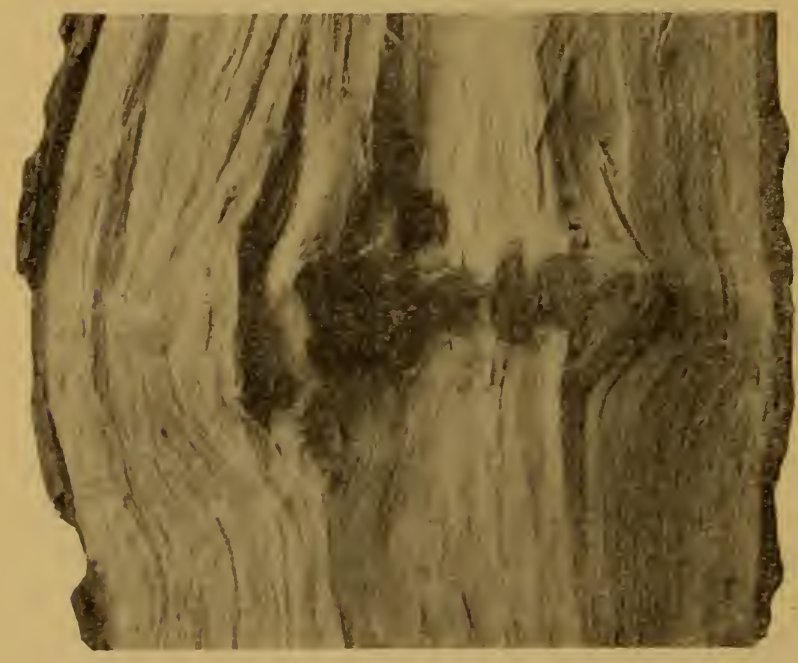

FIG. 36.-Effects of sapsucker work on wood of flowering dogwood (Cynoxylon floridum). Large stains and gnarly grain. the bark of the blue gum (Eucalyptus globulus), an introduced tree of this family, by the red-breasted sapsucker in time causes an enlargement of the limb all around and ruins the wood for commercial purposes.

THE DOG WOOD FAMILY (CORNACEE).

Blemishes produced by sapsuckers have been noted in the wood of three species of this family, in one of which, the flowering dogwood, they are very objectionable.

Flowerixg DOGWOOD (Cynoxylon floridum).-The stains are from dark reddish brown to black and are extensive, sometimes forming a continuous band half an inch wide around the ammual rings (fig. 36). The wood is strongly bent outward over the healed wood and is very gnarly. The defect: are sufficient to keep the wood out of the market, as only perfect pieces are used for such purposes as turnery, carving, and engraving. (Specimens from Cottonport, La.)

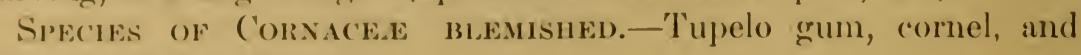
flowering dogwood. 
THE HEATH FAMILY (ERICACE.E).

The wood of two species of this family is known to be blemished by sapsuckers, the defects varying from small to very large stained checks. The woods are, however, little used.

SPECIES of Ericacez BLEMIShed.-Sourwood and madrona.

\section{THE HUCKLEBERRY}

FAMILY (VACCINIACEE).

The single native arborescent species is badly blemished by sapsuckers.

TREE HUCKLEBERRY (Batodendron arboreum).-A moderate amount of sapsucker work in this wood results in very dark brown stains, which run far along the grain and in open checks up to an inch in length. Under vigorous sapsucker attack patches of bark are killed, and the healing being slow the exterior of the tree is considerably distorted by swollen girdles and disfigured by pits and exposed patches of deadwood or bark. The wounds are marked by deep black stains or often by

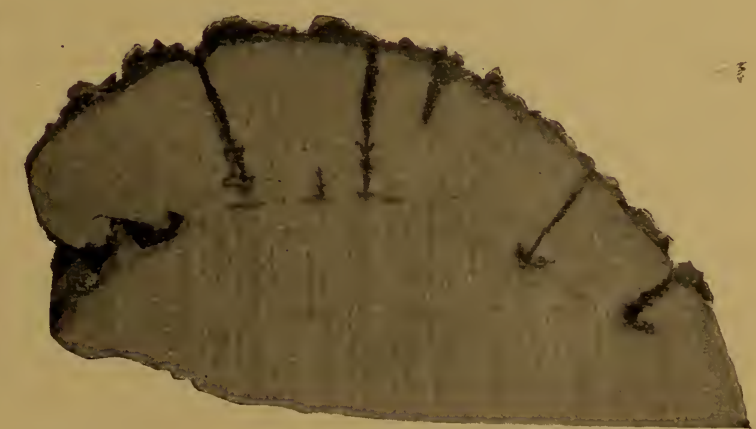

FIG. 37.-Effects of sapsucker work on wood of the tree huckleberry (Batodendron arboreum). Longitudinal and cross sections. Stained open checks and fissures.

open checks. The latter extend toward the bark and many of them have remained 10 years unhealed (fig. 37). These checks are softwalled, irregular, and black-stained, and the unclosed ones show patches of dead and discolored wood or bark up to $2 \frac{1}{2}$ inches in diameter. These blemishes make the wood useless for any but the coarsest construction or for fuel. (Specimens from Cottonport and Longbridge, La.) 
THE SAPODILLA FAMILY (SAPOTACEA).

The wood of two species of this family, the southern and Arizona buckthorns, is known to be affected by sapsucker work. The checks aresmall and round and much curled grain overlies the healed wounds; hence the effect is to embellish the wood.

\section{THE EBONY FAMHLY (EBENACEL).}

One of the two native trees of this family is known to be blemished by sapsuckers. 'The defects in persimmon are oblong deep black stains, not extending along the grain. They mar the appearance of the wood, but do not injure it for its ordinary commercial uses (Cottonport, La.).

THE OLIVE FAMII,Y (OLEACEE).

Defects due to sapsuckers have been observed in three species of this family, one of which is the unutilized devilwood, the other two being ashes, both valuable timber trees.

Some of the original wounds in ash persist as cavities only partly filled with loose woody tissue surrounded by conspicuous stains. These blemishes would lower the grade of ash wood, as it is especially prized for its usual freedom from blemishes. In ash lumber used for vehicles and for wooden parts of agricultural implements and machinery, strength is the prime requisite; but for such purposes pieces containing the small open knots resulting from sapsucker work would have to be discarded. Ash is used also for paneling and ornamental purposes. Both blemishes and ornaments appear in the samples examined, but the presence of a few small ornaments by no means prevents the rejection or degrading of a piece for defects. Occurring together, as they always do, the blemishes, which we do not want, overbalance the ornaments, which we can do without.

Winte asi (Fraxinus americana).-The defects in a specimen from Cottonport, La., are knotty checks surrounded by oblong brown stains. Lighter stains extend along the grain 6 inches or more. Curled grain and bird's-eye are abundant, but being associated with the defects have no importance. In samples of white ash from Abbeville, La., the stains tend to be continuous around the annual rings and penetrate one or two wood layers both over and under the wounded one. More or less open checks remain, some containing loose woody tissue, and the surrounding wood is quite gnarled. These defects are objectionable from an ornamental standpoint and also as to strength in the case of small pieces.

Two specimens of shovel handles are at hand showing the appearance of sapsucker defects in articles manufactured of white ash. One, obtained at Evansville, Ind. (II.), shows scars left by seven of a 
series of sapsucker pecks. The bird eridently had drilled through one and in places two layers of sapwood, and the resulting carities were partly filled by invaginations of wood from the succeeding annual ring. Each of these invaginated plugs is split and gnarly. The wood surrounding the partly filled holes is stained through from two to four annual rings. The other handle, from Marion, Ind., contains small black slightly open checks with light stains extending some distance along the grain. Only checks are present, but the handle had been placed in the lowest grade.

Species OF Oleacez Blemished.-Black ash, white ash, and devilwood (A. A.).

THE TRUMPET CREEPER FAMILY (BIGNONIACEE).

Two trees of this family are slightly blemished by small brown stains and checks due to sapsucker pecking, but the injury is probably of no economic importance.

Species of Bignoniacex Blemished.-Hardy catalpa (A. A. and A. M.) and desert willow.

THE HONEYSUCKLE FAMILY (CAPRIFOLIACEA).

Blemishes varying from small black checks to large open knotty black carities due to sapsuckers hare been noted in the wood of two trees of this family.

SPeCies of CaPRifoliaCex Blemished.-Viburnum lentago (A. A.) and $V$. prunifolium.

\section{SUMMARY OF BLEMISHES AND ORNAMENTAL EFFECTS IN LUMBER RESULTING FROM SAPSUCKER WORK.}

The embellishments, sapsucker bird's-eye and curly grain, present to some extent in practically all the wood samples described, while attractive and possibly arailable for use on a small scale, are usually not marked enough to be of commercial importance. Furthermore, they are invariably accompanied by defects which in most cases rob them of practical value and frequently so disfigure or weaken the wood as to lower seriously or eren destroy its market ralue.

It has been shown that sapsucker work unfits for use such important ornamental woods as mahogany, black walnut, white oak, yellow poplar (Liriodendron), chestnut, cherry, sweet gum, and hard maple; that it seriously blemishes woods prized for particular qualities, such as ash, basswoed, red cedar, holly, buckeye, dogwood, and hickory, in the case of the latter causing an annual loss of more than half a million dollars; and that sapsucker work sometimes destroys the value of wood even for heavy construction, as in southern basswood, Engelmann spruce, and western hemlock. In all, defects due to sapsucker work have been found in the wood of 174 species of trees. 
In 90 of these they are so serious as to spoil the appearance or workability of the wood, and in 22 species they render the wood useless except for coarse construction or for fuel.

Except in the case of hickory, there are not at hand sufficient data to determine the proportion of trees injured by sapsuckers, and hence it is not possible to estimate the actual loss. To remedy this defect in part, the writer has male inventories of the trees of certain areas. Near the mouth of Scotts Run, Fairfax C'ounty, Va., an area was marked out and found to contain 55 trees. Ten of these, or 18.1 per cent of the whole number, showed sapsucker work. Of 266 trees on a part of Plummer's Island, Md., 36, or 13.5 per cent, have been atiacked hy sapsuckers. In the west half of the Department of Agriculture grounds at Washington are 232 trees, of which 56 , or 24 per cent of the whole, show silpsucker work. The results of less definite observations in the field are as follows: On St. Vincent Island, Fla., only enough live oaks and longrleaf pines are pecked to make 1 per cent of the whole number of trees, but at the Santee (lub, South C'arolina, 90 per cent of these two species are attacked, as also enough other trees to make the proportion of the whole well over 50 per cent. At Abbeville, La., and Gainesville, Fla., 25 to 60 per cent of the trees in various forests are punctured; at Cottonport, La., about 60 per cent show plentiful pecking, and at Longbridge, Isi., fully 95 per cent of the trees are profusely drilled, there being only one species, the tupelo gum, on which no pecks were seen. In connection with these estimates it must be borne in mind that we get a record only of the trees which bear consiclerable sapsucker work, as those with only a few pecks are likely to be unnoted.

In collections of wood specimens in museums, where few if any cases of sapsucker work were overlooked, the following proportions of punctured specimens were noted: One hundred and fifty-one out of a total of about 500 , or 30 per cent of those in the American Museum of Natural History, and 71 out of about the same number, or 14 per cent of the specimens in the Arnold Arboretum, Jamaica Plain, Mass, which are mainly smaller pieces of the troes at the American Museum. The difference in size of the samples probably accounts for the discrepancy in the number bearing punctures. The collection of Illinois woods in the Field Museum of Natural History, ('hicugo, is composed of 197 pieces, of which 36 , or 18 per cent, bear supsucker work. Sixteen out of 64 , or 25 per cent, of other United States woods in the samo museum were pecked. In the writer's opinion it is safe to assume that at least 10 per cent of the trees in the normal range of the yellow-bellied woolpecker bear marks of its work. This means that the wood of 10 per eent of the trees contains defects.

1t has been shown that much white-oak and yellow-poplar veneer and many ash and hickory handles are releginted to the cull grade on acrount of hird pecks. In hundreds of barrels insperted by the 
writer in Virginia about 10 per cent of the basswood barrel heads and of the oak staves bore defects sufficient to cause their rejection from the much more valuable furniture or tight cooperage grades. It has been shown, furthermore, that from 16 to 39 per cent of the wood of individual trees, of bald cypress at least, is spoiled by defects due to sapsucker work. Howerer, if only 1 per cent of the lumber of trees attacked (10 per cent of the whole number) is discarded, the annual loss for the whole United States is more than a million and a quarter dollars. It seems certain that this estimate is not excessive, since it takes no account of lumber not rejected but recluced in grade, and since it has practically been demonstrated that the loss on one kind of timber alone, namely hickory, is fully half the sum mentioned. The meaning of these figures will be better understood if one considers that they express the ralue of fire-sevenths the total cut of black walnut in the United States, or rery near the value of the total lumber, lath, and shingle production of single States, as Arizona, Colorado, or New Mexico, and considerably more than the ralue of the lumber produced by any one of nine other States in the Union. ${ }^{1}$

\section{DO OTHER SPECIES OF WOODPECKERS SHARE THE SAPSUCKERS' HABITS?}

It has always been a mooted question to what extent, if any, other species of woodpeckers tap trees for the sap. Apparently the redheaded woodpecker is occasionally guilty of the act, but cases where it has been detected actually drilling the holes are so few that the habit must be considered exceptional. Mr. C. A. White writes as follows:

Upon the Iowa University campus we have a number of grand old aboriginal oaks, a favorite resort for red-headed roodpeckers (Melanerpes erythrocephalus). Among the young and growing trees that have been transplanted upon the campus are some sugar maples (Acer saccharinum) the bodies of which are 6 to $S$ inches in diameter. Seeing the woodpeckers busily tapping upon them, I examined the trunks and found them periectly sound, but the birds had pierced many holes of the usual size through the bark and into the cambium layer, where they stopped. The sap was flowing freely from the holes, and. watching the movements of the birds aiterwards upon the trees, I became convinced that they were sucking the sap and that they had pecked the holes for the purpose of obtaining it. ${ }^{2}$

A western relative of the red-headed woodpecker has been found doing similar work. Mr. F. Stephens makes the following statement in regard to the California woodpecker (Melanerpes f. bairdi):

At one of my camps in the pine region of Smiths Mountain, a family of this species developed the sapsucking habit. I had noticed some fresh holes in the bark of two live oaks, a foot or two from the ground, from which sap was flowing. and later I saw the birds drinking-in one case three were seen drinking at the same time. This is the only instance of the habit in this species that has come under my observation. ${ }^{3}$ 
Joseph Grinnell records the following observation upon the same species of woodpecker:

At Seven Oaks, June 24, 1906, we had been watching a Sierra sapsucker (Sphyrapicus $v$. daggetti) industriously running a line of bark pits around the branch of an alder, when a California woolpecker ... flew down and drove of the sapsucker ... then went the rounds of the borings himself, "dipping" from each."

This observation suggests that the other records of species of woodpeckers besides sapsuckers tapping trees should refer only to their purloining sap from punctures made by the latter. Be that as it may, the assertion has frequently been made that some of our woodpeckers, notably the downy and the hairy, mark trees in a fashion almost indistinguishable from that of the sapsucker. Some of the

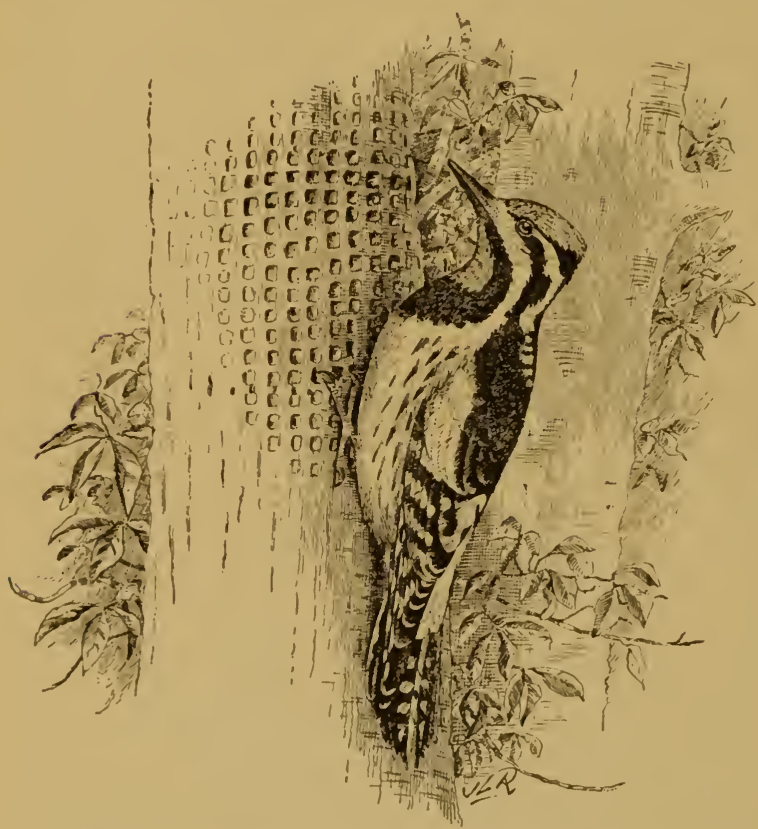

FIG. 38.-Yellow-bellied sapsucker. Note the black spot on breast.

European woodpeckers very closely related to our species of the genus Dryobates do a great deal of similar work, even producing large swollen girdles on trees, ${ }^{2}$ and it would be surprising if our species were found to be entirely innocent of such practices. Mr. Henry Bryant, of Boston, published the following testimony in 1866 :

It has long been known that some of our smaller woodpeckers pick out portions of the sound bark of trees, particularly of apple trees, where there are no They [the pecks] are larvie and apparently no inducement for them to do so. generally seen in circles round the limbs or trunks of small irregularly rounded holes, and in this vicinity are made almost exclusively by the downy woodpecker, I. pubescens, aided occasionally by the hairy woodpecker, P. villosus. ${ }^{3}$

Dr. J. A. Allen corroborates these statements as follows:

The perforations made in the bark of trees by woodpeckers, forming transverse rings, and sometimes so numerous as to do serious injury to the trees, have of late been very (ommonly attributed almost solely to this species [yellow-bellied woolpecker]. especially at the West, where it is so numerous. That it is, from this habit, often greatly injurious to fruit trees is not to be denied; but that this species-now commonly styled the "true sapsucker," to whose clepredations it is sail should be assigned the

2 See Fuchs, Gillert. Üher das laingeln der spechte und ihr Verhaltengegen die kleineren Forstschädlinge. Naturwise. Zeitschr. f. Lamd u. Forstwirtschaft, 111, 317-341, 1905.

'J'rox. Bost. Soc. Niat. Hist., X, 91-2, 1siki. 
general ill repute attached to the whole family by most agriculturists-is the sole author of this work, which so often amounts to mischief, there is abundant evidence to disprove. In most parts of Massachusetts, particularly in the Connecticut Valley, this species is so extremely rare that $\mathrm{I}$ have never seen more than half a dozen specimens in a year, and oftener none at all, and then always during its migrations; while other expert collectors have searched for it unsuccessfully for years; yet our orchards always present these perforations in profusion, though seldom to an injurious degree: and now and then a forest tree is observed so thoroughly girdled as to be thus destroyed. For this our spotted woodpeckers, Picus pubescens and P. villosus, are chargeable. being in many sections the sole authors of it; they may be, in fact, very often seen engaged in it. I do not, however, suppose their object to be the same as that assigned to the Sphyrapicus varius-that of sucking sap or feeding on the inner bark. ${ }^{1}$

Evidence supporting the same contention is given by Mr. C. K. Reed, who says:

Iost of you have probably noticed apple trees that had rows of holes extending around, or nearly around, the trunk. I was always told, and frequently see it in print now, that these were made by sapsuckers. Perhaps some of them are, but not all. Last fall I watched a downy busily at work hammering on the trunk of an apple tree. $\mathrm{He}$ would pound away for about half a minute steadily in one spot and then hitch sideways about an inch and repeat the operation; when he had completely encircled the tree he dropped down about his length and made another ring around the trunk. The marks left on the tree were identical with those that I had supposed were made by

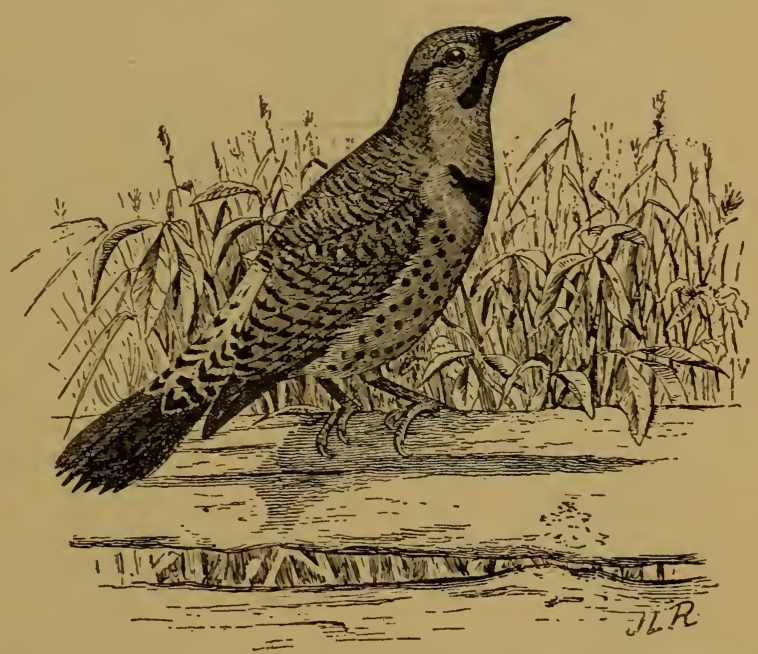

FIG. 39.-Flicker. Not a sapsucker. Has black spot on breast, but top of head from bill is not red. Has conspicuous white rump.

the sapsuckers. The downy did not appear to find anything to eat, and I concluded that he was doing it in play or that he wished to sharpen his bill."

There is one fallacy included or implied in most of the above quotations, namely, that a profusion of punctures in trees where the sapsuckers are scarce proves that the work was done by other woodpeckers. This by no means follows. In most cases the bulk of the pecking on trees is old; only a moderate number of punctures, as a rule, are made each year, and the amount of fresh work rather than the total should be considered in determining the probable agent. A tree 100 years old-a moderate age-might bear much sapsucker work, even where the birds are very scarce and only a few holes were drilled in it each year. When a great number of punctures are made 
in one season, the tree is likely to be weakened or killed, and not a single instance is on record of any woodpecker in this country, other than a member of the genus Sphyrapicus, killing a tree by girdling it. Nor, as a rule, is the work of the hairy and downy woodpecker so much like that of the sapsuckers as not to be distinguishable from it. The writer has observed the downy woodpecker at work in suspicious proximity to fresh drills resembling those made by sapsuckers. But upon examination these were found to go barely through the outer bark and not to the sapwood, as is true of sapsucker holes. Hence

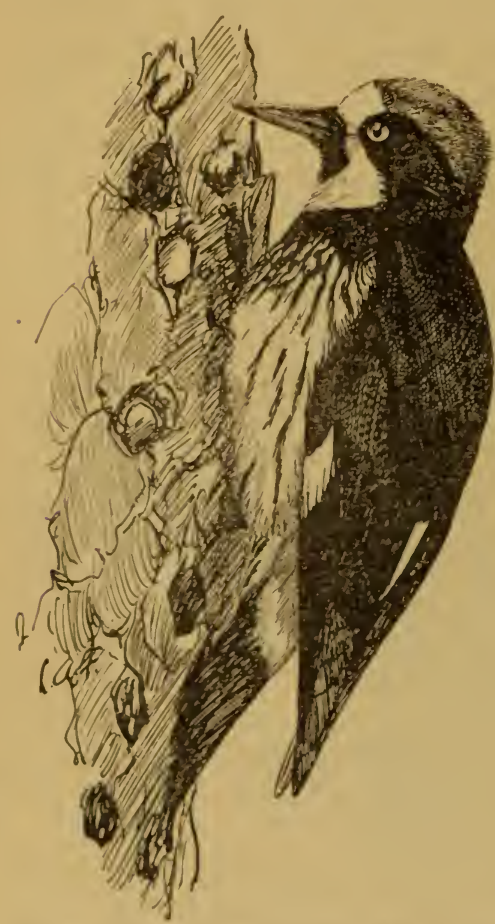

F1G. 40.-California woodpecker. Not a sapsucker. Has black breast spot, but head is not red from base of bill. the punctures were not injurious. Mr. E. H. Forbush notes ${ }^{1}$ that the perforations made by the downy [in red maple] differ from those of the sapsucker; and Weed and Dearborn seem to have had similar experience, as they say of the downy woodpecker: "Although it bores holes in the bark of apple trees, it does not revisit them to suck the sap... and the holes seem usually not to injure the tree." ${ }_{2}$ Prof. F. E. I. Beal corroborates this, saying that the holes made by this woodpecker reach only to the inner bark and that no protruding girdles or other deformations of the trunk are produced.

$\Lambda$ very convincing bit of evidence bearing on this point is given by Dr. T. M. Brewer. He had experience in parts of the country where the sapsucker is not often seen, but where there are many punctured trees, conditions which cause the downy, hairy, and other woodpeckers to be known as sapsuckers and to be persecuted. Upon becoming well acquainted with Sphyrapicus also, he wrote as follows:

In $\Lambda$ pril, 1s68, I visited gardens in Racine, in company with Dr. Hoy, where these woulpeckers [i. e., sipsuckers] had every successive spring committed their ravages, and was eyewitness to their performance. Their punctures were unlike those of pulusecns (downy), being much dreper, penetrating the inner bark, and being repeated in close proxinity. . . of ofen resulting in the girdling and complete destruction of a tree. In one garden of some considerable size all the mountain ash and white pine 
trees had thus been killed. In prairie countries, where trees are a deficiency and their cultivation both important and attended with difficulty, these birds prove a great pest, and in a few hours may destroy the labor of many years. ${ }^{1}$

Whether or not the downy and other woodpeckers seek sap, it is beyond question that they are not important consumers of cambium, since on the average much less than 1 per cent of this substance has been found in the stomach contents of any other woodpecker than the true sapsuckers (Sphyrapicus). ${ }^{2}$ It is the loss of cambium rather than of sap that breaks down the vigor of the trees and is responsible for defects in the wood, and to the sapsuckers, which consume cambium to an average extent of 13.8 per cent of their annual food,

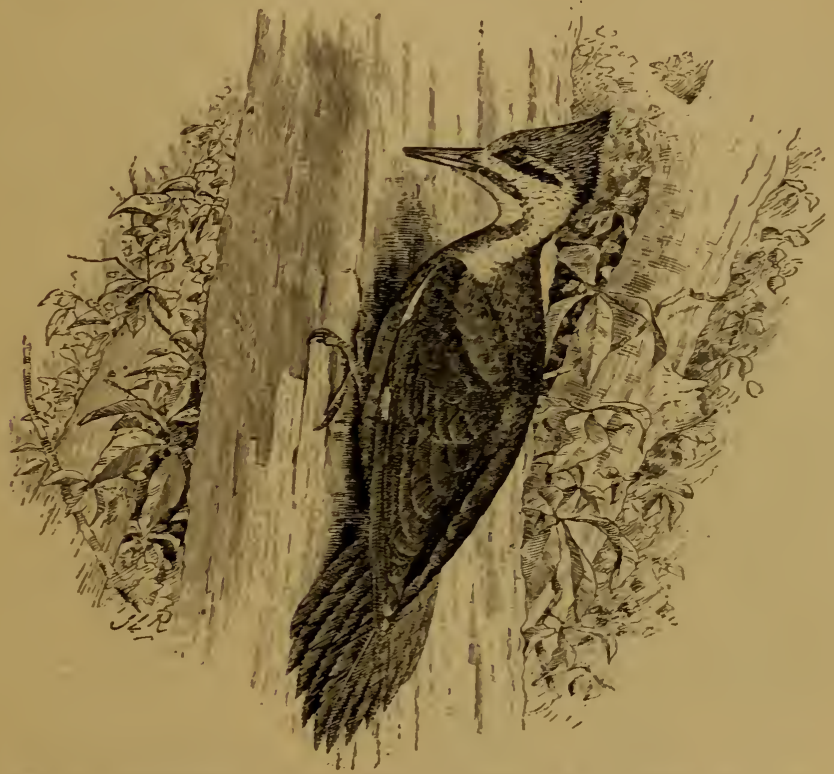

FIG. 41.-Pileated woodpecker. Not a sapsucker. Entire lower parts black.

must be attributed most if not all serious injuries to trees due to the destruction of cambium by woodpeckers.

\section{FOOD OF SAPSUCKERS.}

About four-fifths of the insect food of the three species of sapsuckers consists of ants, the eating of which may be reckoned slightly in the birds' favor. The remainder of the food is made up of beetles, wasps, and a great variety of other insects, including, however, practically no wood-boring larra or other special enemies of trees. The birds' regetable food can not be cited in their behalf, as it consists almost entirely of wild fruits, which are of no importance, and of

1 Baird, Brewer, and Ridgway, History of X. A. Birds, Land Birds, II, 542,1874 .

2 A mere glance at the figures ( 3 and 4 ) of the tongues of the yellow-bellied sapsucker and the downy woodpecker must convince anyone that these birds are adapted to the utilization of entirely different food supplies. 
cambium, the securing of which results in serious damage, as shown in the preceding pages.

\section{HOW TO RECOGNIZE SAPSUCKERS.}

Plate I (frontispiece) and Plate II (p. 16) will serve to identify the sapsuckers better than pages of printed descriptions, and therefore only a few marked color differences will be mentioned here. All sapsuckers have yellow bellies, few other woodpeckers have; all sapsuckers have a conspicuous white patch on the upper part of the wing, as seen from the side when clinging to a tree; white wing patches in other woodpeckers are on the middle or lower part of the

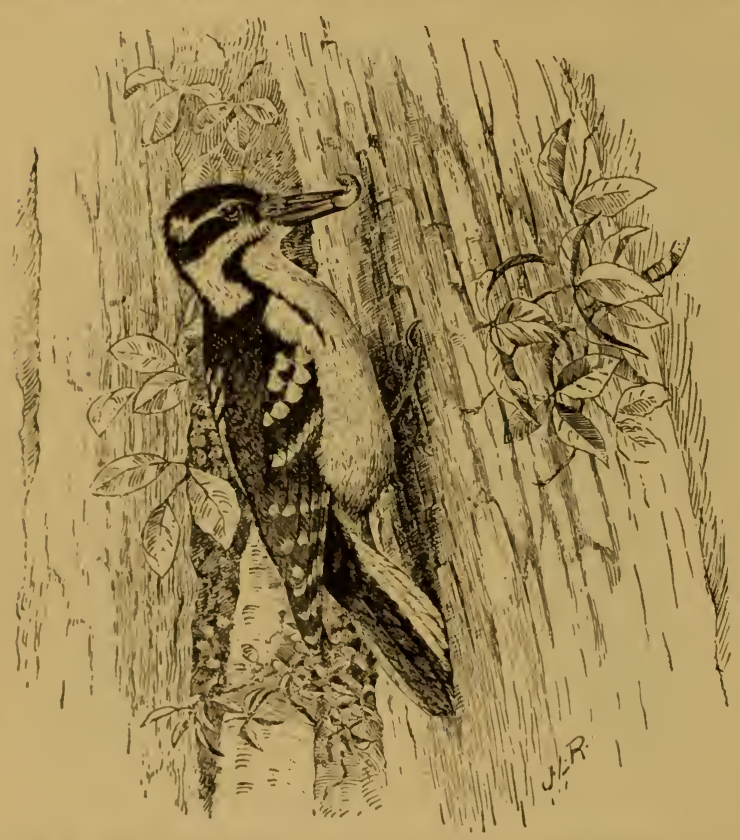

FIG. 42.-11airy woodpecker. Not a sapsucker. No black breast spot. wings. The yellowhellied sapsucker of $\mathrm{t} r$ anscontinental range is the only woodpecker having the front of the head (i. e., from bill to (rown) red in combination with a black patch on the breast. The red-breasted sapsucker lives west of the Rockies and is the only species there having the whole head and throat red.

From 4 to 11 spe('ies of woodpeckers other than sapsuckers occur in various sections of the United States; hence a majority of woodpeckers seen are not sapsuckers. Several of these species are illustrated (figs. 38 to 44), and notes are given on the features distinguishing them from sapsuckers.

\section{DEFENSIVE MEASURES AGAINST SAPSUCKERS.}

Mr. C. G. Bates says of the eastern bird:

The sapsucker spends only his winters in the hardwood region, and the greatest damage is done on warm winter days and in the spring just before migration. For this reason hickories should not be planted, especially in the South, in situations where they will be started by the first warm days, but rather where their rise of sap will be retarded. 
This advice applies to the planting of orchards also, as the risk of damage by frost is lessened by planting on north slopes. It is said that fine wire netting has been used in some localities to protect the trunks of fruit trees, but this is impracticable for large numbers of trees, while advice as to methods of planting does not apply to trees at present subject to sapsucker attack. Good results have been obtained by plastering cow droppings or fish glue around trees where the sapsuckers have worked, and the wounds may be made to heal more readily by cutting out the injured parts and covering with grafting wax.

When preventive measures fail and the extent of the damage warrants it, the birds must be killed. But such extreme measures should be adopted only when orchards or other valuable tree plantations are attacked, and extreme care should be taken to kill only the injurious species.

It does not appear to be difficult to poison. sapsuckers. Mr. Ellwood Cooper has kindly furnished details of a method of poisoning used successfully by himself in C'alifornia, of which the following is the substance: I took about one-half pint of honey and pulverized the crystals of strychnine, using about a

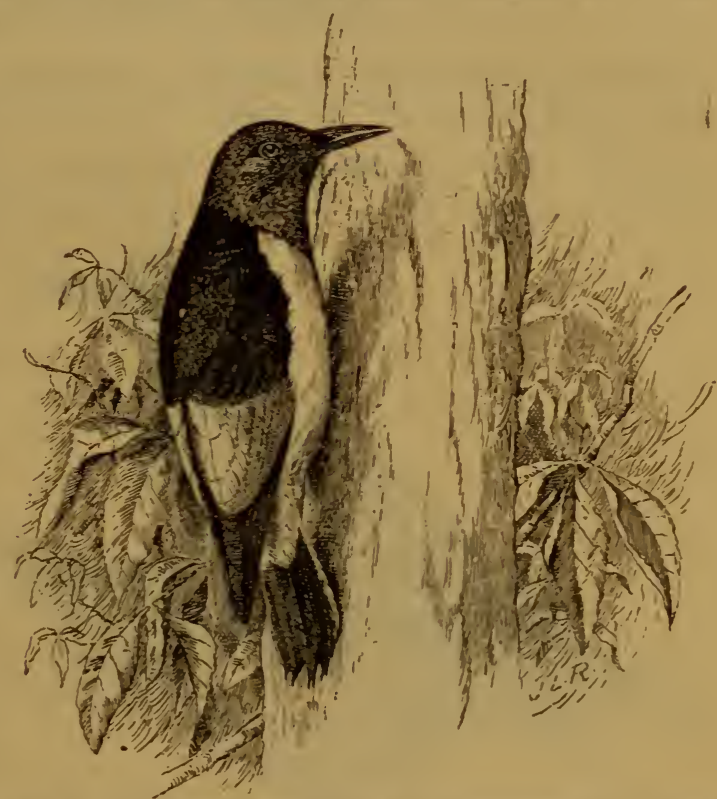

FIG. 43.-Red-headed woodpecker. Not a sapsucker. Has no black spot on breast.

coffeespoonful of the powder and making a thorough mixture. With a wooden paddle I smeared the mixture around the trunk about 2 or 3 inches above the last ring of holes made by the birds. It proved very effective. This method has the advantage of insuring the destruction of the sapsuckers, while the risk of destroying other birds is reduced to a minimum.

The method of poisoning may be stated in more exact terms as follows: Mix thoroughly an eighth of an ounce of powdered strychnine (the alkaloid, which is not easily soluble, and hence will not flaror the 99068 - Bull. 39-11—7 
mixture) with 1 pint of honey or other thick sirup. Apply to the injured tree just above the rows of fresh punctures.

A simpler way of poisoning the sapsuckers was discovered by Mr. Ned Dearborn of the Biological Survey. The powdered strychnine (alkaloid) was introluced directly into the fresh sap pits, by means of a bit of straw or grass stem. A very small quantity sufficed for each hole, and the poison remained effective for at least two days. It should be noted here that humming birds and some other small birds, particularly warblers, will be killed by poison intended for sapsuckers. Nevertheless, taking all things into consideration, it seems wise to recommend the use of poison rather than the gun.

\section{GENERAL CONCLUSIONS.}

From an economic standpoint woodpeckers may be divided into two groups:

(1) The woodpeckers proper, which are chiefly beneficial. These slightly damage trees when excarating nests and shelter cavities.

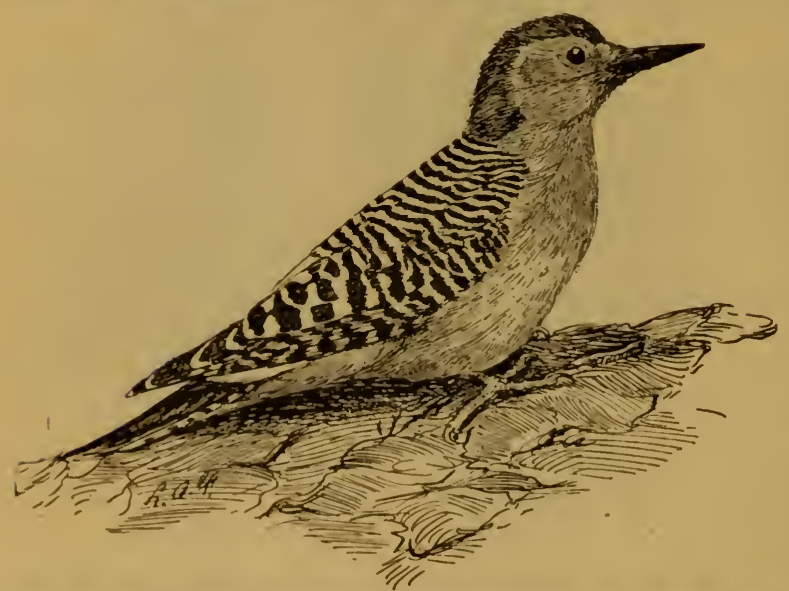

FIg. 44.-Red-bellied woodpecker. Not a sapsucker. No black breast spot.

In some sections they are responsible also for injury to telephone and telegraph poles and for minor damage to houses, barns, fences, and other structures. To minimize this damage the trial of nesting boxes especially designed for woodpeckers is re c om mended. Killing the birds should be the last resort. When all is said and done, however, woodpeckers of this group much more than compensate for all the harm they do by levouring large numbers of the insect enemies of trees, many of which are preyed on by no other birds.

(2) Sapsuckers, which are very injurious. The sapsuckers, unlike other woodpeckers, secure a considerable part of their subsistence from the tissues and juices of trees. In doing this they often destroy so much of the cambium or growing layer that the trees are weakened and disfigured or even killed. Further, the wood of many of the trees they attack is so stained and distorted during the healing process that its value for lumber is impaired or destroyed. The loss 
from this cause in the United States is more than one and a quarter million dollars annually. Sapsuckers do not prey upon any especially destructive insects and do comparatively little to offset the damage they inflict. Hence the yellow-bellied sapsucker (Sphyrapicus varius) and its western rariety (Sphyrapicus $v$. nuchalis), the red-breasted sapsucker (Sphyrapicus ruber) and its northern form (Sphyrapicus $r$. notkensis) must be included in the class of injurious species, the destruction of which when caught red-handed is justifiable. In certain States it may prove desirable to deny these birds the degree of protection they now enjoy. We know too little at present to decide the status of the Williamson sapsucker (Sphyrapicus thyroideus).

As there are 20 species of woodpeckers in the United States and onl 2 of them are under indictment, great care should be exercised to distinguish the real offenders. When it is necessary to destroy sapsuckers, poison should be used because of the small risk to other species of birds.

\section{O}


UNIVERSITY OF FLORIDA

|||||||||||||||||||||||||||||||||||||||||||||||||||||||||||||||

31262084916948 